\title{
Stonewall Jackson Resort Master Plan: An ecological model for stormwater management that engages and educates through context sensitive low-impact development strategies
}

Claire E. Jeran

West Virginia University

Follow this and additional works at: https://researchrepository.wvu.edu/etd

\section{Recommended Citation}

Jeran, Claire E., "Stonewall Jackson Resort Master Plan: An ecological model for stormwater management that engages and educates through context sensitive low-impact development strategies" (2013). Graduate Theses, Dissertations, and Problem Reports. 3389.

https://researchrepository.wvu.edu/etd/3389

This Thesis is protected by copyright and/or related rights. It has been brought to you by the The Research Repository @ WVU with permission from the rights-holder(s). You are free to use this Thesis in any way that is permitted by the copyright and related rights legislation that applies to your use. For other uses you must obtain permission from the rights-holder(s) directly, unless additional rights are indicated by a Creative Commons license in the record and/ or on the work itself. This Thesis has been accepted for inclusion in WVU Graduate Theses, Dissertations, and Problem Reports collection by an authorized administrator of The Research Repository @ WVU. For more information, please contact researchrepository@mail.wvu.edu. 


\title{
Stonewall Jackson Resort Master Plan: An ecological model for stormwater management that engages and educates through context sensitive low-impact development strategies
}

\author{
by \\ Claire E. Jeran \\ Thesis submitted to the \\ Davis College of Agriculture, Natural Resources and Design \\ at West Virginia University \\ in partial fulfillment of the requirements for the degree of \\ Master of Landscape Architecture \\ In \\ Landscape Architecture
}

Approved by

Peter Butler, MLA, Chair

Angela Campbell, MLA

Nicolas Zegre, Ph.D.

Department of Landscape Architecture Program, Division of Resource Management

\author{
Morgantown, West Virginia \\ 2013
}

Keywords: landscape architecture; state park development; sustainability; West Virginia Copyright 2013 Claire E. Jeran 


\title{
ABSTRACT \\ Stonewall Jackson Resort Master Plan: An ecological model for stormwater management that engages and educates through context sensitive low-impact development strategies
}

\author{
by Claire E. Jeran
}

Stonewall Jackson Lake State Park sits in central West Virginia in the heart of the Appalachian Mountains. The dammed lake and state park opened to the public over two decades ago and development within the property continues today. The attention to stormwater management, vegetation, and public awareness of their connection to the natural environment become an integral component to an ecologically sustainable landscape. This project focuses on the eighteen acres surrounding the lodge buildings on a lakefront peninsula. The design responded to a thorough analysis and seeks to enhance the visitor's experience through use of new program elements, circulation patterns, vegetation, and stormwater management. Educational and interpretive opportunities considering stormwater management, native vegetation communities, and diverse habitats create a laboratory environment for visitors and state park programs. Stormwater management systems are designed using the Chesapeake Stormwater Network and the Environmental Protection Agency (EPA) methods. Renderings support the explanations of each space throughout the site, completing the picture of the proposed designs. 


\section{DEDICATION}

The author wishes to dedicate this thesis project to her supportive committee members, family, and friends for their continual encouragement and loving care. 


\section{ACKNOWLEDGEMENTS}

The author wishes to acknowledge the following people for their time, advice, knowledge, criticism and support as a way of making this project a success:

from West Virginia University:

Peter Butler

Angela Campbell

Adam Riley

Nicolas Zegre

from Stonewall Jackson Lake State Park:

Chad Clovis

Sam England

Mike Hager

Jay Hayes

Rudy Henley

Samantha Norris

Robin Poling

OHM Advisors

Joe Kidd 


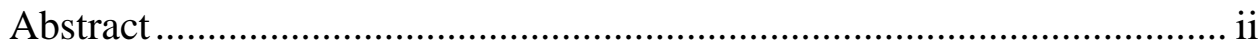

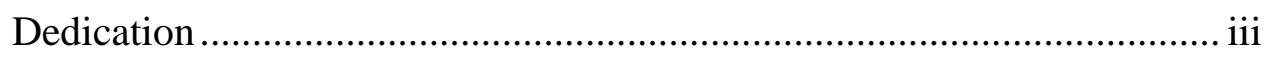

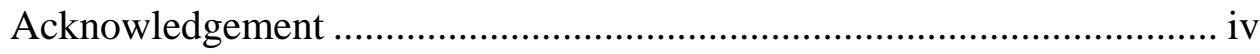

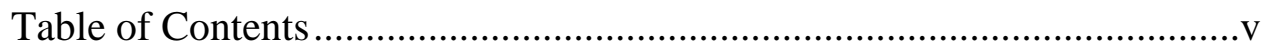

LIST OF FIGURES ................................................................... vi

LIST OF TABLES ....................................................................... viii

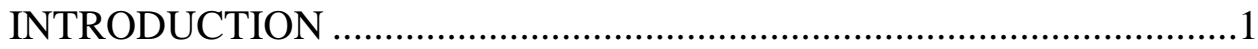

CHAPTER 1: Defining the Problem........................................................6

CHAPTER 2: Literature Review .......................................................

CHAPTER 3: Design Process and Methodology ...................................13

CHAPTER 4: Cultural Inventory and Analysis.....................................19

CHAPTER 5: Vegetation and Wildlife Inventory and Analysis ..............26

CHAPTER 6: Physical Inventory and Analysis ....................................30

CHAPTER 7: Soil Inventory and Analysis ..........................................36

CHAPTER 8: Hydrology Inventory and Analysis..................................38

CHAPTER 9: Composite Analysis ....................................................41

CHAPTER 10: Program Development................................................43

CHAPTER 11: Stormwater Management..............................................51

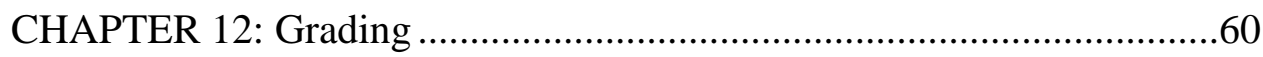

CHAPTER 13: Vegetation............................................................63

CHAPTER 14: Master Plan and Design Descriptions.............................70

CHAPTER 15: Materials ...............................................................101

CHAPTER 16: Construction Documents .............................................103

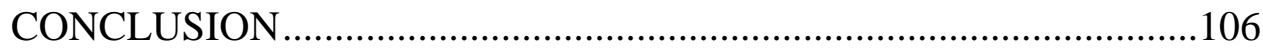

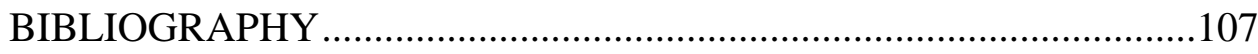




\section{LIST OF FIGURES}

Figure 1. Statewide Context Map …......................................................

Figure 2. Roanoke Map........................................................................2

Figure 3. Stonewall Jackson Lake State Properties ................................... 3

Figure 4. 1939 Site Aerial Image .........................................................21

Figure 5. 2009 Site Aerial Image ...........................................................22

Figure 6. 1939 and 2009 Image Overlay .............................................23

Figure 7. USGS GAP Land Cover Map ...............................................27

Figure 8. Existing Vegetation Area ........................................................28

Figure 9. Stonewall Jackson Lake State Park Map..................................30

Figure 10. Existing Site Amenities .......................................................32

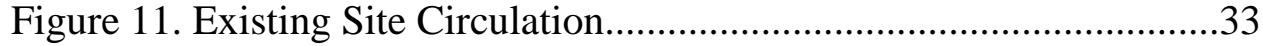

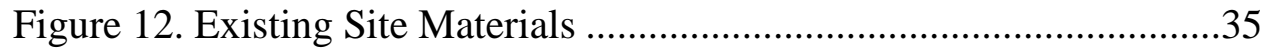

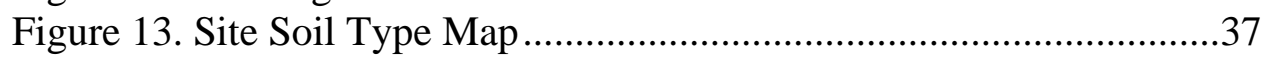

Figure 14. Site Slope Map .................................................................38

Figure 15. Drainage Inventory Map....................................................39

Figure 16. Hydrology Analysis Map ...................................................40

Figure 17. Composite Analysis Map ...................................................42

Figure 18. Stakeholder's Program Map .................................................44

Figure 19. Pedestrian Circulation Map .................................................45

Figure 20. Additional Program Map.......................................................47

Figure 21. Stormwater Management Possibilities Map...........................48

Figure 22. Program Overlay Map ........................................................49

Figure 23. Parking Lot Bioretention Cross-Section..................................53

Figure 24. Bioretention Subwatershed Delineation Map..........................54

Figure 25. Designed Bioretention Cells Map .........................................54

Figure 26. Typical Streetscape Enhancement.........................................55

Figure 27. Designed Bioswales Map ..................................................56

Figure 28. Bioswale Cross-Section.....................................................5

Figure 29. Enhanced Wetland Design ....................................................58

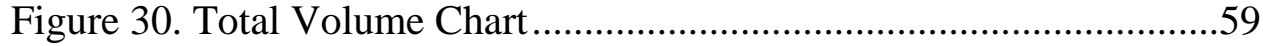

Figure 31. Enhanced Wetland Elements ..................................................59

Figure 32. Enhanced Wetland Cross-Section .........................................60

Figure 33. Designed Path Map............................................................61

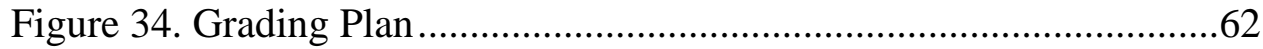

Figure 35. Seed Mix Zones ................................................................64

Figure 36. Seed Mix Cross-Section ........................................................64

Figure 37. Site Master Plan................................................................... 71

Figure 38. Entrance Allee ...............................................................72

Figure 39. Reference to Figures 38, 40 ............................................73

Figure 40. Entrance Allee Cross-Section ...............................................73

Figure 41. Parking Lot Artery...............................................................74

Figure 42. Reference to Figures 41, 43.............................................. 74

Figure 43. Parking Lot Cross-Section...................................................75

Figure 44. Red Maple Circle..............................................................76

Figure 45. Reference to Figure 44 .....................................................76 


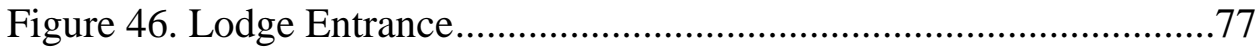

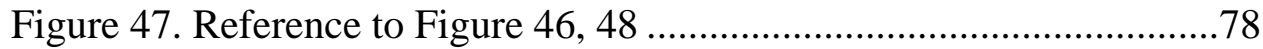

Figure 48. Lodge Entrance Cross-Section .................................................78

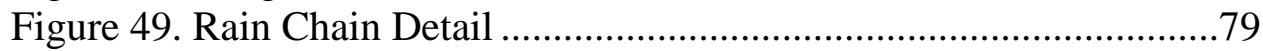

Figure 50. South Lawn...................................................................8

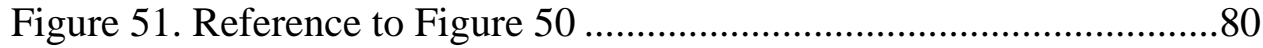

Figure 52. Detached Downspout Detail...............................................81

Figure 53. Rear Lodge Path .............................................................82

Figure 54. Reference to Figures 53, 55...............................................82

Figure 55. Northern Lodge Path ........................................................83

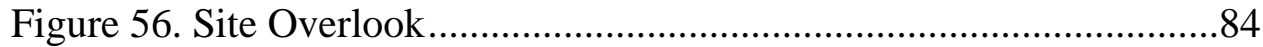

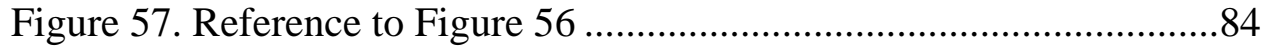

Figure 58. White Tail Nature Play Area Cross-Section............................85

Figure 59. White Tail Nature Play Area ...............................................86

Figure 60. Reference to Figures 58, 59.............................................86

Figure 61. Pin Oak Cove Picnic Area ....................................................87

Figure 62. Reference to Figures 66, 68.............................................88

Figure 63. Pin Oak Cove Picnic Area .....................................................88

Figure 64. Meadow .....................................................................89

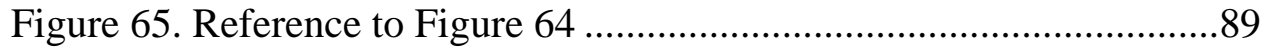

Figure 66. Wetland Exploration Area ..................................................90

Figure 67. Reference to Figures 66, 68............................................91

Figure 68. Wetland Exploration Area Cross Section..............................91

Figure 69. Forest Trail .................................................................92

Figure 70. Reference to Figures 69, 71 ............................................92

Figure 71. Forest Trail Cross-Section ..................................................93

Figure 72. Prairie ......................................................................99

Figure 73. Reference to Figures 72, 74...........................................94

Figure 74. Prairie to Lodge Cross-Section.............................................95

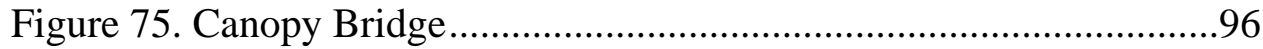

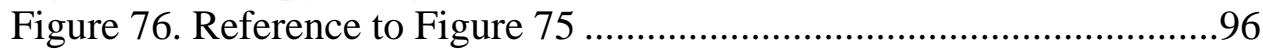

Figure 77. Roadside Entrance to Dogwood Landing..............................97

Figure 78. Reference to Figures 77, 79, 80 .........................................97

Figure 79. Dogwood Landing .............................................................98

Figure 80. Dogwood Landing Cross-Section.........................................99

Figure 81. Program Elements Implementation Graphic .........................99

Figure 82. Bioswale Stone Cascade Construction Detail .......................103

Figure 83. Deck Construction Detail .....................................................104

Figure 84. Stone Seat Wall Construction Detail......................................105

Figure 85. Bird's Eye Site Image.......................................................106

*Please note that all figures are original. 


\section{LIST OF TABLES}

Table 1. Seed Mix Descriptions...............................................................65

Table 2. Seed Mix Species List A.........................................................66

Table 3. Seed Mix Species List B ......................................................67

Table 4. Seed Mix Species List C .........................................................68 


\section{INTRODUCTION}

An eighteen acre lakeside peninsula within Stonewall Jackson Lake State Park sits in the Appalachian Mountains of Lewis County, West Virginia. Lewis County lies in the north central part of West Virginia, and is bordered by Upshur, Harrison, Doddridge, Gilmer, Braxton and Webster Counties. Interstate 79 runs directly through the county providing access from the north and south (Fig. 1). South of the county seat Weston, the former town of Roanoke was settled in the late $18^{\text {th }}$ century (Fig. 2). Roanoke rested along the West Fork River which contributed to the growth of the grist mill industry. In the early $19^{\text {th }}$ century a part of the river was dammed for the construction of a gristmill. The mill was used for the cutting of timber as well as for grinding flour and become an economic asset for the area. Unfortunately in the 1870s, the region was plagued by floods which led to the fall of the milling industry (Carlisle, 1983).

Figure 1. Statewide Context Map

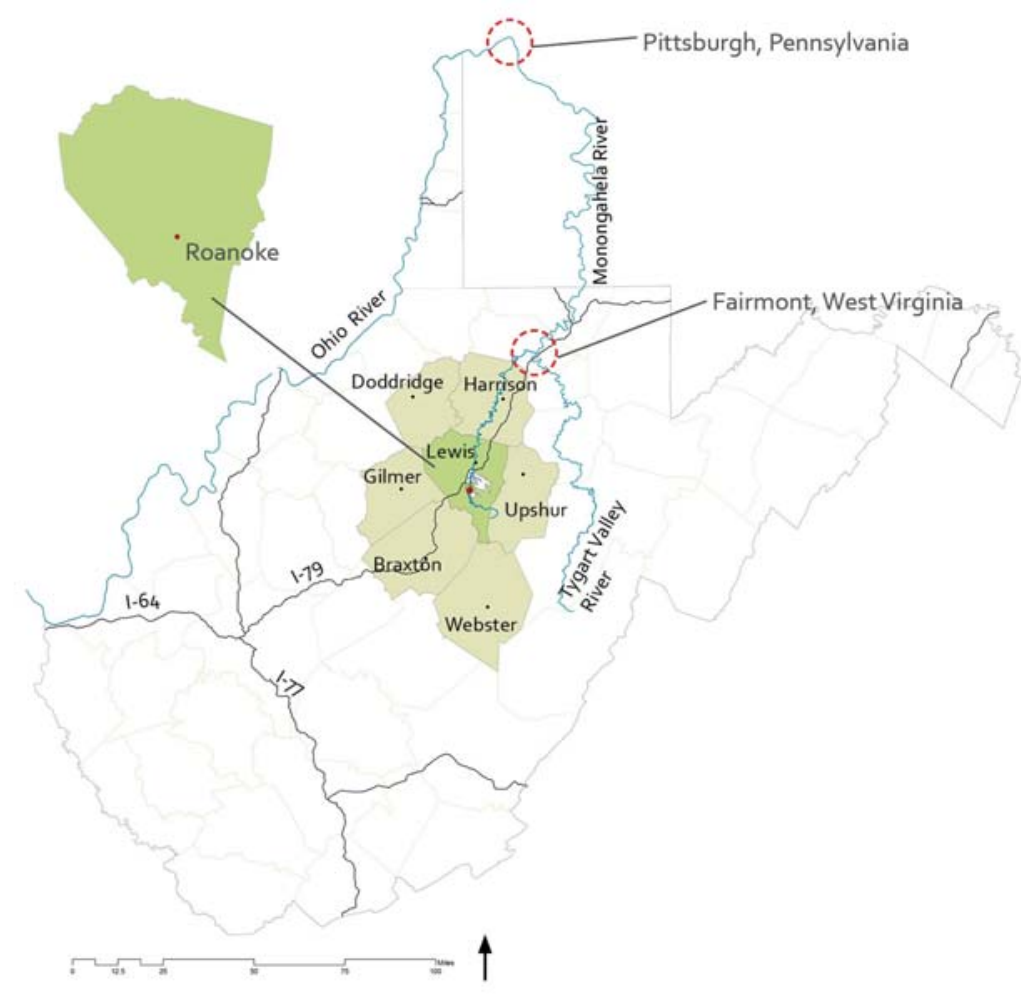


Figure 2. Roanoke Map
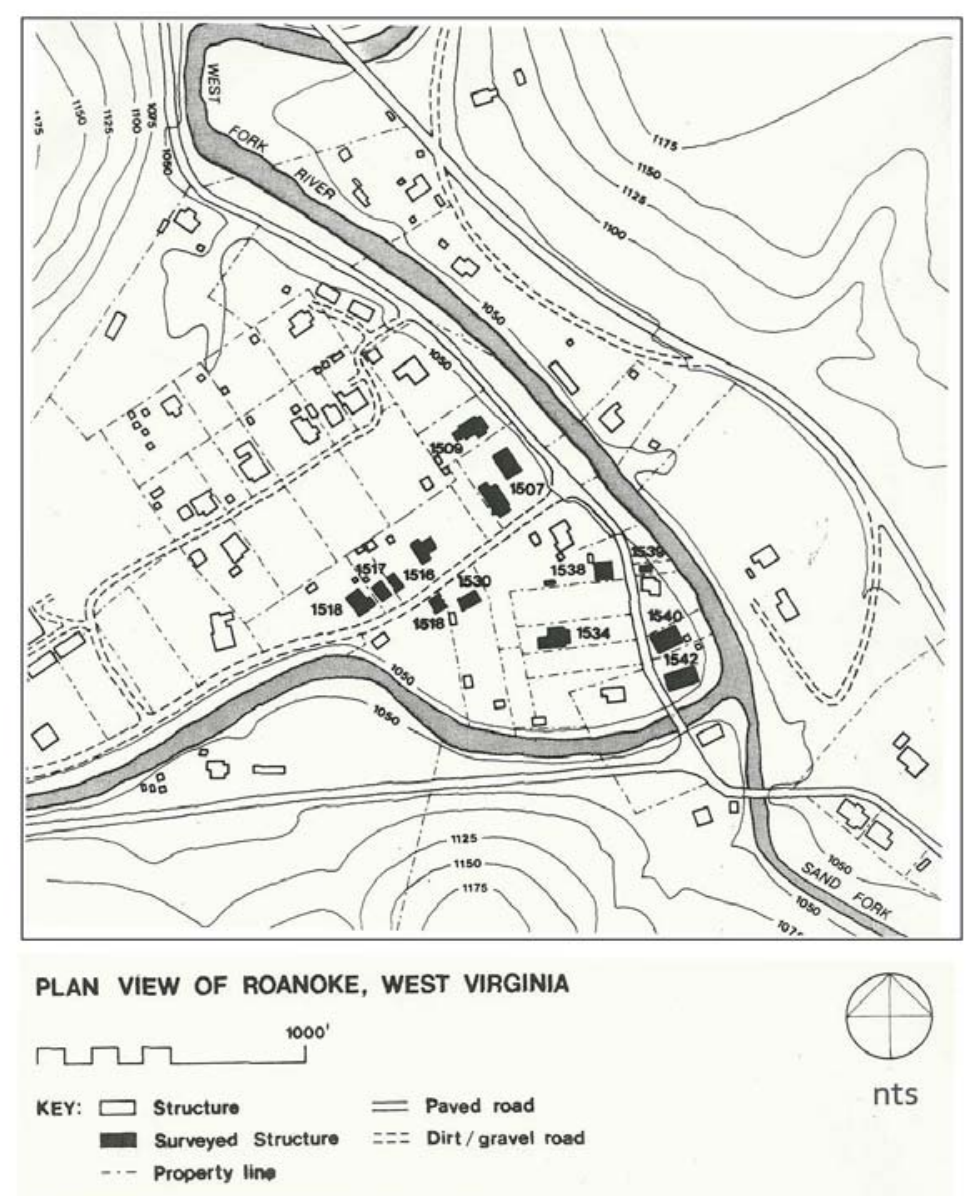

In addition to the mill industry, Roanoke became an agricultural center of the region.

The construction of the railroad in 1891 contributed to the export of cattle and turkeys. The railroad station handled thousands of head of cattle each year, shipping locally to Philadelphia and Baltimore. At the turn of the century, Lewis County ranked second in the state in cattle production; although by the mid- $20^{\text {th }}$ century few farmers could survive solely on farming due to decreased demand (Carlisle, 1983). Many residents of Roanoke commuted to Weston to find work at the glass factory, local stores or the West State Hospital. The town of Roanoke existed for the greater portion of two-hundred years, until eminent domain collected the land of Roanoke for the construction of the Stonewall Dam and Lake. 
The West Fork River flows from the southeast part of the county northward. The river forms near the community of Rock Cave in southwestern Upshur County, and it merges with the Tygart Valley River in Fairmont West Virginia, forming the Monongahela River (Carlisle, 1983). The Monongahela River meets the Allegheny River in Pittsburgh, Pennsylvania, forming the Ohio River. The low-gradient and slow-moving waters create a popular place for fishing.

The West Fork River has a history of damaging floods. Many floods damaged Weston, Clarksburg and Fairmont. On October 27, 1966 Congress passed a nationwide flood control bill, which included the \$34.5 million Stonewall Jackson Reservoir project. Officials projected the project to be completed in six years. Legal obstructions for construction of the lake developed when President Nixon signed the 1974 Water Resources Bill on March 13. A few years later on March 30, 1977, Governor Jay Rockefeller signed the agreement for recreational development of the lake by the state and federal government, giving the lake construction a positive "go" forward. The Director of Natural Resources, Dan Callahan, added his signature to the agreement, confirming the state’s approval of the project (“Dedication”, 1988).

Although the project was approved, many locals opposed the 19,500 acre land acquisition because they would lose their community rights. In 1977, the Upper West Fork River Watershed Association appealed the construction of the Stonewall Jackson Dam and Lake to the Fourth US Circuit Court of Appeals in Richmond, VA. Their appeal was declined, but their efforts did not subside. The Army Corps of Engineers held a public meeting concerning the land acquisition of the lake on June 15, 1977, where opposed land owners and members of the watershed association voiced concerns. The project faced another hurdle on April 8, 1978, at the Washington, D.C., conference on Rivers, Dams, and National Water Policy, the Coalition for Water Project Review. A list of water projects were recommended to be re-evaluated or 
immediately de-authorized. Stonewall was listed on the "needing re-evaluation 'until it meets rigorous environmental, economic, and safety criteria”" (“Dedication”, 1988). However, by January 31, 1979, the project was approved and 151 persons were relocated after their property was purchased by the US Army Corps of Engineers in the Roanoke and Stonewall area. Opponents to the project continued to fight at the WV Senate Judiciary Committee and the US Federal Court, but were still declined. On July 2, 1980, the House of Representatives approved \$15.8 million for the construction of the 90-foot-high barrier across the West Fork River. The Army Corps of Engineers awarded the contract to Weiss Brothers of McKeesport, PA for the relocation of 4.5 miles of US 19 (“Dedication”, 1988).

By the summer of 1984, the construction of the dam began with 700-900 cubic yards of concrete being poured per day. The final land owners to be removed from their property were the Heaveners. They were arrested and had to be handcuffed and physically removed. By May $29,1985,55 \%$ of the dam construction was completed. At the end of January 1988, the lake was impounded covering 2,630 acres. On May 21, 1988, a dedication ceremony was held for the completion of the Stonewall Jackson Dam (“Dedication”, 1988).

Originally, officials sought National Park Service recognition of Stonewall Jackson, but ultimately the park became a State Park and development began after the dedication in 1990 . The State Park consists of 2,650 acres with the remaining 18,289 acres comprising the Wildlife Management Area (Fig. 3). The property’s ecology consists of dominant tree cover through rolling mountains framing the lake. In 2000, construction began on the state park resort expansion including the Arnold Palmer golf course and lodge development. Ecological sustainability is now a mission of the resort, and therefore the area around the lodge becomes the project site. The site's connection to the waterways is important to establish the need for water 
quality improvement. The site also connects people to the landscape ecology which demonstrates the state park's mission.

Figure 3. Stonewall Jackson Lake State Properties

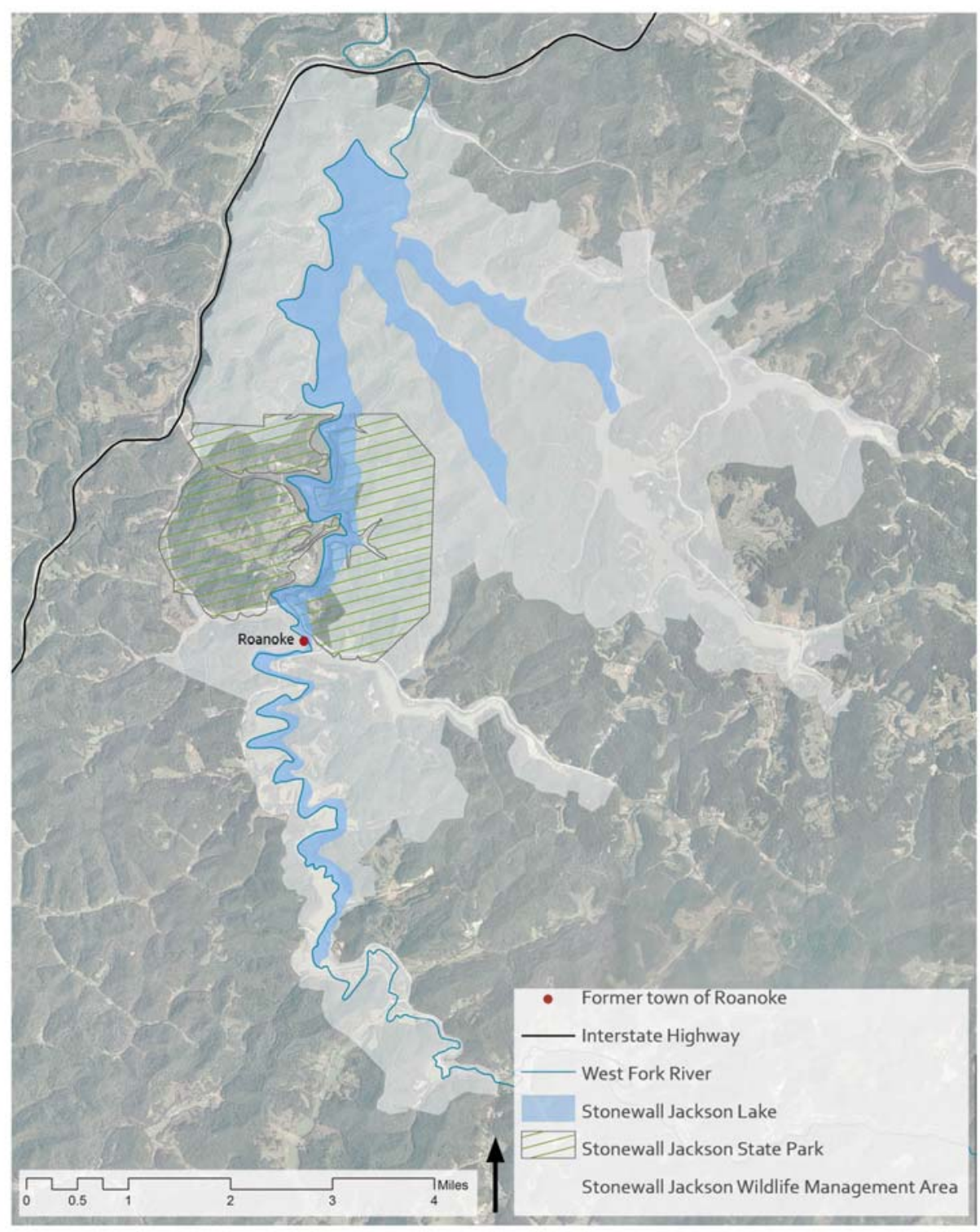




\section{CHAPTER 1: Defining the Problem}

Traditional methods of stormwater infrastructure collect water in storm pipes as quickly as possible and deposit the untreated water in a nearby water body. These methods often result in stream channel erosion, siltation, sedimentation, flooding, increased water temperatures, and habitat degradation which decrease water quality and infiltration (MDE, 2009). In an effort to reduce the impacts of traditional urban stormwater conventions, sustainable practices try to mimic ecological processes using soil and plant mediums to cleanse, cool and slow water in order to reduce and treat stormwater runoff before it reaches the stream. The United States Environmental Protection Agency explains that "unlike single-purpose gray stormwater infrastructure, which uses pipes to dispose of rainwater, green infrastructure uses vegetation and soil to manage rainwater where it falls”. Stonewall Jackson Resort was designed with the singlepurpose gray stormwater infrastructure. This form of stormwater management impacts the lake's water quality by depositing sediments and chemicals found on parking lots. With the implementation of Artful Rainwater Design, the project site will physically engage visitors with the ecological systems (Echols, 2008). The emphasis on stormwater management design can be marketed as a model for other state parks, making Stonewall Jackson Lake State Park the leader in this interactive display of ecological processes. Through my research I plan to find answers to the following questions:

1. What problems are occurring as a result of stormwater runoff?

2. What specific green infrastructure techniques can improve water quality and reduce runoff into the lake?

3. How can green infrastructure be used to connect people to nature?

4. How can green infrastructure be designed with Artful Rainwater Design to educate and enhance the entire experience of the public to the state park? 
5. How can a retrofit of the stormwater management be of value to the state park?

6. How can a model of best management practices be developed for other state parks?

\section{CHAPTER 2: Literature Review}

\section{STORMWATER TODAY}

The massive and drastic development of the land during the past century has transformed the natural landscape and its systems. The hydrologic cycle has been disrupted as a result of the construction of impervious surfaces, such as roads, buildings and parking lots (PBES, 2008). Impervious surfaces increase stormwater runoff, eroding soil carrying pollutants while also reducing groundwater infiltration. Pollutants such as nutrients, suspended solids, hydrocarbons, pesticides, and metals that accumulate on impervious surfaces are discharged through storm pipes into streams. Impervious surfaces also reduce the opportunity for water to infiltrate through soil and recharge to groundwater, which is a source for drinking water (MDE, 2009). In order for the hydrologic cycle to be repaired, new approaches have been developed and governments are implementing alternative design approaches that will be discussed in the following section.

It is important to note the landscape architect's role in the landscape ecological design process. At the brink of the profession of landscape architecture in America, Frederick Law Olmsted and Charles Eliot designed The Emerald Necklace in Boston during the late $19^{\text {th }}$ century. The series of public parks incorporated an urban water treatment wetland system deceiving visitors into thinking the system was a part of the natural landscape (Tunney, 2000). The park system exemplifies an innovative attention to water quality in landscape architecture. 
Following Olmsted's legacy came a period where landscape architects began designing without nature in mind until the 1960s and 70s. Ian McHarg's, Design with Nature, returned attention back to an environmentally sensitive approach to design for a brief period before it was lost again in the 1980s (Tunney, 2000). Today, the advances in sustainable development have influenced the design choices for stormwater management (Stahre, 2008). The landscape architecture profession is embracing collaboration among engineers and planners to develop a functional, economically viable, and environmentally conscious approach for future development.

\section{LOW IMPACT DEVELOPMENT}

Today’s approach to stormwater management encourages more sustainable practices using Low Impact Development (LID), which was developed by Prince George’s County, Maryland in the early 1990s (EPA, 2000). According to the United States Environmental Protection Agency, “LID is an approach to land development (or re-development) that works with nature to manage stormwater as close to its source as possible” (EPA, 2012). LID is implemented to mimic the hydrologic cycle and ecological function of a landscape. Green infrastructure systems are developed to implement LID with methods including green roofs, permeable paving, rainwater harvesting, bioretention, bioswales and constructed wetlands. Each element works together as a system that enhances the success of one another. These techniques for stormwater management are successful with proper site inventories including soil permeability, water table depth, vegetative cover, hydrology and topography. Successful green infrastructure practices will enhance environmental and economic benefits. LID practices often reduce costs for construction and long term maintenance. One example is, 
“[...] an alternative LID stormwater control design for a new 270 unit apartment complex in Aberdeen, NC will save the developer approximately $72 \%$ or $\$ 175,000$ of the stormwater construction costs. On this project, almost all of the subsurface collection systems associated with curb and gutter projects have been eliminated. Strategically located bioretention areas, compact weir outfalls, depressions, grass channels, wetland swales and specially designed stormwater basins are some of the LID techniques used" (EPA, 2000).

The reduction of stormwater runoff, soil erosion, improved habitat and the removal of pollutants from water are some of the environmental benefits of LID. Green roofs and permeable pavers are highly effective in retaining stormwater on site, opposed to impervious surfaces where runoff quickly enters storm sewer systems. Both permeable pavement and green roofs retain, cool, and treat runoff which improves water quality and habitat. Similar to permeable pavement, bioretention systems collect, infiltrate, slow stormwater runoff, and additionally treat water in vegetated areas. The "first flush" of runoff contains the highest amount of pollutants; therefore green infrastructure systems receive and absorbs the pollutants before they enter streams. Pollutant removal is achieved through "physical and biological treatment processes occurring in the plant and soil complex" (EPA, 2000). Since 2004, the University of New Hampshire Stormwater Center has monitored 23 stormwater systems designed with an LID approach for their abilities to treat water pollution and reduce volume runoff. The research concludes that LID systems are more effective in improving water quality and in some cases more cost effective than traditional stormwater constructions, although the maintenance of the systems is critical for maximum performance. Bioretention areas, specifically, must be maintained for proper performance; otherwise the system will increase the amount of pollutants reaching streams. Without proper maintenance, bioretention areas will degrade ecosystems. There have been numerous studies on the effectiveness of bioretention cells. One example analyzed sixty-three rain events. Permeable pavers and bioretention systems 
were evaluated with respect to implementation and system performances such as cost and maintenance, cold climate, water quality treatment and water quantity control. Studies concluded that porous asphalt significantly reduced snow accumulation in comparison to impervious asphalt, although with significant amounts of snowfall, proper removal and salt application is necessary for porous asphalt (Ballestero, 2012). This report provides people with balanced evidence, both positive and negative, regarding green infrastructure effectiveness that can be used for making informed construction decisions.

\section{SUSTAINABLE URBAN DRAINAGE}

Progressive initiatives to stormwater management are being implemented in various states and municipalities across the United States. Internationally a similar concept, Sustainable Urban Drainage (SUD), has been adopted by the United Kingdom and Malmö, Sweden. The system was introduced to Malmö in the late 1980s, and since then it has been implemented and has become a part of the regulation. SUD was developed around the urban drainage triangle, which includes three circles overlapping with the following characteristics: quantity, quality and amenity. Each of these three elements must be considered equally when evaluating new drainage plans in a SUD system. SUD systems aim to involve planners and engineers to develop systems by adding value to a variety of areas such as aesthetic value, biological value, recreational value, environmental value, and economic value (Stahre, 2008). Traditional drainage systems do not become a part of the exterior environment, but rather are hidden underground. SUD systems are incorporated into landscape designs to not only enhance water quality, but to also become an experiential landscape amenity. These ideals correlate with the 
state park’s mission statement by maintaining healthy ecosystems which become amenities for visitors. The SUD values create an additional foundation for sustainable design initiatives.

\section{ARTFUL RAINWATER DESIGN (ARD)}

People have recognized that stormwater management design is more than function, but can also create a place for education and enjoyment, an “artful rainwater design”, a term coined by Stuart Echols and Eliza Pennypacker (Echols, 2008). They developed amenity goals and objectives for stormwater design techniques that can increase the landscape's attractiveness and value. These goals, each with specific objectives, include: education, recreation, safety, public relation, and aesthetic richness. This list becomes the foundation for creating ARD through various stormwater best management practices. LID stormwater management techniques should be designed to educate the visitor in a visible and legible manner; signage can either discourage or encourage interaction based on placement, text size and amount, and color (Echols, 2008). Also, designers who display integrity in their stormwater designs will gain the appreciation of the visitor by highlighting sustainable techniques. Expressive and creative signage is an alternative used in many designs to provide an educational experience, while also displaying the designer's attention to the needs of the visitor. Herbert Dreiseitl states, "the awareness of the general public plays a critical role in shifting values to bring about changes in political and economic priorities” (Dreiseitl, 1999). This statement concludes that public education within design programming may influence the future steps of stormwater management.

Sustainability education can be enhanced through recreation and interaction with stormwater management systems by showing and guiding the citizen through a process. A successful example of this application is Waterworks Garden in Renton, Washington, a sequence 
of garden rooms which follow the path of a wastewater treatment plant (Echols, 2008). The curving recreational path develops a sense of mystery guiding visitors to explore and discover so it keeps the participant engaged (Kaplan 1998). While interaction with designed elements can be amusing, it is important that safety is addressed in the design. Water treatment features must be designed to properly control access and water quantity to avoid drowning hazards and contact with untreated water. This will be important because the project site is a family destination with many children.

The final goal of ARD is aesthetic richness which means "the design is composed to create an experience of beauty and pleasure focused on the stormwater” (Echols, 2008). Stormwater designs can create visual, auditory and tactile experiences, providing visitors with a multisensory experience. As Robert Woodward states, "Water is not just a vital element in our lives, it can also be experienced in a whole variety of ways. It creates different kinds of atmosphere and moods that appeal to our feelings” (Dreiseitl, 2005). Visual lines of patterns, sounds of trickling water and the chance to feel the water all heighten one's awareness of an ecological process. For example, “Cistern Steps” in Seattle, encourages water interaction as "small, shallow basins and weirs cascade down the hill in a playful rhythm; and water is rendered particularly touchable by wrapping pedestrian steps around the basins” (Echols, 2008). The goals of ARD provide environmental benefits, economic benefits, and encourage regulation revisions. Similar to LID and SUD, ARD has an opportunity to become a part of regulation and pave the way of design's future.

Stormwater management is a critical issue across the globe. Fortunately guidelines are becoming more common and municipalities are adopting methods such as LID and SUD. These programs have the potential to make drastic changes in the treatment of stormwater runoff, and it 
is through designs such as those guided by ARD which can educate individuals to promote acceptance and further implementation. As people become aware, then change can occur.

\section{CHAPTER 3: Design Process and Methodology}

In design, problems are identified and critically analyzed before developing a process to solve the problem. A thorough understanding of the site's physical and human interaction is critical for the success of a design. This project highlights "ecosystems so that people will recognize their beauty and maintain it appropriately” (Nassauer, 1995). Following the research phase of the project, a deeper analysis of the existing conditions and issues was completed to prepare for designing. The analysis incorporated photographs, drawings, diagrams, and maps to examine the site from various perspectives. The following sections (research, analysis and design synthesis) group the three phases of the design process. Each section is further explained in the following pages.

Research:

A. Site Context: The first step of the design process was to collect information on the history and meaning of place of the project site. Stonewall Jackson Lake and State Park was constructed by the Army Corps of Engineers when the West Fork River was dammed in the late 1980s. Therefore, an understanding of the former town, Roanoke, is included in the site context. This section also includes information on the history of the dammed lake, state park, and resort providing a foundation for the design project. The understanding of prior land uses and the significance of surrounding areas will become a part of the design influence. Literature, legal documents and oral history contribute to the 
findings for the site context. All gathered information was developed into a visual explanation with an accompanying text.

B. Program Information: The program of the project includes a retrofit of the current stormwater management system using ARD as a basis for the development of design. Green infrastructure systems such as bioretention, bioswales, and constructed wetlands will become interpretive educational experiences for visitors. An experiential trail and small gathering spaces around the lodge will become places for passive recreation and environmental interaction. A new nature play ground will become a children's destination for exploration and entertainment. An array of vegetative plant zones will enhance guest services and amenities to the lodge. A circulation plan will be designed to create experiential paths for visitors. The program was heavily defined by the park managers who conducted visitor surveys and interviews for proposed development ideas.

C. Site Inventory: Beginning in the spring of 2012, several site visits to Stonewall Jackson were completed. The following list exemplifies inventories completed prior to the final proposal:

- Completed a riparian forest tree survey

- Toured the site using multiple forms of transportation; walked, rode via car and golf cart, and boated to experience the site from all users’ perspectives

- Attended several meetings with the Stonewall Foundation (the stakeholder group spear-heading the new development projects in the park), the General Manager, Director of Resort Facilities, and DNR employees to learn about the history of the lake, state park, and private development 
- Organized a meeting with pre- and post-impoundment residents to gain cultural and social knowledge of the lake formation process

- Reviewed lodge guest surveys which were performed by the state park to learn of user’s program desires

- Captured many photographs of the site

- Performed a stormwater inventory of the peninsula site, collecting the Geographic Positioning System (GPS) coordinates of drainage inlets and outlets, while also noting important characteristics of the stormwater system

Following the proposal submission inventories expanded upon existing material by examining the physical, biological, cultural, social, sensory and phenomenological elements. The physical inventory includes an understanding of soils, topography, hydrology, climate, geology, and circulation. Wildlife and vegetation encompassed the biological inventory. Both the physical and biological inventories were compiled with Geographic Information System (GIS) data from various sources using ESRI ArcMap. The cultural inventory looks at items such as historic land use, legal issues regarding eminent domain, cultural significance and sensory information. GIS data is available for land use, although verbal and visual research was used for the majority of the cultural inventory. Observation was used to inventory circulation and sensory information, while the historic and legal issues were researched through literature and verbal communication. Maps and written text were completed to fully explain each inventory element. An additional and important inventory of stormwater expands on the hydrology inventory. For the purpose of the stormwater retrofit, a detailed understanding of the water paths and water quality is imperative. Visits to the site during different weather 
conditions developed a thorough understanding of the flow paths and issues occurring on site such as erosion, sedimentation and impervious surfaces. These analyses were used for determining green infrastructure systems and vegetation to address and mitigate particular issues. In addition to the technical inventory of the site, a sensory understanding, such as hearing, touching, smelling and feeling, developed a greater sense of how visitors would feel as they move through the site. Color, value, texture, pattern, density, and scale were examined to develop a characteristic palette of the site. Each inventory enhanced my understanding of how my design needs to respond to the user's engagement with the space.

Analysis

From the collected inventory information, analyses were combined to develop a further understanding of the character of the site. An analysis considers function, ecology, hydrology, sense of place, and the senses. These components were analyzed through developing a visual component with images and words to characterize the existing site systems. It was essential to keep environmental issues at hand when analyzing the site, as "Man is that uniquely conscious creature who can perceive and express. He must become the steward of biosphere. To do this he must design with nature” (McHarg, 1969). An environmental analysis combined the biological and physical inventories with attention given to the uses of the spaces. The environmental analysis took "many of those areas that can be improved ecologically in the process of benefitting people” (Kaplan, 1998). Issues specifically related to stormwater management, such as drainage patterns, sedimentation, erosion and vegetation, were analyzed in the environmental analysis. Following the analysis, stormwater calculations 
were made to determine the design size of green infrastructure. The Chesapeake Stormwater Network's method was used to estimate overland flow in urban hydrology for small watersheds (VADCR, 2011). This method takes into account rainfall, hydrologic soil groups, land cover and topography. Chesapeake Stormwater Network’s method calculates discharge (q) which can then be used to size green infrastructure elements such as bioretention, constructed wetlands, and bioswales. The cultural inventories were also analyzed, similar to the environmental analysis, with attention given to the user of the space. Visual aids help develop a greater understandings of the site. This analysis developed an understanding of the human interaction and influence on the site. Each specific analysis influenced the conceptual design.

\section{Design Synthesis}

With the analysis being the foundation for designing, each of these factors was addressed as a part of the design process. During this final phase of the design process, the project evolved and developed into a final design of stormwater management and amenity for the state park.

A. Site Conditions: Site conditions were identified from the analysis, indicating the suitability for specific program elements. Areas within the site have opportunities and limitations which impact what use is best for each space.

B. Relationship Diagrams: Relationship diagrams consider how different program elements interact with one another. These determine which program elements belong together or separate based on views, connections and sequence.

C. Functional Diagrams: Functional diagrams display how the space works; circulation, use, stormwater management and aesthetics were considered. 
D. Conceptual Design: The conceptual design takes all of the previous work and intentionally places the program elements into a spatial design, while developing an underlying design concept.

E. Stormwater Management Sizing: Chesapeake Stormwater Network and EPA design guidelines were used to size bioretention cells, bioswales and constructed wetlands throughout the project site. Once sized, specific location and designs were created.

F. Circulation and Grading: With the placement of the stormwater management elements completed, paths throughout the site were placed through numerous iterations of grading. A final grading plan for both circulation and stormwater management was then completed.

G. Planting Plan: The planting plan identifies plant zones for specific seed mixes based on site conditions. A signature plant palette was formed to create continuity and repetition throughout the entire site.

H. Master Plan: The master plan includes a final design solution for the stormwater management retrofit and individual spaces. Renderings for the master plan and each space were created to illustrate the final design. Cross sections display the topographic change and movement through each space.

I. Construction Documentation: Construction details were made for the green infrastructure designs, stone seating wall, bioswales stone cascades and wood deck.

J. Following the final presentation with the university, plan to will be presented to the stakeholders at Stonewall Jackson. This will provide an opportunity to articulate the design process and advocate for the benefits of the design, thus encouraging future implementation. 


\section{CHAPTER 4: Cultural Inventory and Analysis}

Roanoke, a late town in Lewis County, West Virginia, was settled by Europeans in the late $18^{\text {th }}$ century. Several men began purchasing large tracts of land, including John P. Duvall who purchased 400 acres in 1785 which included the site of Roanoke (Cook, 1924). Originally the property in the area around Roanoke was purchased for investment but not for settlement. The first known settler to live in the Roanoke area was John Mitchell who moved from Harrison County in the early $19^{\text {th }}$ century. The growth of Roanoke sparked with the construction of a grist mill which provided many jobs. In the early 1820s, M.G. Bush gained approval for the construction of a small dam in the West Fork River to build a grist mill on the water's edge. The hewn log structure named Bush’s Mill was located just north of Roanoke. The mill became a central node for the community when the post office opened at the mill in 1840. In addition to food production, the mill also chopped timber. With several years of production, the Bush Mill was damaged from severe floods and Civil War events resulting in the structure washing away in the river (Cook, 1924).

With the decline of the mill industry, locals turned to farming for alternative employment. Roanoke became a farming center for the region, particularly with the transportation opportunities of the railroad. The people raised cattle and turkeys for exporting, where the railroad station would handle thousands of head of cattle each year. The animals were shipped locally and to larger areas including Philadelphia and Baltimore. By the turn of the century, Lewis County ranked second in the state in cattle production (Carlisle, 1983). The railroad functioned as a passenger train as well; Roanoke residents traveled to Weston for recreation and social outings. In the mid $20^{\text {th }}$ century, the railroad tracks closed and Route 19 became the alternative mode of transportation. Some residents believe this change marked the 
end of the best days of Roanoke; people moved, stores closed, and Weston became the center for shopping and recreation (Carlisle, 1983). In the 1980s, the Stonewall Jackson Lake and Dam proposal threatened the town of Roanoke's existence. Nineteen-thousand five-hundred acres was taken by eminent domain for the state park and wildlife management area, including hundreds of private properties and residents. Residents were forced to leave Roanoke as the former town became the site of the dam reservoir. Today, very few remnants of Roanoke are visible to the visitor of Stonewall Jackson State Park; therefore, a part of this project includes understanding, as well as reflecting on significant cultural elements throughout the design.

An aerial image analysis displays similarities and differences between the 1939 and 2009 landscape of Roanoke. In 1939, property owners of the Roanoke area cleared land for farming and pastures (Fig. 4). The light color polygons on the map indicate forest-clearing practices. The small map shows a better image of the town of Roanoke and its proximity to the West Fork River. This current map shows that complete removal of Roanoke with the construction of the lake (Fig. 5). The small, yet confined riverside town sat on the lowlands which was submerged with the impoundment. The existing Route 19 was re-routed along the outskirt of the state park property. Underneath Carrion Bay, the remnants of Route 19 remain, as well as the forested trees. Dead tree tops sprinkle the edge of Carrion Bay giving sign to its previous life. The overlay shows that the project site was not originally along the West Fork River, although it is evident that Route 19 ran directly through the site (Fig. 6). This indicates that the land was graded and relatively flat for the road prior to the construction of the state park. Also the lake closely follows the original pattern of the river, as the lake was simply dammed and filled without landform destruction. 
Figure 4. 1939 Site Aerial Image

\section{Aerial Image 1939}

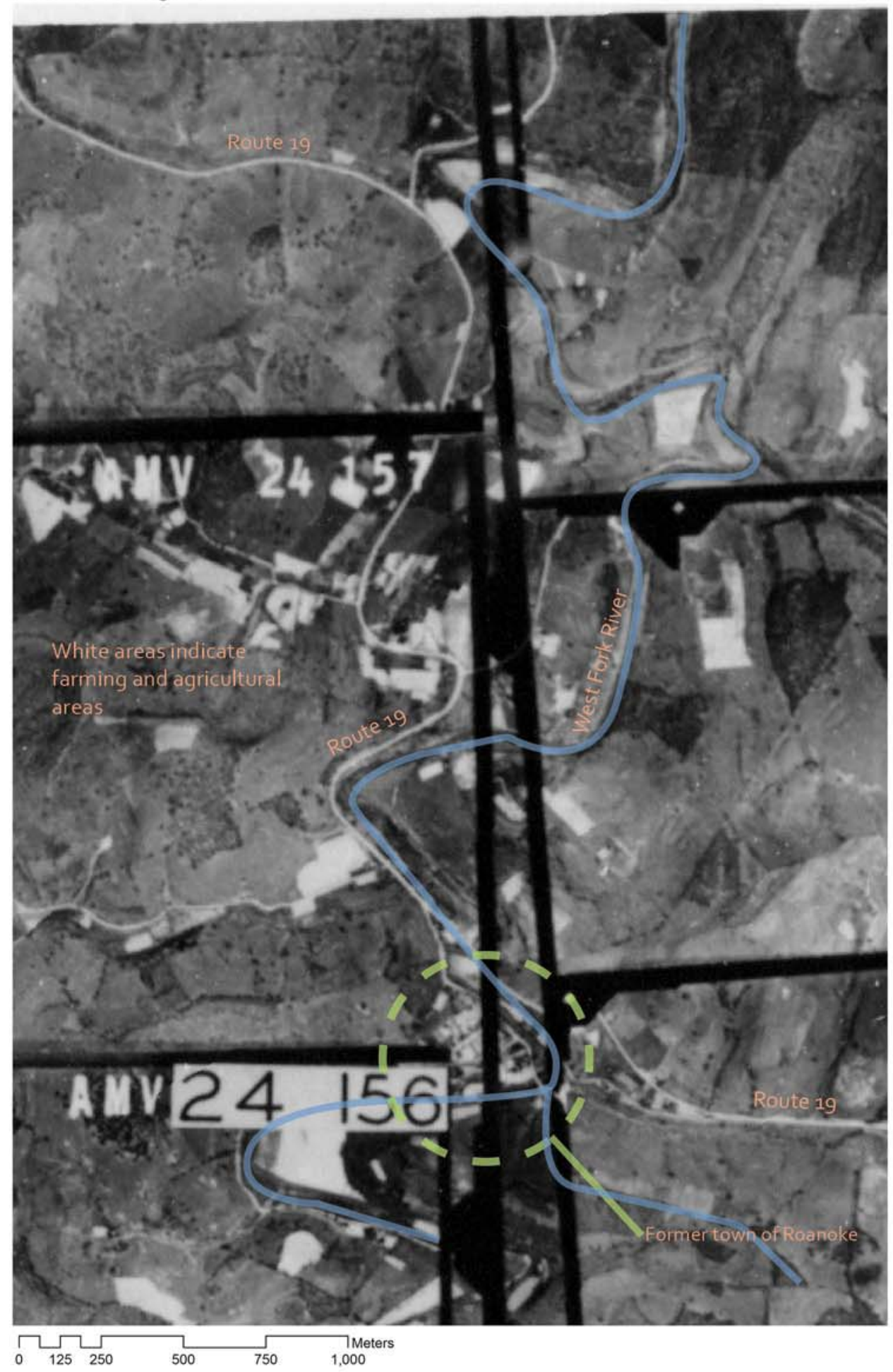


Figure. 5. 2009 Site Aerial Image

\section{Aerial Image 2009}

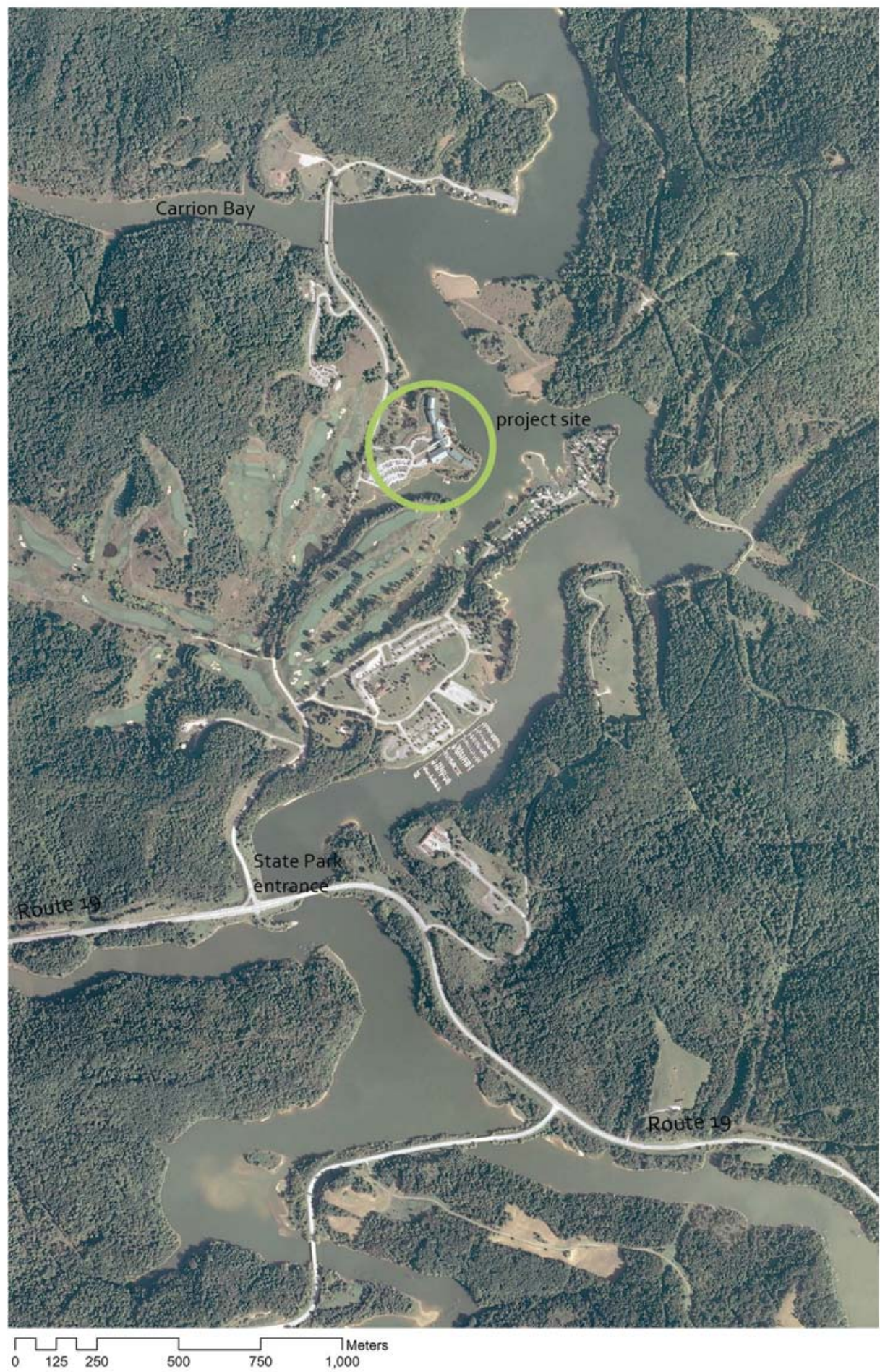


Figure. 6. 1939 and 2009 Image Overlay

\section{Aerial Image Overlay}

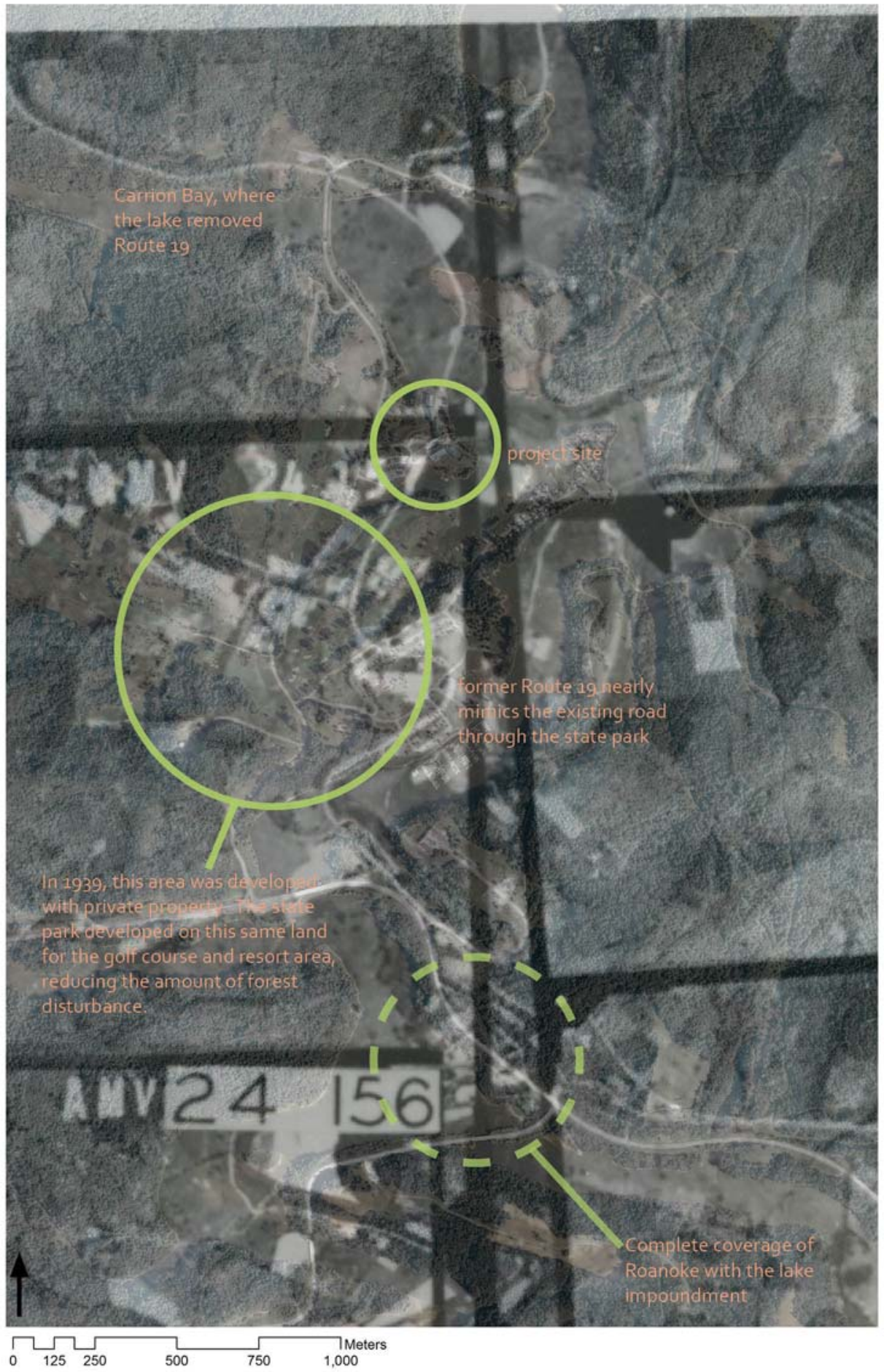


Beyond the growth and economics of Roanoke, an understanding of the people and their life in Roanoke will expand the cultural context explanation. The original pioneers of Roanoke constructed simple log homes, although in the $20^{\text {th }}$ century people resided in one-story clapboard sided bungalows. Typically the homes included gables and chimneys; most homes contained several fireplaces throughout the house. Furniture was most commonly made from solid oak, providing people with modest and sturdy pieces. These homes set the stage for a vibrant community with many social gatherings.

The people of Roanoke were primarily of English, Irish and German descent. Despite different religious backgrounds, acceptance and tolerance of diversity was high creating a very active community. Several organizations brought the community resources together including the Methodist Protestant church, the local school, the Odd Fellows and the Farm Women's Club. In addition to religious activities, the Methodist Protestant church hosted many social events. The local school shared space with the church for social interactions including box socials, cake walks, and "'literaries' which blended the intellectual content of the Chautauqua Society with the entertainment content of an amateur night” (Carlisle, 1983). In 1923 the Extension Service of West Virginia University organized the Farm Women's Club which held formal meetings and lessons on improving home efficiency. The Odd Fellows included fraternal bodies that held social functions while secretly helping the needy people in the community. The women's auxiliary to this group was the Rebekahs who worked towards the same goals.

These groups brought people in the community together, but the families formed the backbone of Roanoke. People of Roanoke were regarded as highly independent and very neighborly. Hardworking, reliable people lived in Roanoke, creating a sense of trust and respect. Technology bypassed the community keeping the pace of life slower throughout much of the $20^{\text {th }}$ 
century; it was not until after World War II that houses began having electricity and families owning automobiles. As mentioned before, animal husbandry was dominant in the area, but one family thrived in the apple business. The Hevener family owned a large apple orchard which remained in operation until 1977. The family developed its own apple, the West Virginia Red York, which was federally patented. Several other family practices were common in Roanoke, becoming culturally important production activities. Some productions included quilts, lye soap, homemade clothing, gardening, canning and butter making. Gardens were of particular importance to families, since they relied on production for winter survival. Most families grew tomatoes, corn, cabbage, beans, peas, and potatoes. Additionally, sorghum was grown to make molasses and some families grew tobacco. Many home grown crops were converted into homemade alcoholic beverages including potato jack, hard cider and white lightning. In addition to crops, most families raised their own animals for home consumption.

Each cultural tradition of Roanoke shaped the community and gave the small town its identity. For the purpose of this project, a strong cultural understanding of Roanoke is imperative for the design process. The town of Roanoke no longer exists, and from the view along Route 19, one would never know that a town once existed. The state park hosts a Roanoke Reunion each spring for the former residents to gather and celebrate the past. This project provides an opportunity for significant cultural traditions and memories to be recognized and remembered. Design is an opportunity to turn historic memories into an experiential component that can be interpreted and enjoyed by all users. While explaining the life and stories of Roanoke, several memories stood out. Economically, the mill and farming industry not only provided for the community members but taught individuals a strong work ethic and sense of pride. The mills, cattle, turkeys and apples become symbols of the workforce and local goods of 
the area which can all be used as representative elements of the community. Despite the long hours of work, the members of Roanoke made social gatherings an important part of their lives. These events brought people together for not only personal agendas, but for the greater good of the community. The structured work schedule was reflected in the professionally organized meetings of these groups. Also, from the discovered paper relics, people from Roanoke chose to be informed on current events and literature. This awareness signifies a sense of curiosity and interest in the world outside of rural Roanoke. As designs progress forward in the area of Stonewall Jackson State Park, the concepts must simultaneously shift towards more sustainable practices while resurfacing the historic characteristics of social gathering spaces and outdoor recreation activities.

\section{CHAPTER 5: Vegetation and Wildlife Inventory and Analysis}

The two-thousand acres of state park is predominantly forested with the South Central Interior Mesophytic Forest as classified by the USGS GAP Land Cover Analysis (Fig. 7). This predominantly deciduous forest is highly diverse and typically found in somewhat protected landscapes in the Allegheny Plateau and Cumberland Plateau. The Mixed Mesophytic Communities are consistent with the South Central Interior Mesophytic Forest type. Dominant species include: Acer saccharum (Sugar Maple), Fagus grandifolia (American Beech), Liriodendron tulipifera (Tulip Tree), Tilia americana (American Basswood), Quercus rubra (Red Oak), Magnolia acuminate (Cucumber Tree), and Juglans nigra (Black Walnut). Understory layers are often very rich with an abundance of spring ephemerals wildflowers (NatureServe, 2006). The developed area (red) of the resort is surrounded by the Mesophytic Forest (green). Pasture/hay (yellow) land indicates grassland clearings in the landscape. 
Figure 7. USGS GAP Land Cover Map

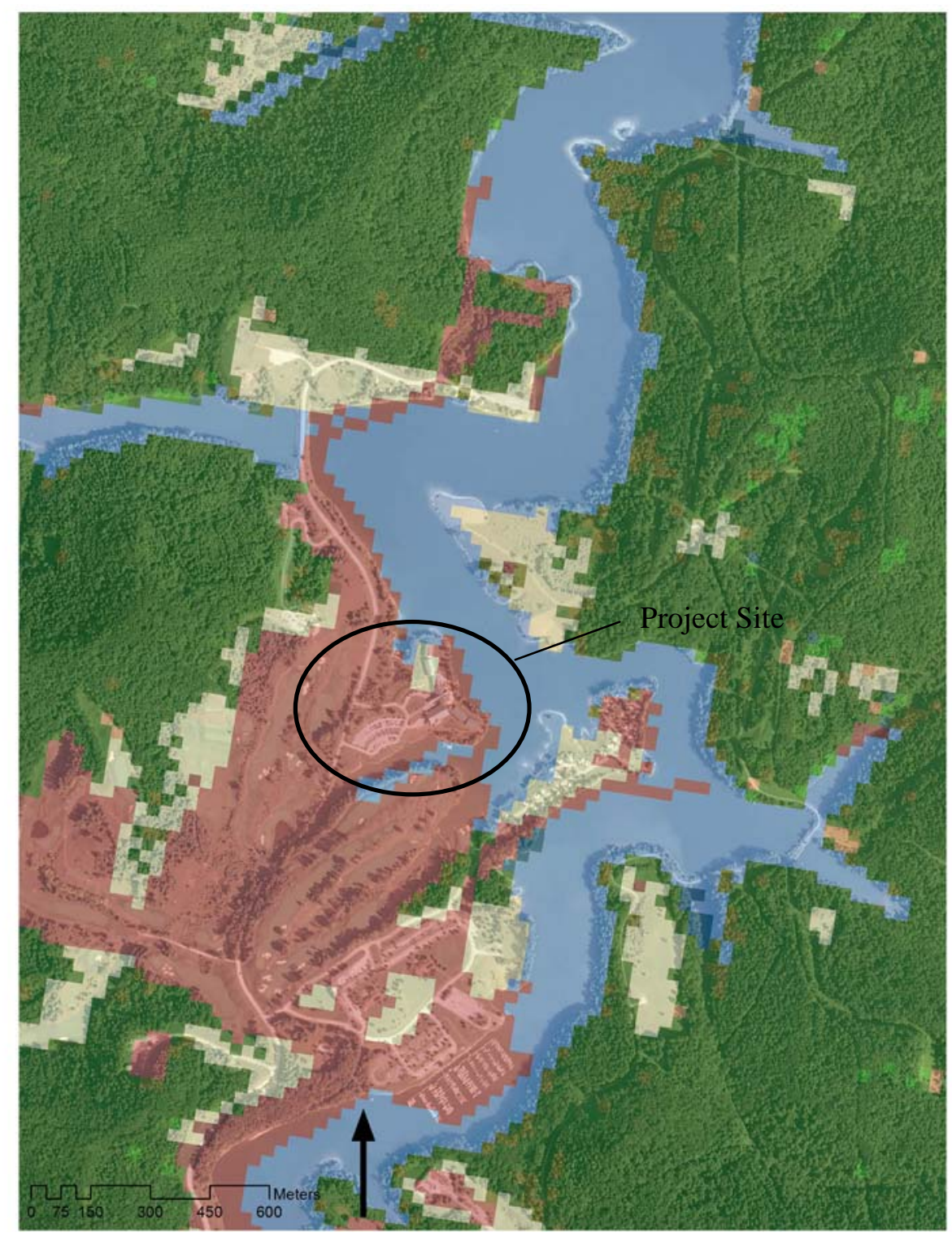

The vegetation on the lodge peninsula includes both native, naturalistic vegetation and pruned planted vegetation (Fig. 8). The native vegetation grows on the perimeter of the peninsula along the water's edge and in the undeveloped cove area. Both climax hardwoods and successional trees inhabit the shoreline creating a natural forest feeling. While the developed land does not lend itself to a forest condition, more native plants would improve landscape ecology by stabilizing soils, increasing habitat, enhancing aesthetics and reducing maintenance 
expenses. The climax hardwoods seen on site include: Acer rubrum (Red Maple), Carpinus caroliniana (American Hornbeam), Carya ovata (Shagbark Hickory), Cornus florida (Flowering Dogwood), Fagus grandifolia (American Beech), Fraxinus americana (White Ash), Liriodendron tulipifera (Tulip Tree), and Pinus nigra (Black Pine). The successional trees and more dominant species seen on the site include: Acer negundo (Boxelder), Platanus occidentalis (Sycamore), and Prunus serotina (Black Cherry). Some invasive species grow in the cove area taking away nutrients and space for successful native perennials. Typha latifolia (Cattail), Rosa multiflora (Multiflora Rose) and Elaeagnus umbellate (Autumn Olive) outgrow native vegetation, creating a need for mitigation. Proper techniques can be used to remove invasives to create a natural forest/meadow area which will promote wildlife habitat and an overall stronger landscape ecosystem.

Figure 8. Existing Vegetation Areas

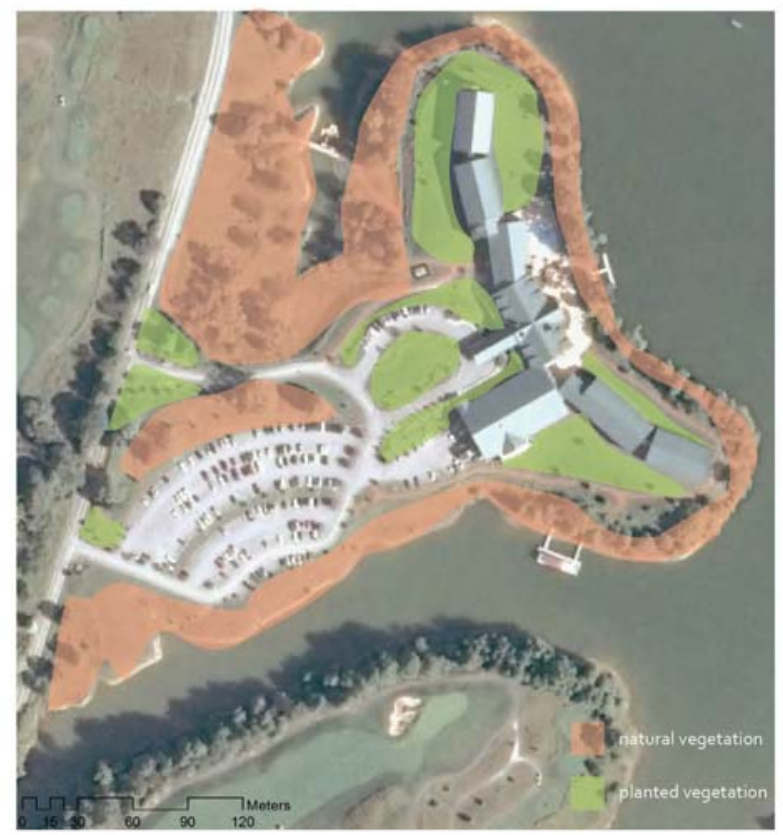


The planted vegetation around the lodge primarily consists of common non-native plants. Throughout the property, perennial shrubs (Juniperus sp., Potentilla sp., Cotoneaster sp., Picea glauca 'Conica', Berberis vulgaris, Buxus sp.), ornamental grasses (Liriope, sp), and ornamental trees (Betula papyrifera, Prunus cerasifera) sprinkle the landscape. Planting beds are mulched and ornamental shrubs are neatly pruned. The planting palette is limited to discourage deer browsing. These landscaping techniques are high-maintenance and of formal style, and do not appear to represent the spirit of state park designs. Native vegetation around the lodge would strengthen habitat by connecting landscape ecology with the surrounding aquatic and terrestrial ecosystems, while also reducing maintenance. Enhancing the landscape with greater vegetative cover will not only benefit ecology, but create a stronger sense of place for people visiting the lodge. Vegetation will be used to evoke feelings and create spaces which would enhance the visitors' experience and enjoyment at the park.

Within the forest and lake of Stonewall Jackson State Park, wildlife habitats are very diverse. Large to small mammals such as white-tail deer, chipmunks, rabbits, squirrels, groundhogs, raccoons and beavers walk the forests and water's edge. Frogs, turtles and salamanders live in and around the lake, while carp, catfish, trout, and bass are found in the lake creating a healthy habitat and environment for fishing. The West Virginia DNR stocks the West Fork River with Muskellunge. These habitats create a unique wildlife experience for visitors to see animals in their natural environment. This project's environmental enhancements will seek to create a biodiverse habitat bringing more wildlife onto the lodge peninsula. 


\section{CHAPTER 6: Physical Inventory and Analysis}

\section{STATE PARK AMENITIES}

Upon entering the state park from Route 19, a driveway leads visitors through a check-in. As part of the original park construction in the 1990s, the day-use activity areas, camping sites, and marina offer many opportunities to guests (Fig. 9). The marina offers boat slip rentals, pontoon and fishing boat rentals, aqua cycle rentals, and rides on the 100-passenger Little Sorrel touring boat. Guided Segway ${ }^{\circledR}$ tours are offered as a way to explore the park. The Roanoke Activity Plaza offers mini golf, a climbing wall, Frisbee golf and a variety of bikes for kids of all ages. The campground is available year-round with both RV and tent sites. A pedestrian bridge connecting the lodge to the camping and activity area opened in 2012. Some of Roanoke’s history has been preserved with a small cemetery on-site.

Figure 9. Stonewall Jackson Lake State Park Map

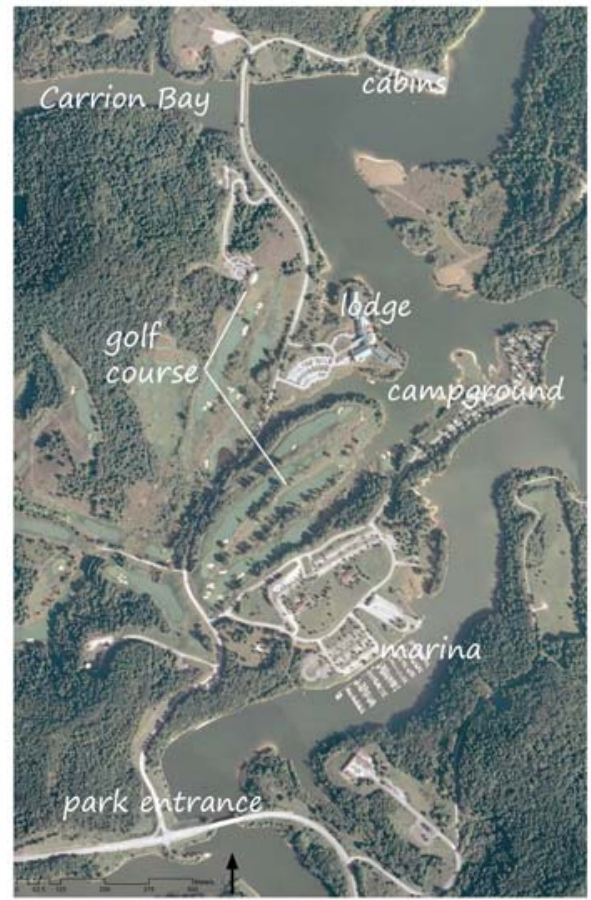


The new construction in the 2000s expanded the state park amenities with first, the golf course. This 7,149 yard golf course was designed by Arnold Palmer, attracting avid golfers from around the world. The 18-hole course weaves through the steep terrain providing players with a challenging and beautiful experience. The course achieved Audubon certification ensuring sustainable practices for construction and maintenance. The clubhouse overlooks the golf course with views of the lodge and surrounding landscape. The clubhouse restaurant, Lightburn's provides another dining amenity to the state park during the golf season.

Situated on a peninsula below the golf course, the lodge offers 198 rooms for guests of the state park. The building overlooks the lake from all angles. A conference center offers space for weddings, meetings and other special occasions. Two restaurants, Stillwaters and TJ Muskies, provide guests with dining options in the lodge. This peninsula is the specific site of this project and will be described in more depth.

Beyond the lodge and golf course entrance, visitors cross a bridge to access trail heads and the cottage area. Carrion Bay sits to the west and can be accessed by small boat through a large culvert. A proposed ADA trail around the bay is in progress. The resort offers lakeside cottage rentals for guests. Cottages range from 2-4 bedrooms, and each of them has washer and dryers, full kitchens, and outdoor decks with grills. Guests have a private boat launch and area for trailer parking.

\section{CIRCULATION AND SITE AMENITIES}

Upon entering the lodge peninsula, one travels through the large parking lot (Fig. 10). The parking lots are paved asphalt masses which increase stormwater runoff. The main parking lot offers two-hundred eighty-eight spaces. The service entrance provides twenty-two spaces 
while the entrance offers seventeen spaces. A few planting beds decorate the parking lot, although the raised mulch beds increase sedimentation rather than infiltrate stormwater. Concrete curbed sidewalks frame the entrance to the lodge, but end before the parking lot begins. Pedestrians must walk through the parking lot, because there is no designated path for people (Fig. 11). The walking path around the lodge begins at two locations near the parking lot, neither of which is connected to sidewalks. Both entrances connect to the road for automobile traffic. The walking path is delineated using a reddish orange crushed brick material. This aggregate is meant to be used in flat areas, where the material will settle. The path takes pedestrians up and down slopes, which results in stormwater runoff erosion of the path. As mentioned before, the aggregate material washes down the slope causing sedimentation in the lake and creating expenses for the park. In order to avoid the large expense of replacing the entire walking path, stormwater runoff must be diverted and retained to prevent the continual erosion. Overall the resort area needs to place more emphasis on pedestrian circulation rather than automobile circulation.

Figure 10. Existing Site Amenities

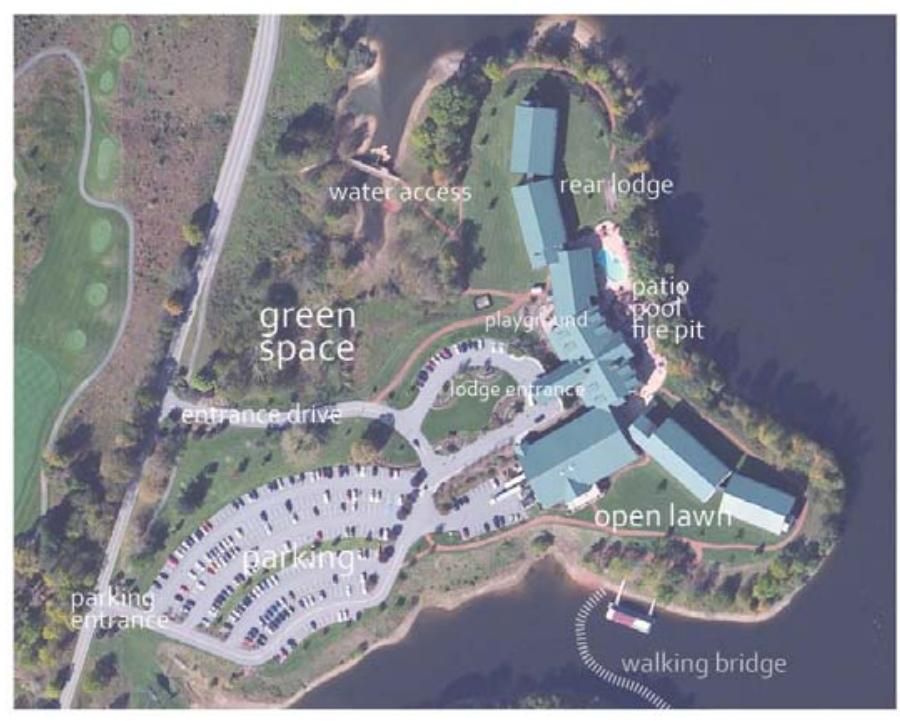


Figure 11. Existing Site Circulation

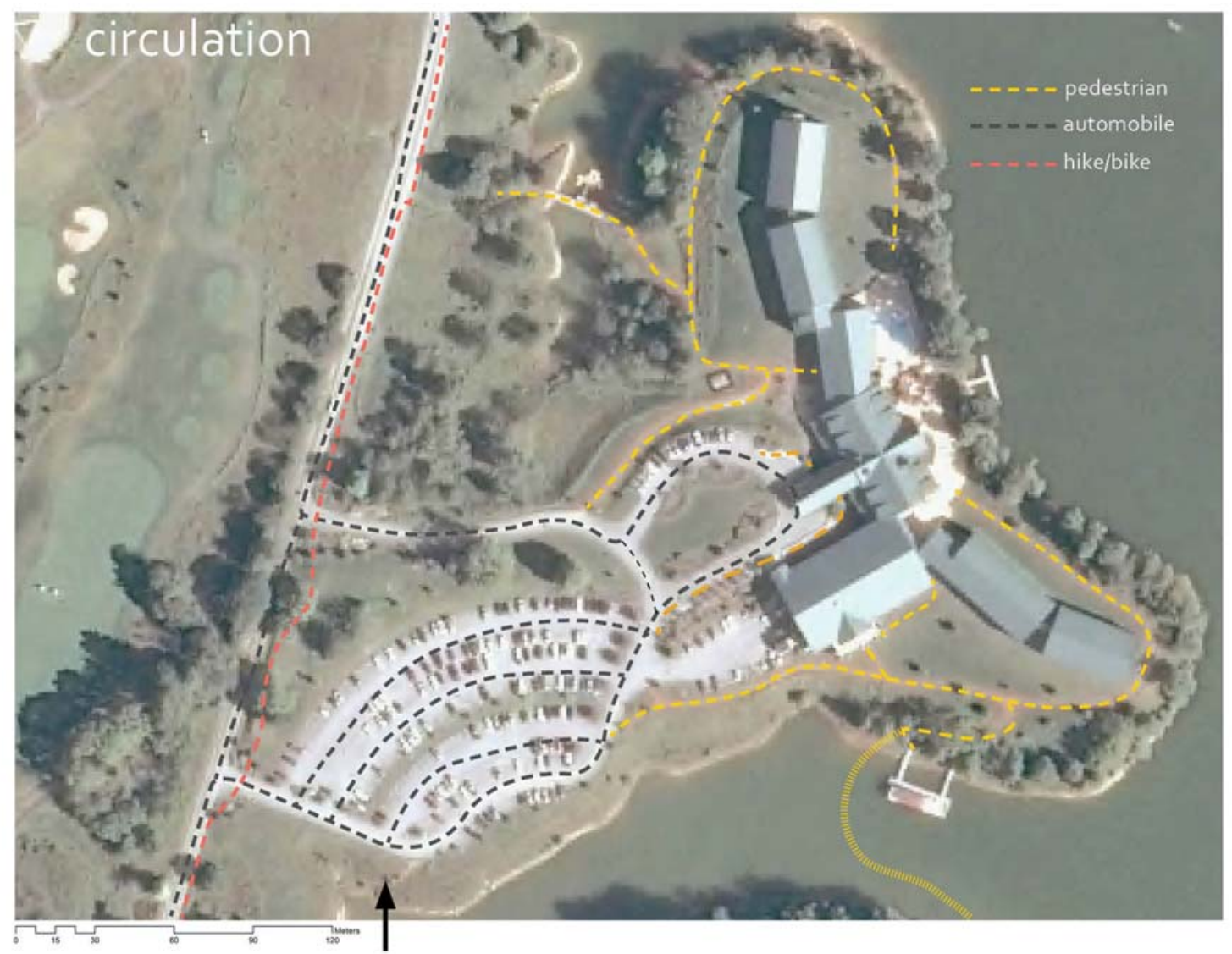

From the parking lot, the red path leads visitors around the south edge of the peninsula where one approaches an open lawn. This green space is connected to the conference center of the lodge, where an open patio is often used for gatherings and events. The lawn provides a large open space for weddings, reunions and other celebrations for large groups. Connected to this space is a path leading to the newly constructed pedestrian bridge which links the lodge to the camp site. Next to the walking bridge is the Little Sorrel tour boat dock which takes visitors and guests of the lodge on dinner and event rides throughout the lake.

The crushed brick path leads one around the lodge to the east edge of the peninsula where a large patio opens from the lodge restaurant and lobby. An indoor/outdoor swimming pool is 
surrounded by a large fenced in deck. During the summer month, patrons of the adjacent restaurant can choose to sit outside. A fire pit on the patio becomes a gathering space for guests while overlooking the lake. From the pool side of the patio, a disconnected path creates confusion and barriers for people. An opening in the pool fence is not connected to the existing crushed brick path, but instead opens to an open green lawn with horseshoe pits and a volleyball net. The path follows the north edge and approaches the lodge's playground.

The playground area, adjacent to the lodge, comes across as an afterthought. The fenced in area is squeezed in a corner between two buildings. The mulched area offers children with generic plastic play equipment. The lodge has the opportunity to create a natural adventure playground for kids to explore, create and exercise. Several other areas on the site lend themselves to a more functional and enriching location for a play area.

A path leading from the playground connects to an open vegetated area. Guests can walk from the lodge to a small wooden bridge where paddle boats and kayaks are launched. The green space is sprinkled with hardwoods and successional trees as mentioned in the vegetation analysis. The green space is characterized by the rolling topography which creates a number of intimate areas. The majority of the space is unused, but one area covered with trees is furnished with log stools and picnic tables for guests. Summer camps for children of guests of the lodge gather in this space for outdoor exploration activities.

\section{MATERIALS}

Beginning with the lodge materials, the stone detail and wood beams are fitting to the setting and state park environment (Fig. 12). Although the beige siding and teal metal roof lose the integrity of the natural setting. The colors reflect the surroundings, but become vast strips of 
dull walls with generic fenestration. This bland backdrop could be enhanced with more vegetation near the buildings. Many areas around the building lack any vegetation which draws more attention to the building materials. It will be important to avoid obstructing views of the lake, therefore low-growing plants will be best suited for the area. Color, texture and shape could be provided with designed planting areas.

Figure 12. Existing Site Materials
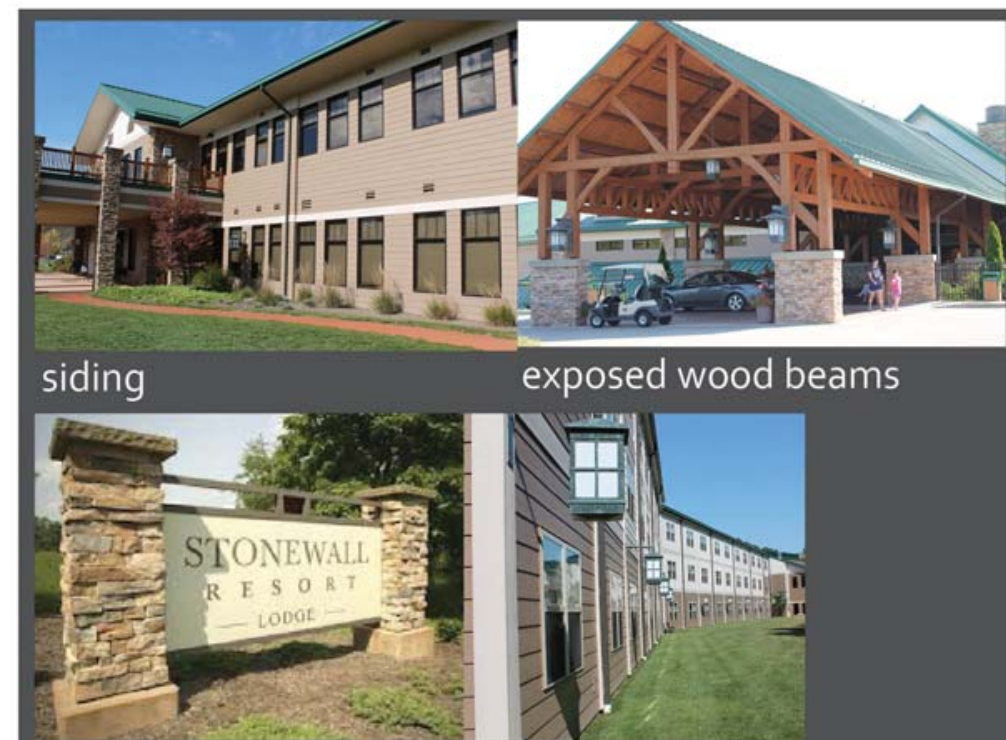

exposed wood beams

stone columns
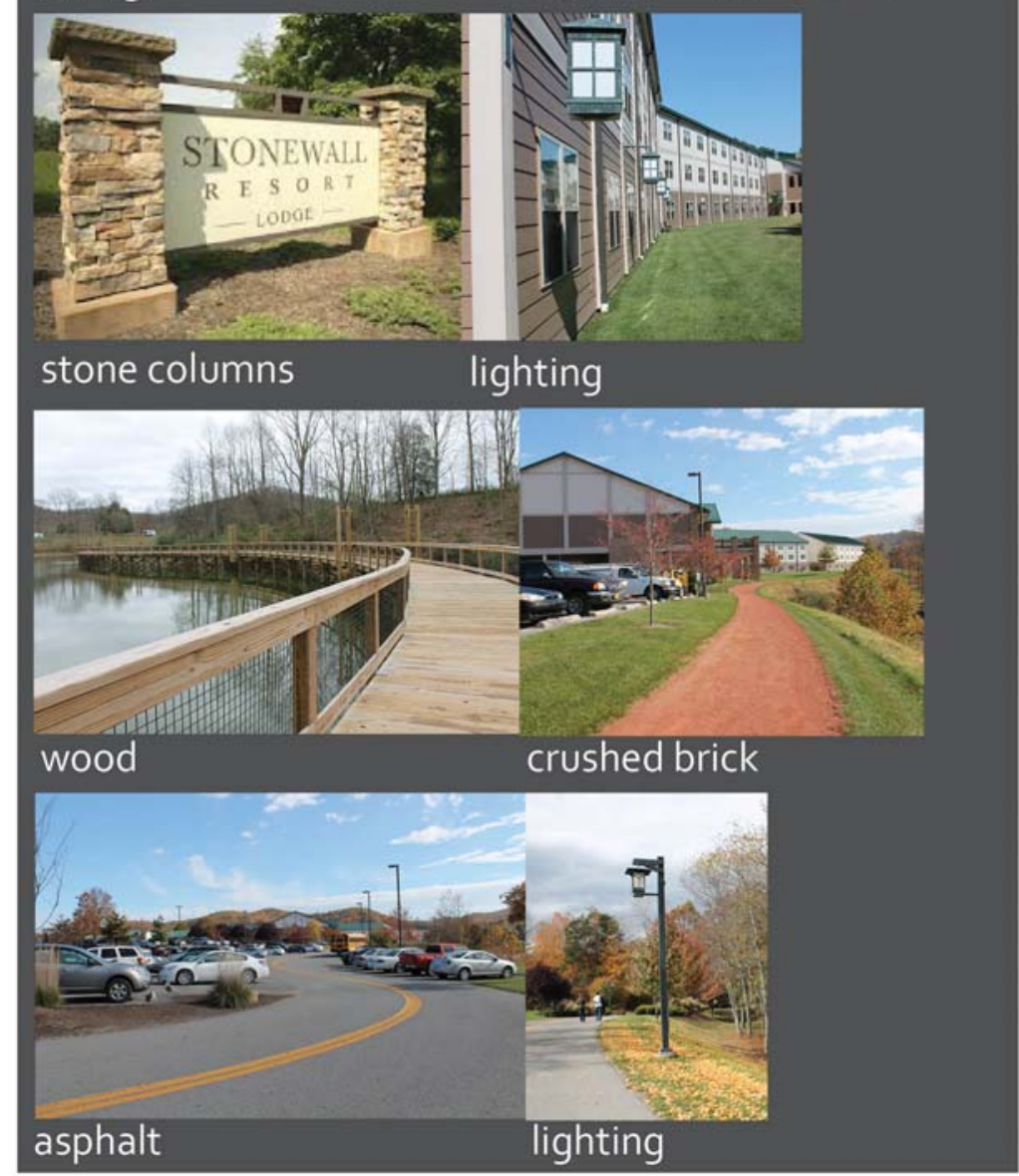
The lighting materials used around the lodge are limited to the parking lot, road and building (Fig. 12). Tall street lamps inefficiently light the parking. The lamp posts are out-ofscale to the car and pedestrian; lower lighting would create a more comfortable environment for people walking through the parking lot in the dark. The lighting fixtures around the lodge resembles lanterns. Both street lights and lights attached to the lodge are also very large. The street lamps are lower than the parking lot lamps, but could still be closer to pedestrian scale. The lamps attached to the building are over-sized and bulky. No lights illuminate the crushed brick path around the lodge. Proper lighting would create a safe and enjoyable atmosphere for summer evening strolls.

Signage along the street marks the entrance to the lodge peninsula (Fig. 12). Stone columns frame the sign which is accented with metal and glass detail. More signage would be beneficial around the lodge, such as in the parking lot to guide guests to the lodge. Signs near the walking path would help guests navigate and provide information about the trail. Signage telling visitors about the new walking bridge would be very useful as well, too.

\section{CHAPTER 7: Soil Inventory and Analysis}

The inventory described and located specific series and types of soils on the project site (Fig. 13). Gilpin-Upshur, Monongahela, and Vandalia are all silt loam soils and vary in slope steepness. Silt loam is a soil combination of silt and sand which vary in texture characteristics. Silt consists of medium-sized particles that allow both water penetration and water storage capacity. Sand is characterized by large particles that create large open spaces for water to move between quickly. Silt loam combines both of these characteristics, creating soils that can retain water while also having good permeability. 
Figure 13. Site Soil Type Map

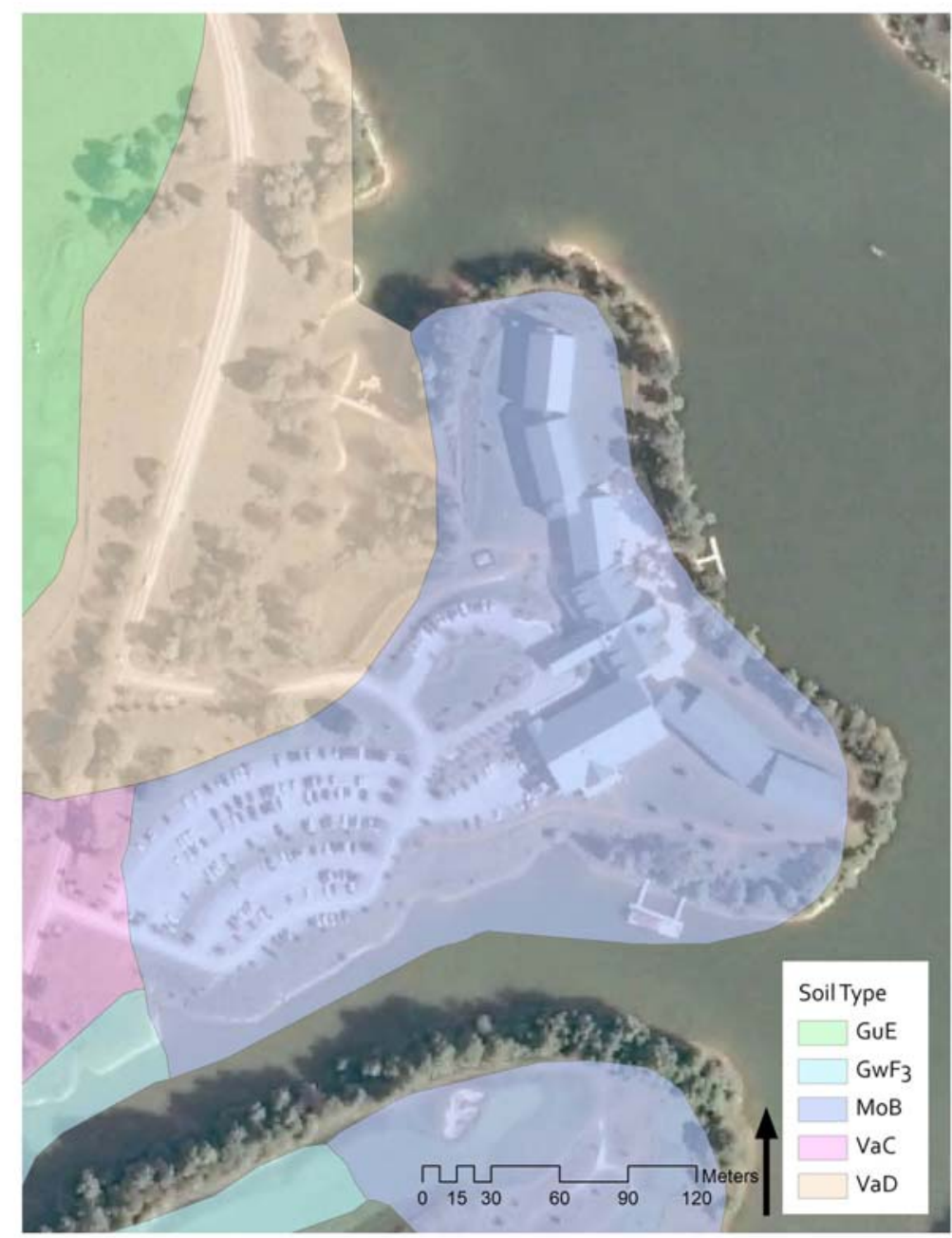

\begin{tabular}{l|l} 
GuE & Gilpin-Upshur silt loams, $25-35 \%$ slope \\
GwF3 & Gilpin-Upshur silt loams, 35-70\% slopes, severely eroded \\
MoB & Monongahela silt loams, 3-8\% slopes \\
VaC & Vandalia silt loams, $8-15 \%$ slopes \\
VaD & Vandalia silt loams, $15-25 \%$ slopes
\end{tabular}

The USGS Web Soil Survey described the MoB (Monongahela silt loam) to be well suited for hand planting of native forest plants, while the $\mathrm{VaD}$ (Vandalia silt loam) is moderately suited because of its stickiness and high plasticity index. For landscaped lawns, the current vegetation on the site, the MoB is somewhat limited because of its saturation level of 0.03 , and $\mathrm{VaD}$ is very limited because of the steep slopes. This report implies that the soils on the site are 
better suited for natural native vegetation than highly pruned and maintained green lawns.

Native vegetation will stabilize soils, prevent erosion and increase nutrient levels for a healthy ecosystem.

\section{CHAPTER 8: Hydrology Inventory and Analysis}

The topography of the peninsula varies, creating a challenging location for development. The slope on the peninsula is relatively flat where the parking lot and buildings have been developed, although the perimeter of the land is very steep, making access to the water difficult (Fig. 14). The impoundment of the lake forced waters to rise higher in the landscape; therefore the flat valleys are now underwater. In order to begin my stormwater hydrology analysis of the site, an inventory was conducted of the engineered stormwater system by GPS-locating the inlets and outlets. Pipe diameter, flow direction, and sedimentation were documented at each location (Fig. 15).

Figure 14. Site Slope Map

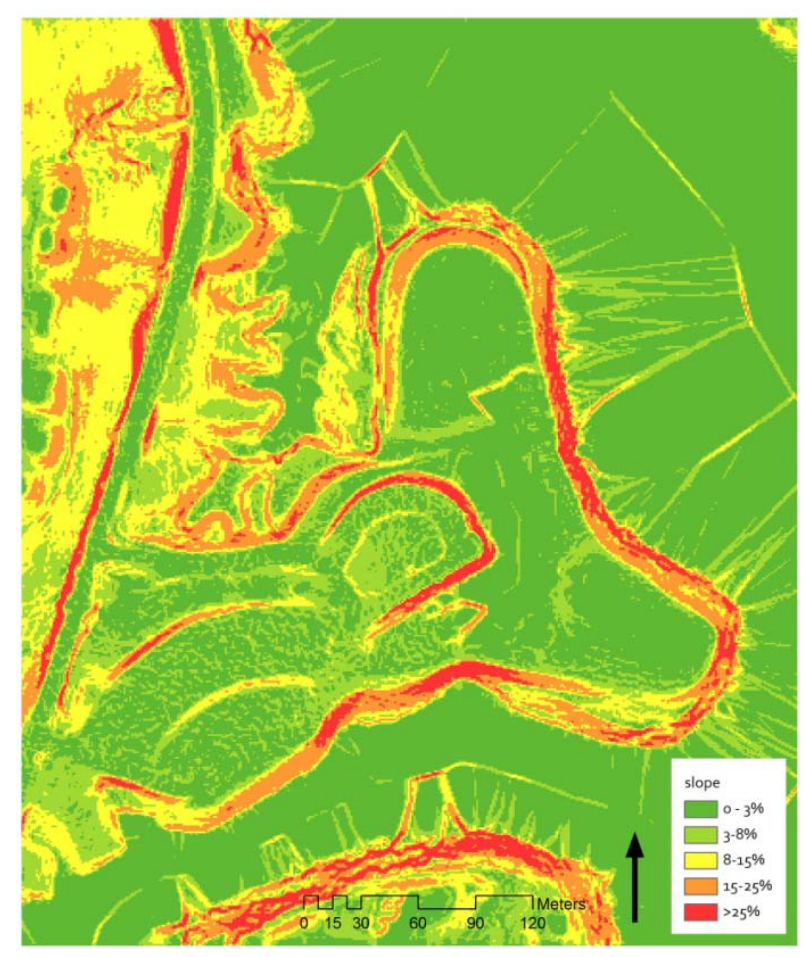


Figure 15. Drainage Inventory Map

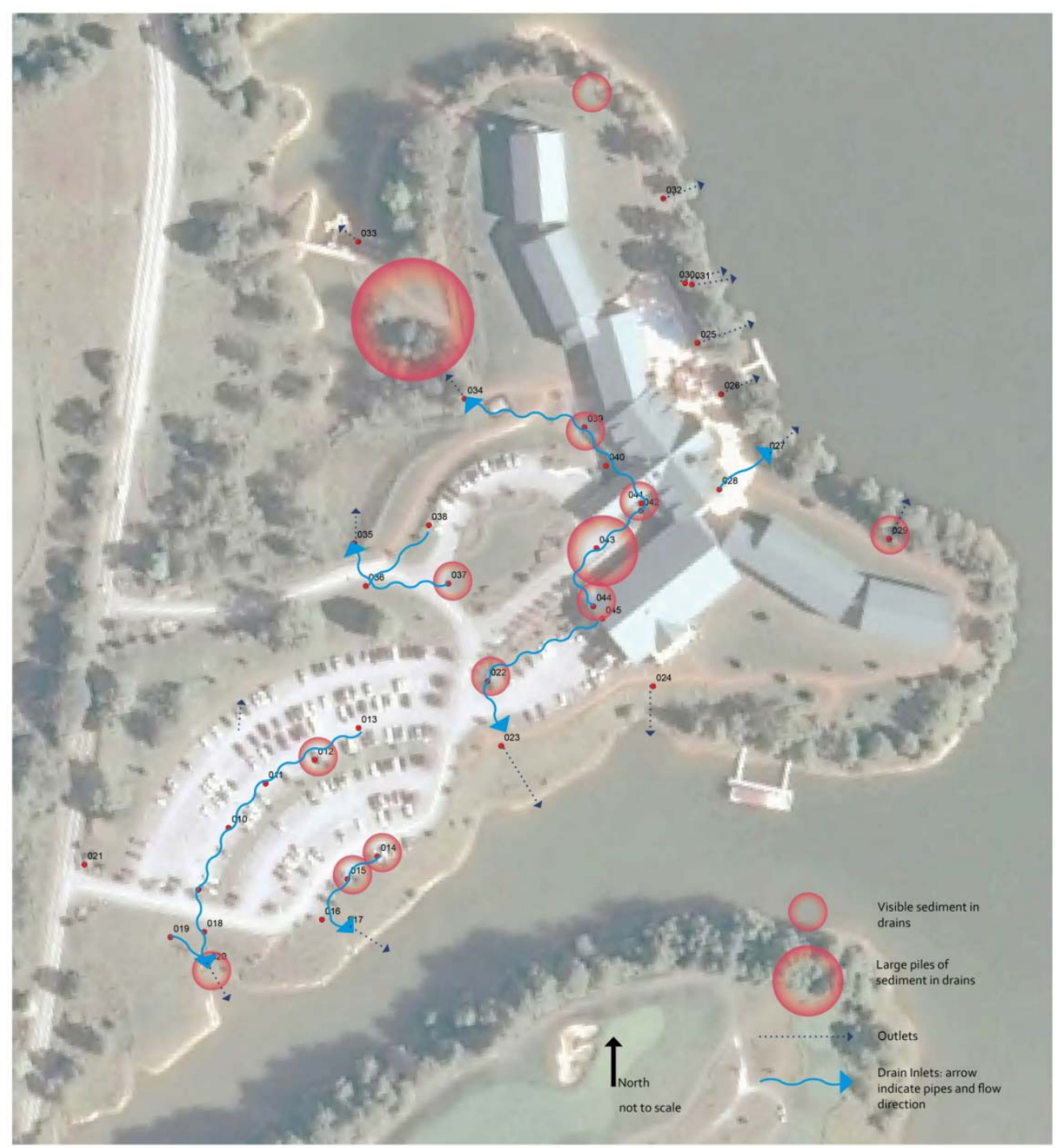

In addition to the GPS coordinates of the drains and pipes, I also photographed and inventoried areas of concern caused by stormwater runoff (Fig. 16). The crushed red brick path is being washed downhill into the lake starting from the playground path. The existing drainage pattern of the stormwater is not entering the storm pipes. Instead, the drainage is flowing overland and collecting and carrying the path material. A similar problem, though not as severe is happening on the north edge of the perimeter path. The steep slope and minimal vegetation induces runoff causing a sedimentation and erosion problem. 
Figure 16. Hydrology Analysis Map

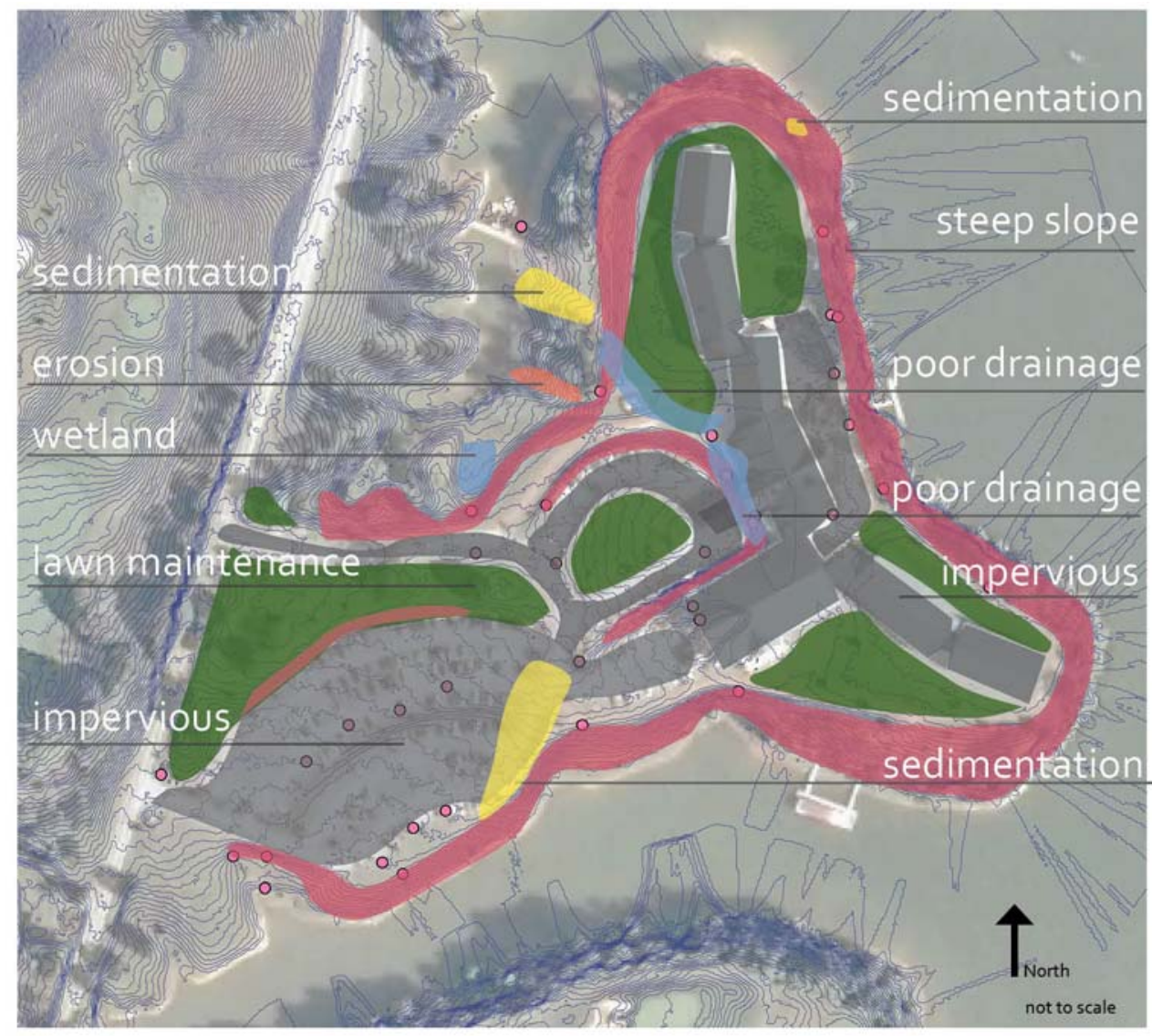

The impervious surfaces on site increase stormwater runoff, where the paved areas direct water towards drain inlets and pipe it to outlets near the perimeter of the lake (Fig. 16). Water collects sedimentation including mulch from the planting beds in the parking lot, vegetation debris, and small rocks. Any pollutants found on the parking lot and driveways are flushed into the drain that enters the lake. Snow melt applications consist of Potassium Chloride, Sodium Chloride, Magnesium Chloride, and Calcium Chloride which flow into the drains and lake during the winter months. Many opportunities exist for bioretention cells in the parking lots which would collect sediment and infiltrate water rather than piping it directly into the lake.

Other drainage elements noted on site included the gutter and pipe system and an orange/red colored stream flowing in the undeveloped vegetated area. The roofs collect 
stormwater in gutters and the pipes then run down the side of the building going underground to an outlet on the perimeter of the peninsula. This system eliminates any chance for rainwater to infiltrate and regenerate the groundwater, and instead flushes water as quickly as possible off site and out of sight. Any pollutants and sediments collected from the rooftops are directly piped into the lake. Rooftop pipes could be disconnected and conveyed into bioretention cells to permit infiltration and enhance vegetation. The other concerning issue observed during the inventory was a small stream flowing from a culvert in the cove area. With initial concerns of acid mine drainage, a background check of historic mines was completed to find that no mines were in the area. A state park official explained this incident has been seen in other areas around the state park property, and the West Virginia Division Environmental Protection was notified. The environmental test indicated an algae growth was causing the discoloration. This area is continually wet during the year and functions with wetland characteristics. Cattails and other water tolerant species fill the area. In addition to the red stream, water entering this area is collected from the vegetated and paved entrance to the lodge. The conveyed water collects sediment and automobile-derived pollutants. This area has the potential to be turned into a high functioning constructed wetland that promotes a diverse habitat, improves water quality, and becomes an interactive experience for visitors.

\section{CHAPTER 9: Composite Analysis}

The composite analysis combines each individual analysis to develop a greater understanding of site issues. View-sheds from the lodge to the lake must be preserved, hydrologic issues must be addressed with stormwater management, circulation holes need to be filled to create a cohesive path system, and existing landscaping must be reevaluated for function 
and sustainability (Fig. 17). Overall conclusions from the analysis can be divided into three categories for design consideration: assets, culture and enhancements. Assets to the site include views, the lake, natural cove area, open space, natural setting and the interstate access. Cultural reminders for design considerations are gardens, literature, social gatherings, apple orchards, cattle, turkeys, organization and discipline. Enhancements are needed to address the following issues: pedestrian circulation, scale-appropriate lighting, native vegetation, signage, the playground and stormwater runoff. Each of these ideas and suggestions are applied to the development of the conceptual design.

Figure 17. Composite Analysis Map

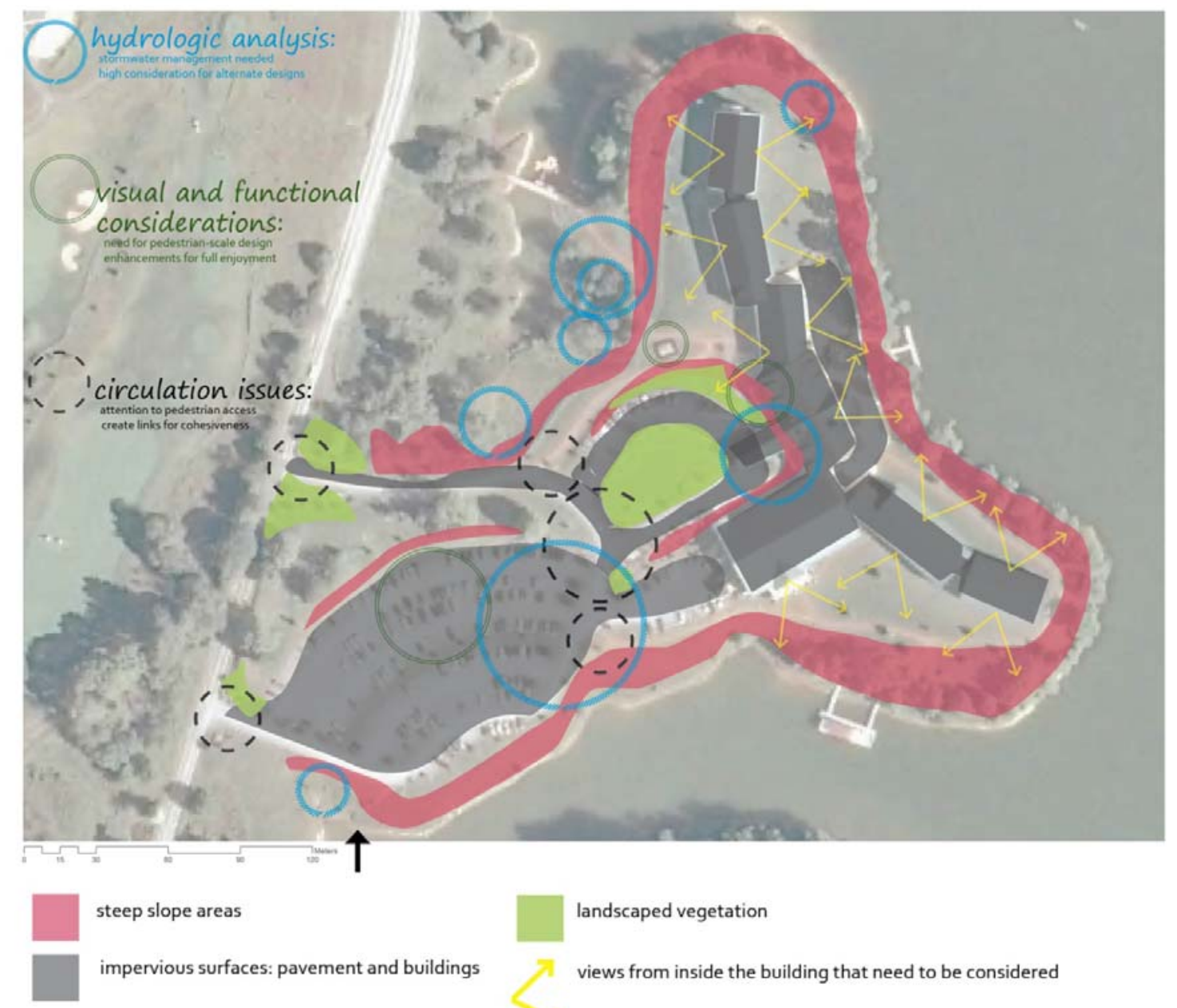




\section{CHAPTER 10: Program Development}

In order to develop the program of the site, state park desires, circulation, stormwater management and additional program opportunities were combined to develop a functional and appropriate program. The Stonewall State Park Foundation created development plans for the cove area, Bright Star Park. The plans are preliminary with a rough layout and program identified. This map illustrates the desired areas for an arboretum, butterfly garden and sensory garden (Fig. 18). The Foundation developed individual program elements for each space. An arboretum is a collection of trees and woody plants. The arboretum program included educational opportunities, an exhibit of native West Virginia trees, a picnic shelter and outdoor classrooms. A sensory garden is an accessible and enjoyable garden that provides individual and combined sensory opportunities. The desired program for the sensory garden includes a walking path, native West Virginia fragrant plants, an educational demonstration area, wine tasting area, a culinary demonstration area, and space for intimate weddings. Third, a butterfly garden is a wildlife garden that creates environments which attract butterflies and specific species of moths. Walking paths, native West Virginia flora, seating areas and a gate encompass the program for the butterfly garden. Each of these programs serves as the foundation for the site design. 
Figure 18. Stakeholder’s Program Map

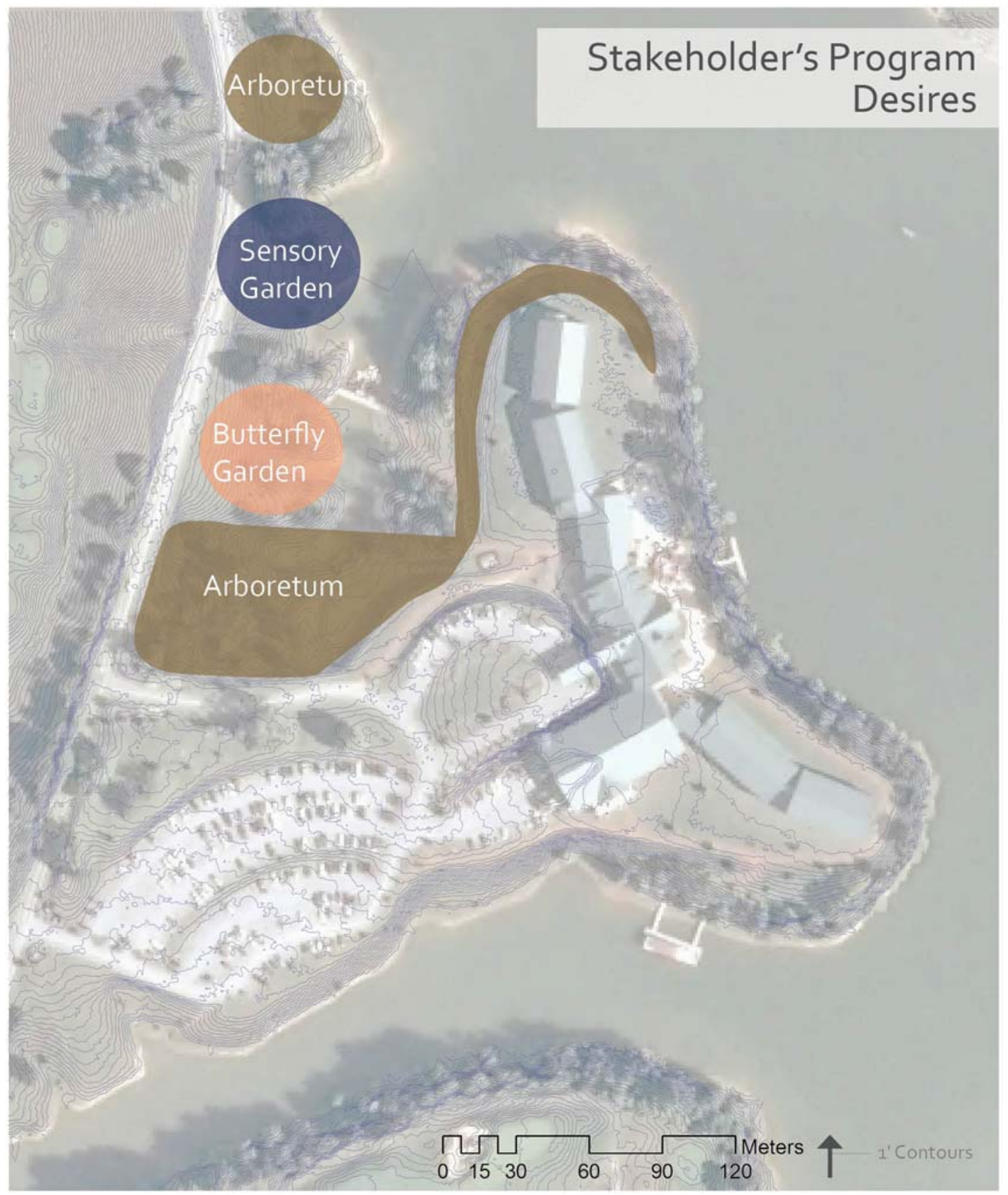

The next layer to the program development is the pedestrian circulation patterns. The circulation problems have been identified, but here a map illustrates the various types of paths and the existing disconnect between them (Fig. 19). The crushed brick path starts and stops several times, leading pedestrians to the parking lot and driveway. The sidewalk from the lodge 
entrance similarly ends in automobile traffic. No pedestrian path leads people from the road to the lodge, rather they are left to walk on the driveway or through the parking lot. The colorcoded paths on the map help identify where links and consistency are needed.

Figure 19. Pedestrian Circulation Map

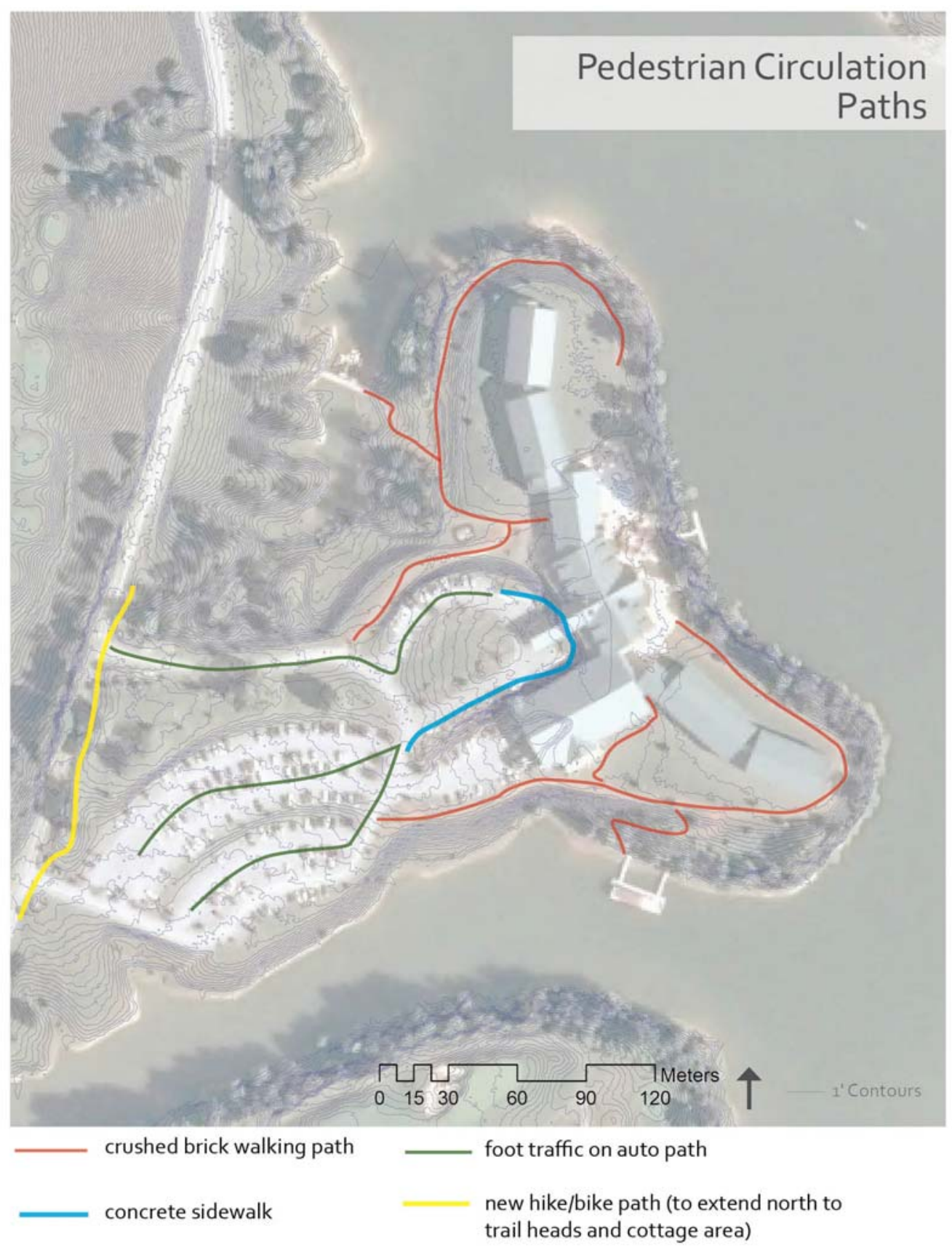


Through the inventory and analysis process, several other program elements were identified to enhance the experience around the lodge (Fig. 20). The existing playground is contained and hidden. As the resort is a family destination, a natural adventure play area would be a beneficial addition to the area. Children can explore nature and use their imagination. A designated entryway for pedestrians will invite guests into the property. An exciting vegetated allee can guide people to the lodge entrance away from the automobile traffic. The green space separating the parking lot and the main driveway is underutilized. The mature trees in this area create an inviting canopy for gathering space. A small seating area could become a meeting point for visitors planning to take a walk, hike or ride on the Little Sorrel. The event lawn on the south side of the property must maintain its open character, although foundation vegetation and creating an overhead canopy with native trees would enhance the experience. Vegetation will soften the hardscape of the building while creating picturesque backgrounds for event photographs. As discovered in the analysis section, pedestrian circulation is both absent in many places and lacking in functionality. An overall circulation re-design will connect each space of the peninsula and bring the focus to the pedestrian, not the automobile. Key changes will include moving people to and from the parking lot safely and enjoyably, closing gaps within the footpath and creating an enhanced experience when entering the lodge. 
Figure 20. Additional Program Map

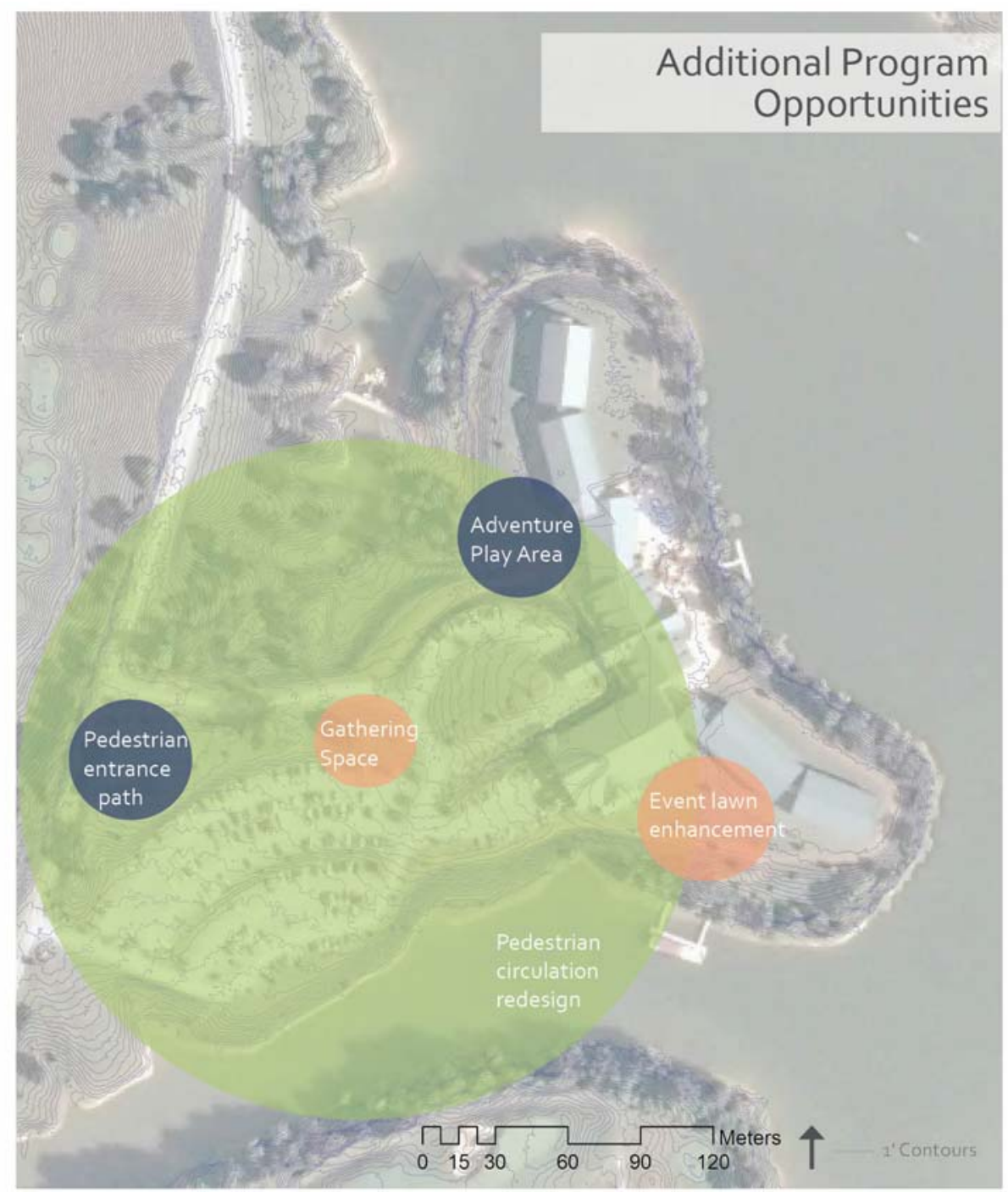

A major element for conceptual design is stormwater management. The analysis located specific areas which need stormwater management to not only help the drainage and landscape ecology, but to also become visual and experiential amenities to the site (Echols, 2008) (Fig. 21). Sweeping foundation plantings will become biorentention cells for the rooftop runoff. The parking lot will be enhanced with bioretention cells to collect stormwater runoff, reduce the sedimentation problem, and aesthetically improve the mass of asphalt. The erosion problem beginning from the path near the playground all the way to the lake can be developed into a 
design element. The path can run alongside a bioswale for a visual and physical experience. Auditory experiences will be enhanced during rain events. The existing wetland can be designed into a high functioning constructed wetland that promotes natural habitat while treating stormwater runoff. The elevated walkway entrance into the lodge overlooks a vegetated and mulched area between the steep slope and building foundation. This area is poorly drained and pools water in rain events. A designed bioretention cell will collect and infiltrated stormwater and be seen from the aerial view. Both soft and hardscapes could be used to create a functional and visual amenity for the entrance of the lodge. Each of the stormwater management methods will be developed into educational components that allow visitors to see and experience the sustainable alternatives opposed to conventional methods.

Figure 21. Stormwater Management Possibilities Map

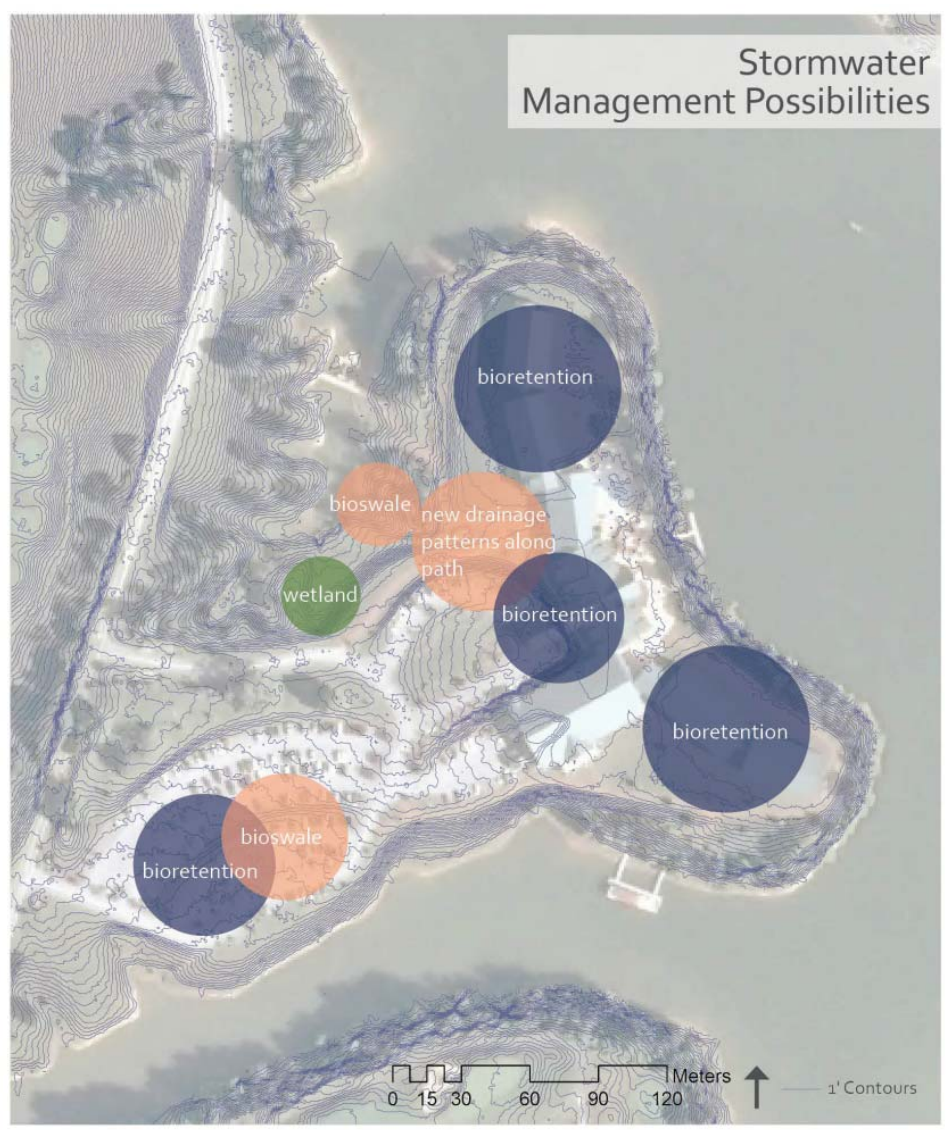


Each of these program layers are combined into one overlay which becomes the basis for the conceptual design layout (Fig. 22). Taking the stakeholders' and additional program elements into account, the space begins to be defined. The connections and relationships of each program element are critical for the success of the design, therefore making the following conceptual process key to design's success. The conceptual design combines sustainable stormwater practices with educational opportunities, and program expansion while creating functional circulation enhancements. These concepts must now be combined with the design concept.

Figure 22. Program Overlay Map

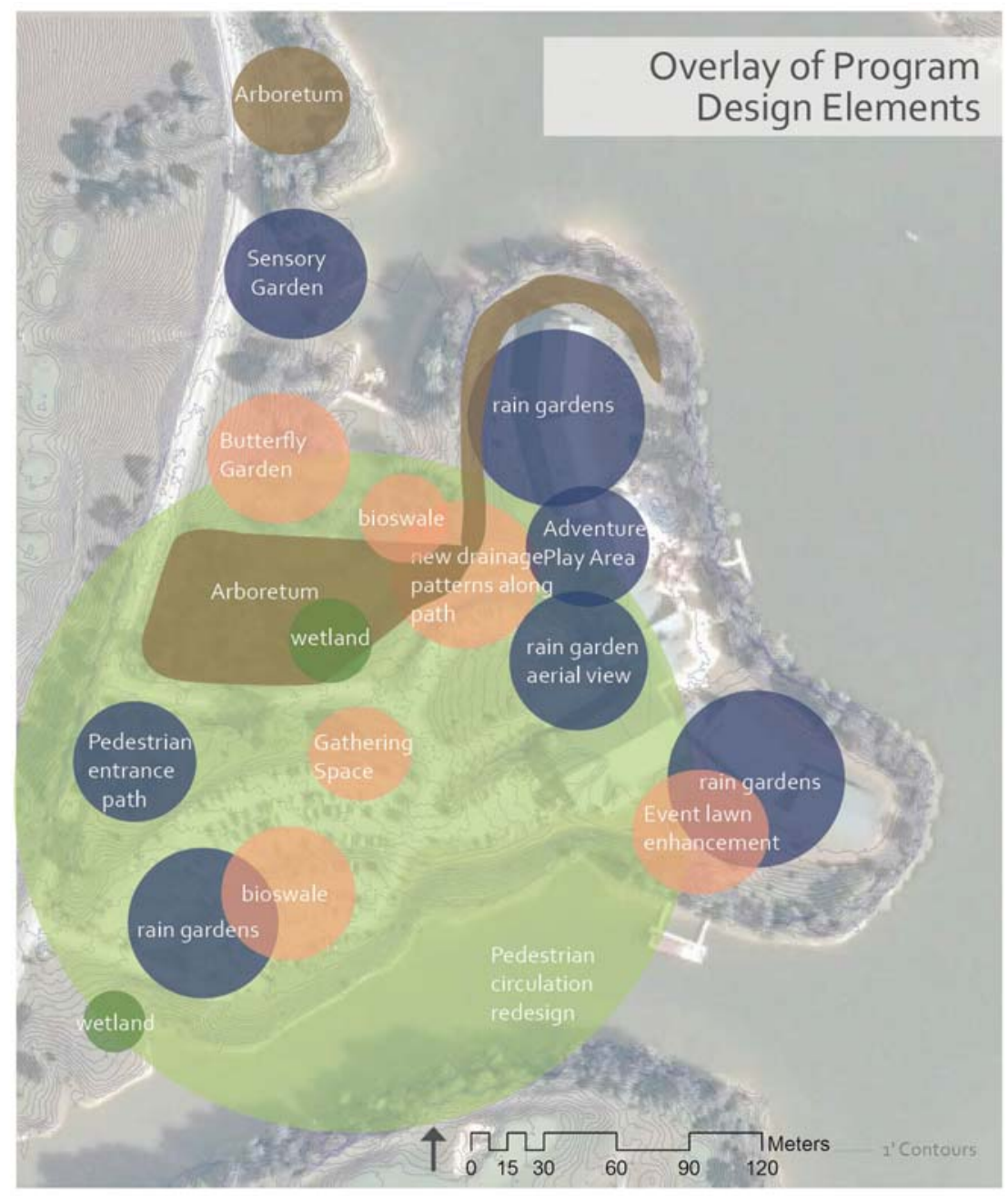


The project site is unique in that it has two different identities to recent generations, that of the state park, and that of the former town of Roanoke. In developing a design concept, both identities were analyzed and recognized. The West Virginia State Parks and Forests mission statement highlights several goals that are important in design formation including: providing outdoor recreation opportunity, creating a travel destination, encouraging picnics, retreats, and get-togethers, protect watersheds, provide wildlife habitat, hunting and fishing opportunities, nature program events and numerous environmental benefits. Each of these goals create a place where people and nature meet (WV State Parks, 2009).

Several cultural references are integrated in the design concept. As mentioned in the cultural analysis, there was a strong sense of order in Roanoke as seen through the pattern of the orchard, the farmland, the pasture and the social organization of day to day activities. The Roanoke community had a strong central hub where the people would meet and gather. Socialization brought the community close together whether it be through outdoor games, indoor meetings, or family picnics. Order, destination and social interaction are recognized as key conceptual components of the Roanoke community for design development.

In combining both identities of the project site the concept becomes a juxtaposition of nature and order, and a juxtaposition of socialization and relaxation. The design becomes a balance of organic patterns of the fluid water and mountainous landscape intersecting with the patterns of cultural order, while providing intimate spaces for reflection and retreat as well as areas for small events and activities. The design creates a space with natural tendencies that emphasize rainwater and native vegetation, while giving reference to the landscape's history and developing an educational experience for all. 
Following the development of the design concept, hydrologic, topographic and functional design concepts were developed to shift from conceptual ideas to working designs. The technical portions of the design include stormwater management and grading. The steep topography of the site strengthens stormwater management systems while challenging path construction. The first order for design is stormwater management, as it is the foundation of the entire design.

\section{CHAPTER 11: Stormwater Management}

The hydrologic analysis serves as the basis for stormwater management design throughout the project site. Bioretention cells, bioswales and constructed wetlands are used to collect, infiltrate and treat stormwater on site. Bioretention cells were the first stormwater management to be sized as they "serve highly impervious drainage areas less than two acres in size” such as rooftops and pavement (VADCR, 2011). These areas pond between six to twelve inches of runoff in a storm event, filtering the water and collecting runoff pollutants. The filter bed, a mixture of sand, soil and organic material, functions as the primary filtering component of bioretention.

"Bioretention creates a good environment for runoff reduction, filtration, biological uptake, and microbial activity, and provides high pollutant removal. Bioretention can become an attractive landscaping feature with high amenity value and community acceptance (VADCR, 2011).”

In designing bioretention on the project site, Chesapeake Stormwater Network provides two different levels for reducing runoff volume and nutrient removal. Level 2, an enhanced design, maximizes the reduction of runoff volume by $80 \%$ and nutrient removal with a deeper filter media depth than Level 1; therefore, Level 2 allows more runoff to enter the bioretention and 
increases the opportunity for pollutant removal (VADCR, 2011). The sizing of bioretention is "based on the computed Treatment Volume $\left(\mathrm{T}_{\mathrm{v}}\right)$ of the contributing drainage area and the storage provided in the facility” (VADCR, 2011). The Level 2 design includes a six inch surface ponding depth and a twelve inch gravel layer which is used in computing the equivalent storage depth. The following accepted Void Ratios $\left(\mathrm{V}_{\mathrm{r}}\right)$ are multiplied by the depth of media, gravel and surface ponding:

Biorention Soil Media $V_{r}=0.25$

Gravel $V_{r}=0.40$

Surface Storage $V_{r}=1.0$

The design storage depth used for Level 2 Bioretention equals 1.65' as found in the following equation using the Void Ratios:

$\left(3^{\prime}\right.$ Bioretention Soil Media x 0.25) + (1' Gravel x 0.40) $+\left(0.5^{\prime}\right.$ Surface Storage x 1.0) $=1.65^{\prime}$ The design storage depth is then used to find the design surface area (SA) of each individual bioretention cell. The equation used in the Chesapeake Stormwater Network design is: $S A\left(f t^{2}\right)=\left[\left(1.25 \times T_{v}\right)-\right.$ the volume reduced by upstream BMP $] / 1.65^{\prime}$ (Fig. 23).

Where:

$$
\begin{aligned}
& S A=\text { Minimum surface area of bioretention filter }\left(\mathrm{ft}^{2}\right) \\
& T_{v}=\text { Treatment Volume }\left(\mathrm{ft}^{3}\right)=\left[(1.0 ”)\left(\mathrm{R}_{\mathrm{v}}\right)(\mathrm{A}) / 12\right]
\end{aligned}
$$

(NOTE: $\mathrm{R}_{\mathrm{v}}=$ the composite runoff coefficient from the Rational Method) 
Figure 23. Parking Lot Bioretention Cross-Section

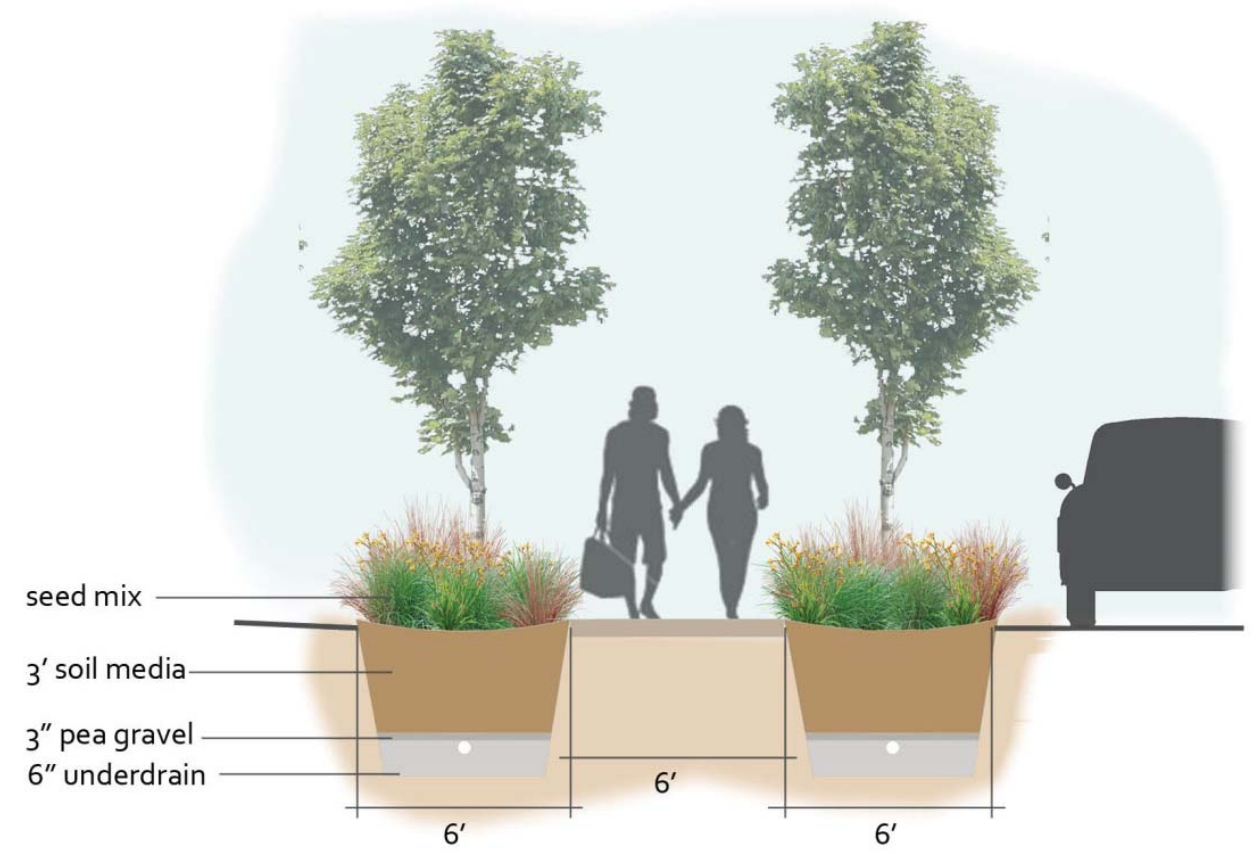

In solving for the Area for the Tv, the subwatershed delineation map from the hydrologic analysis was used. Each subwatershed's area was calculated to then be used to determine the surface area of bioretention cells required (Fig. 24). Bioretention cells were designed surrounding the lodge, within the parking lot and along the roads with surface area totaling 8,350 $\mathrm{ft}^{2}$ and total volume of $13,778 \mathrm{ft}^{3}$ (Fig. 25). The existing roofs collect stormwater in gutters which are then piped directly into the lake. The design of the bioretention cells will implement the disconnection of the pipes that will allow stormwater to enter stormwater management structures. Various bioretention cells are designed for the existing parking lot. Within each subwatershed in the parking lot, bioretention cells were sized to replace one to two parking spaces, which resulted in a total of thirty-eight parking spaces removed. The streetscape along the driveway into the lodge and main road through the state park is enhanced with bioretention cells dividing the road and sidewalk (Fig. 26). These cells not only collect stormwater runoff, but also serve as a safety barrier and aesthetic improvement for the pedestrian. 
Figure 24. Bioretention Subwatershed Delineation Map

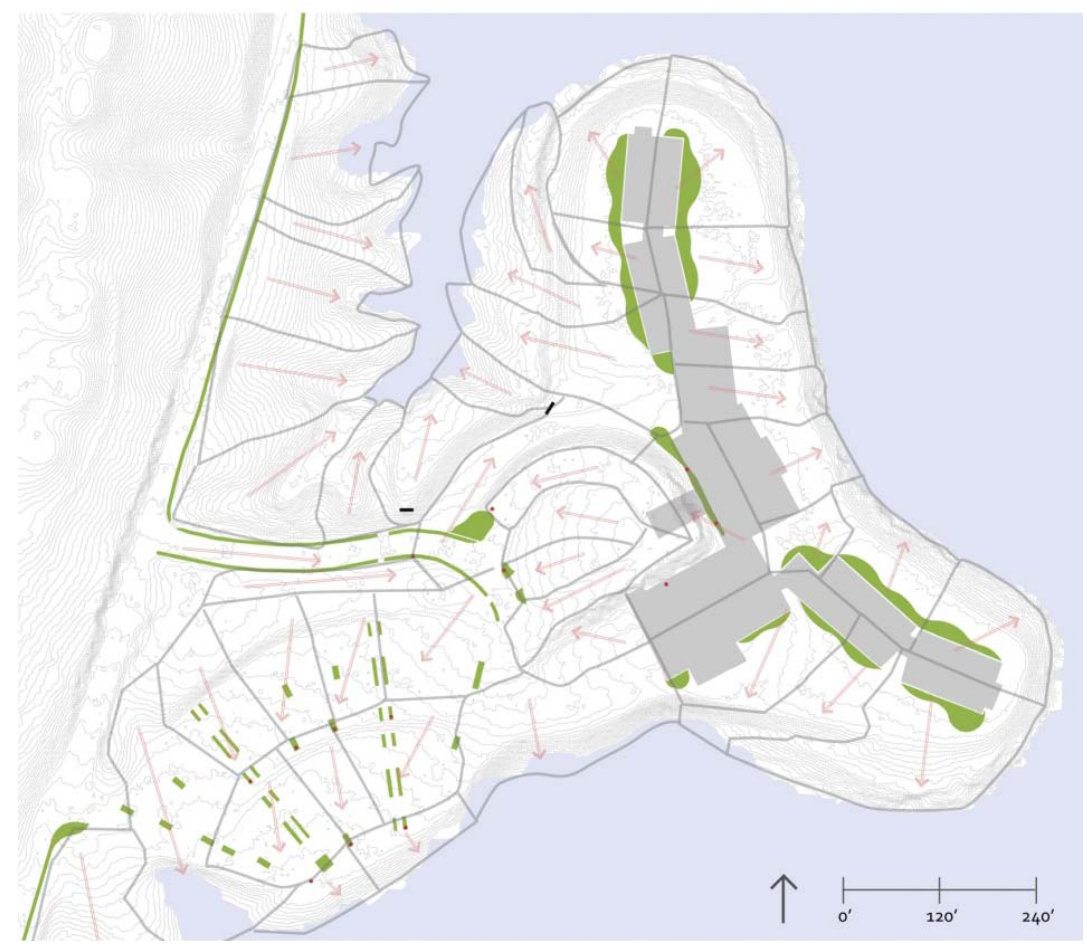

Figure 25. Designed Bioretention Cells Map

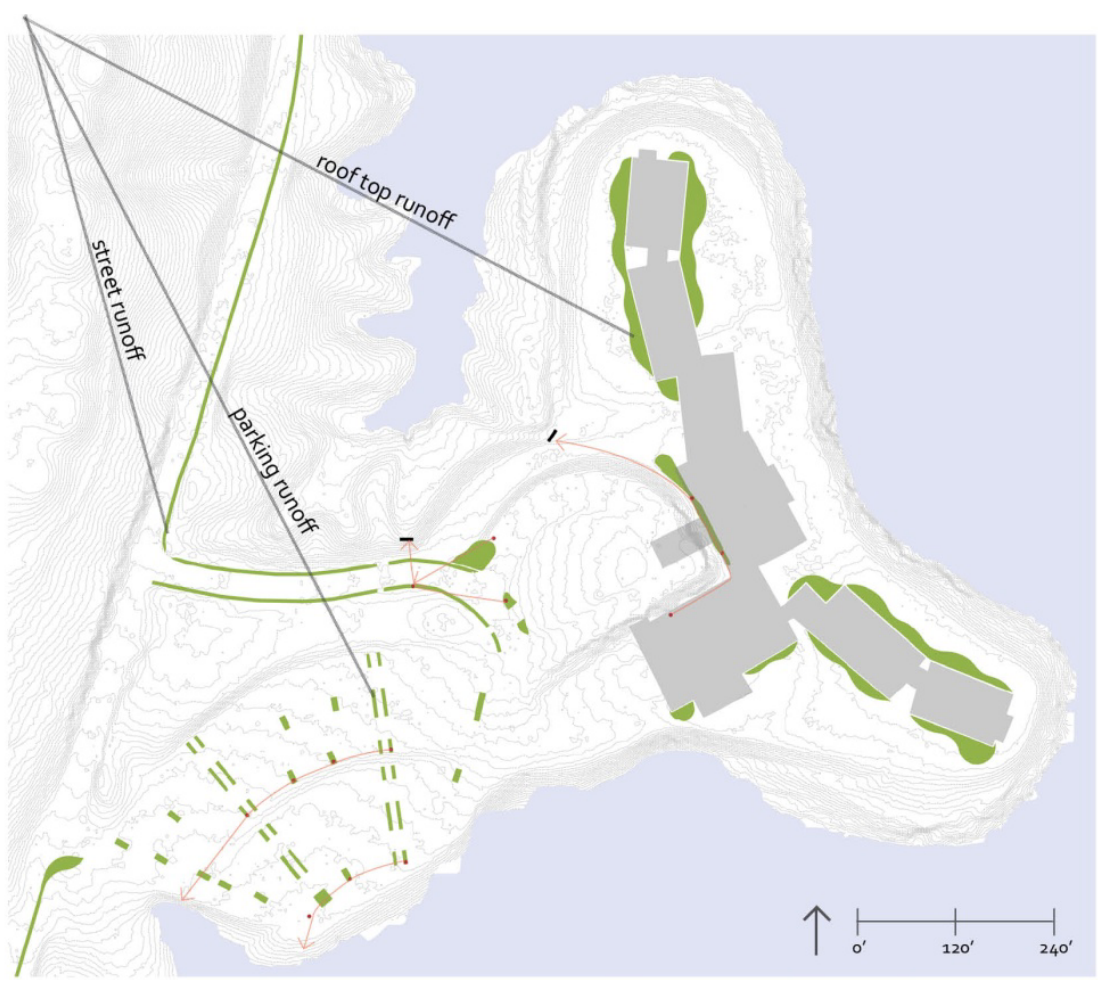


Figure 26. Typical Streetscape Enhancement

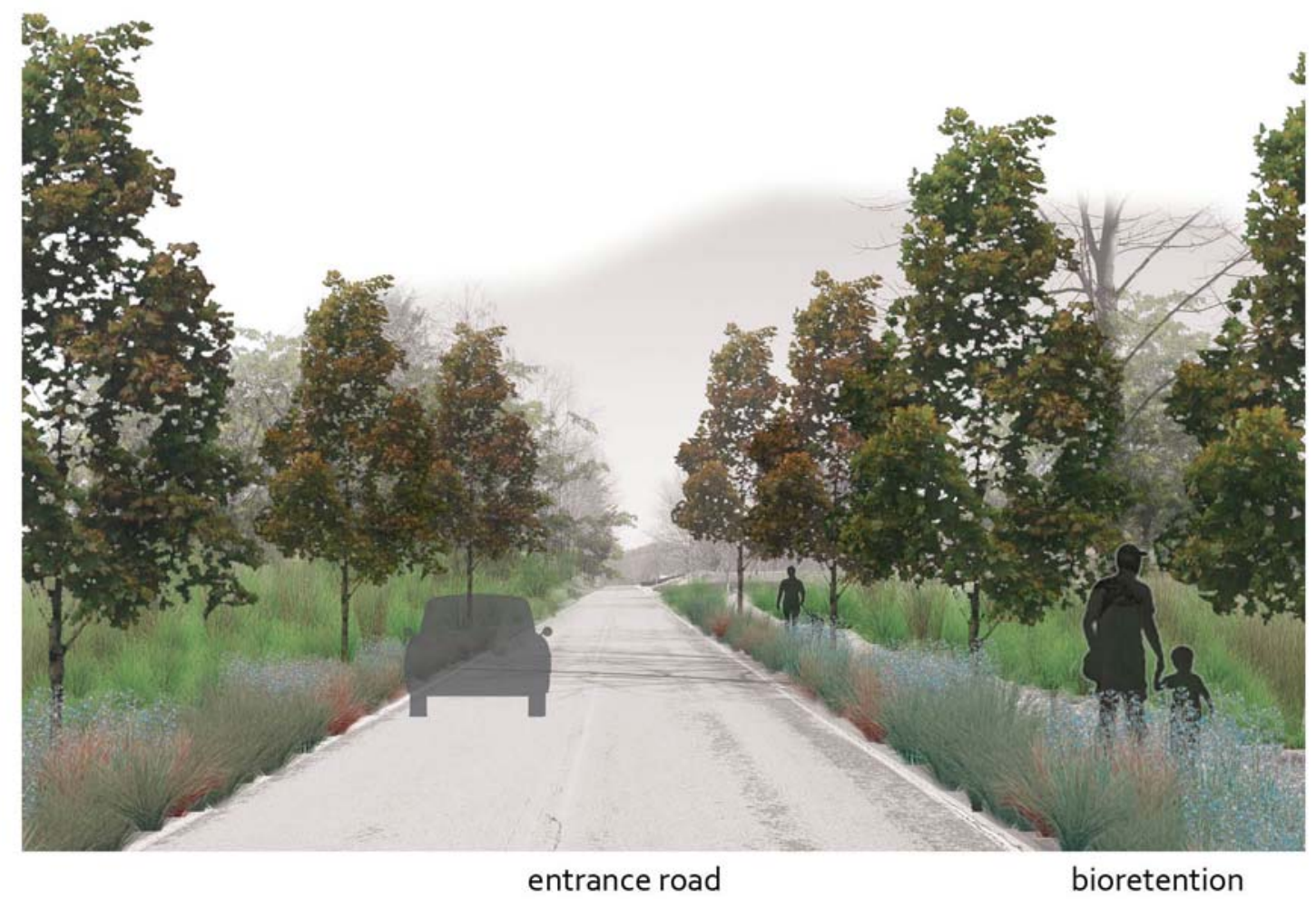

Two areas within the project site where severe erosion and sedimentation occur as a result of stormwater runoff were found to be most suitable for bioswale stormwater management (Fig. 27). Bioswales convey and store stormwater runoff which helps to slow and control the runoff. Slopes between one and six percent allow water to infiltrate where vegetation uptakes nutrients. The bioswales will also control the conveyance of stormwater runoff while reducing the amount of sedimentation and erosion that currently occur on site. The EPA Design Standards for bioswales involve finding the design flow rate, design volume and design area. The design flow rate (Q) takes into account the area, intensity based on a 10 year storm event, the surface type of the drainage area, and discharge. Once Q is found, the bioswales design volume is solved using the following equation: 


$$
V=\left[(1.486 / n) \times R^{2 / 3} \times S^{1 / 2}\right.
$$

Where:

$$
\begin{aligned}
& \mathrm{V}=\text { permissible } \mathrm{V}, 1.5 \mathrm{ft} / \mathrm{s} \\
& \mathrm{n}=\text { roughness coefficient, } 1.5 \mathrm{ft} / \mathrm{s} \\
& \mathrm{S}=\text { slope } \\
& \mathrm{R}=\text { permissible wetted perimeter }
\end{aligned}
$$

Then with knowing both $\mathrm{Q}$ and $\mathrm{V}$, the design area can be computed by using the equation $\mathrm{Q}=\mathrm{AV}$. The total volume of the two bioswales is $2,112 \mathrm{ft}^{3}$ with an average width of four to six feet (Fig. 28). The steep topography at the site of the bioswales resulted in an average sixpercent slope. In order to keep within the required slope range, stone cascades of two to three feet were designed to fit the bioswales into the topography. These cascades increase oxygenation while also creating an aesthetic amenity.

Figure 27. Designed Bioswales Map

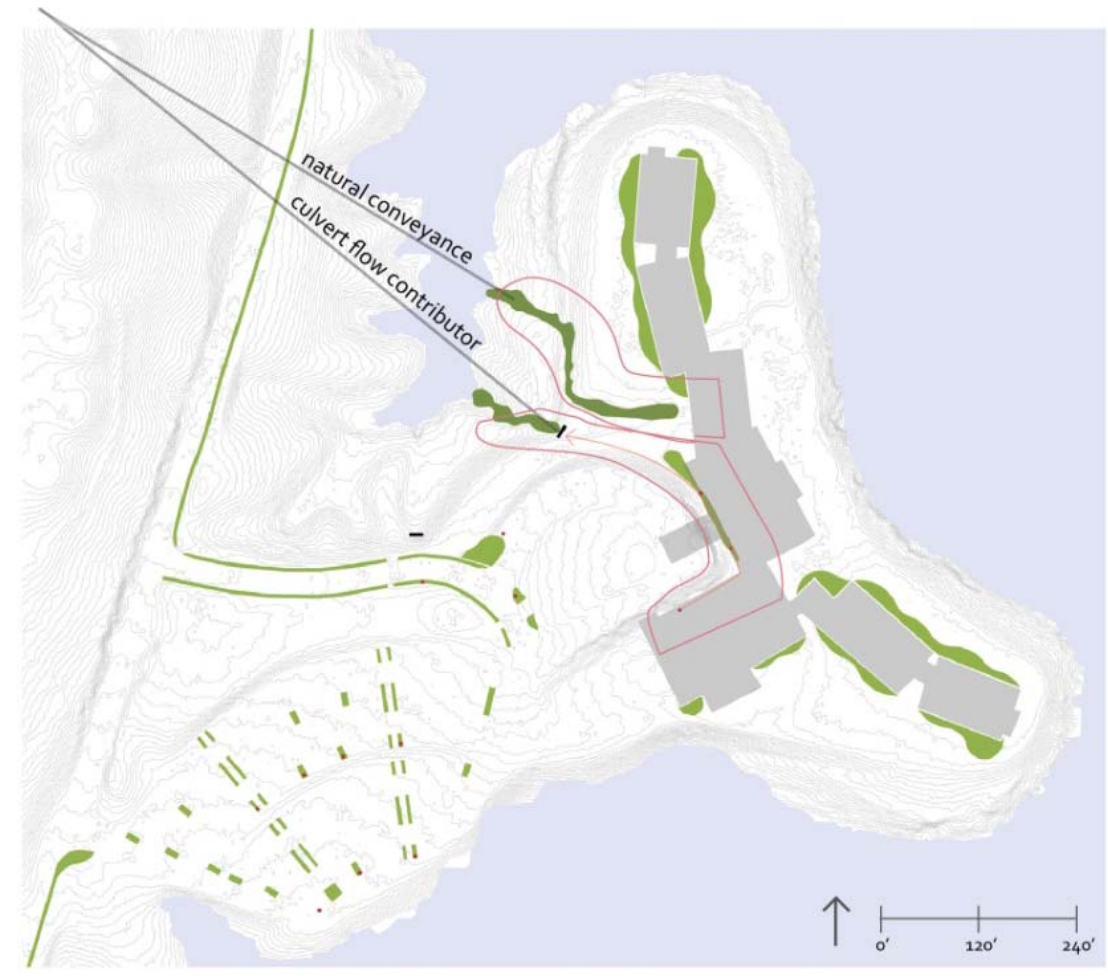


Figure 28. Bioswale Cross-Section

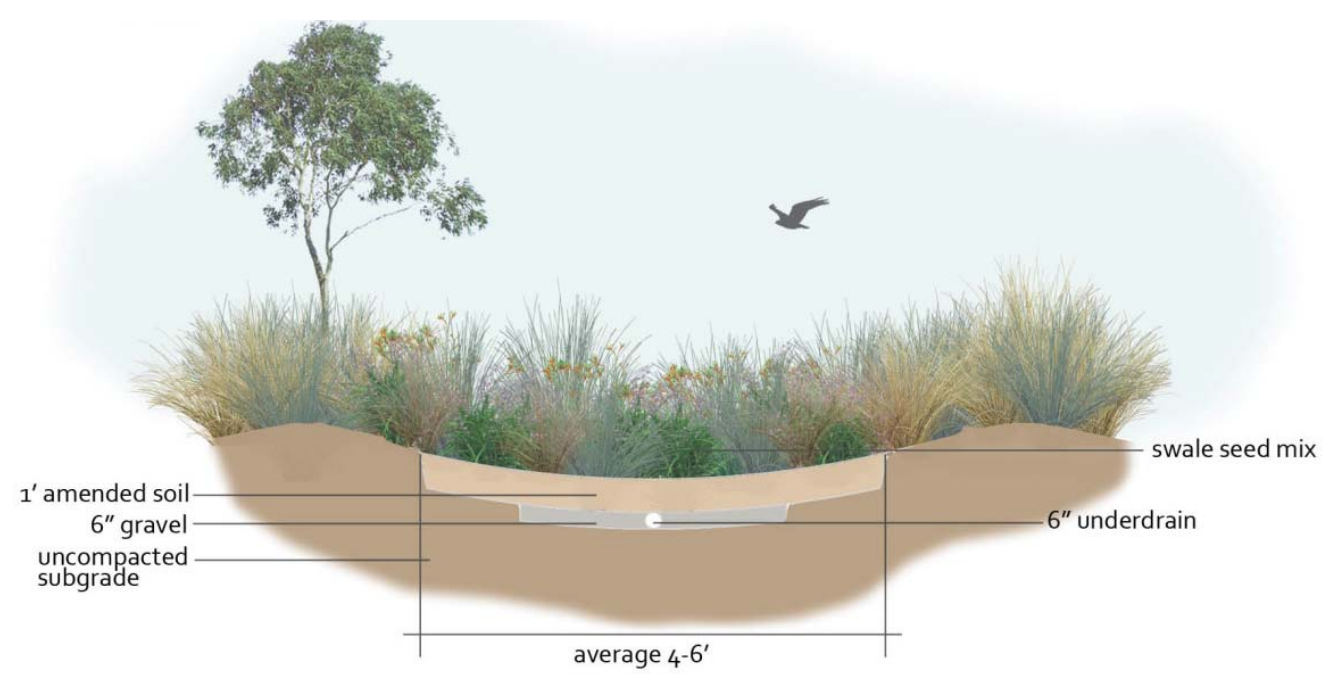

The last of the rooftop to stream sequence of stormwater management is constructed wetlands which "provide an ideal environment for gravitational settling, biological uptake, and microbial activity” (VADCR, 2011). One enhanced wetland is proposed within the project site, where there are existing wetland conditions (Fig. 29). The Chesapeake Stormwater Network design method was used to size the enhanced wetland. Similar to the bioretention design, the enhanced wetland also has two different design levels. The level 2 method removes seventy-five percent phosphorous and requires a minimum pooling depth of twenty-two inches (VADCR, 2011). In order to size a single cell wetland, the $T_{v}$ must be determined using the same equation as for the bioretention cell. From the $\mathrm{T}_{\mathrm{v}}$, required percentages for specific elements of the wetland are divided to equal one-hundred percent. For the wetland in this project, the percentages of $\mathrm{T}_{\mathrm{v}}\left(7,920 \mathrm{ft}^{3}\right)$ are divided as follows: 15\% sediment forebay, 5\% deep pool, $75 \%$ wetland cell, and 5\% micropool outlet (Fig. 30). With the bioretention cells along the street and near the lodge entrance, the $T_{v}$ was reduced by $1,017 \mathrm{ft}^{3}$. The sediment forebay is located at the major culvert that deposits into the wetland to collect sediments and "preserve the capacity of the main wetland treatment cell” (VADCR, 2011). This forebay has a maximum depth of four feet 
with a gradual upward slope to one foot where water overflows into the main wetland cell. The average depth of the wetland cell is twenty-two inches including one deep pool at two feet deep. The final deep pool of the wetland at two feet deep is the micropool outlet which is the discharge point into the lake (Fig. 31). This system completes the rooftop to stream treatment sequence, reducing sediments, uptaking nutrients, and enhancing the aesthetic appeal (Fig. 31). The vegetation of each stormwater management technique consists of various seed mixes. The bioretention cells use the stormwater seed mix, the bioswales use the swale seed mix, and the constructed wetlands use the stormwater, emergent wetland, and wetland edge seed mixes. The specific species and description of each seed mix will be discussed further in the vegetation section.

Figure 29. Enhanced Wetland Design

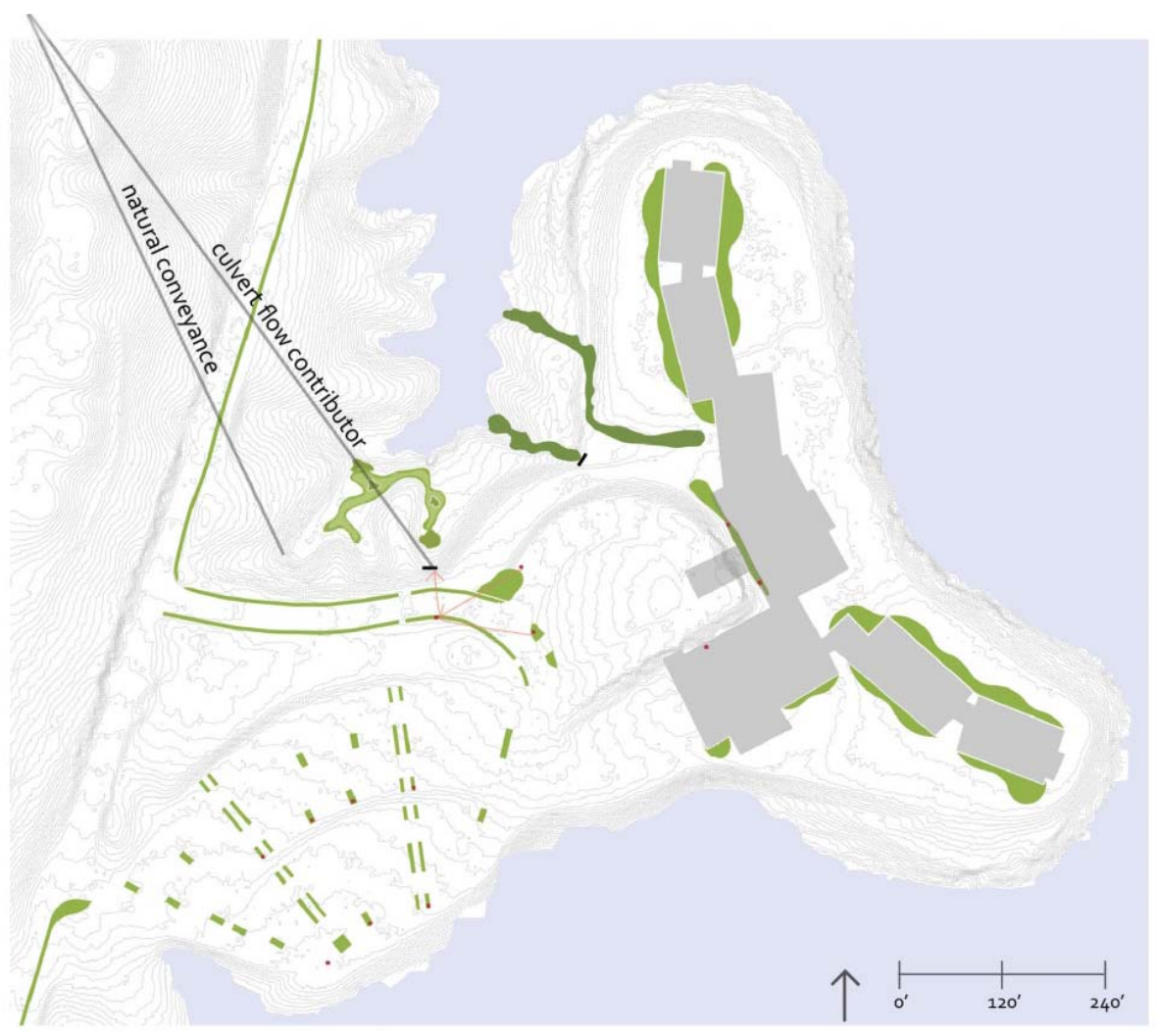


Figure 30. Total Volume Chart

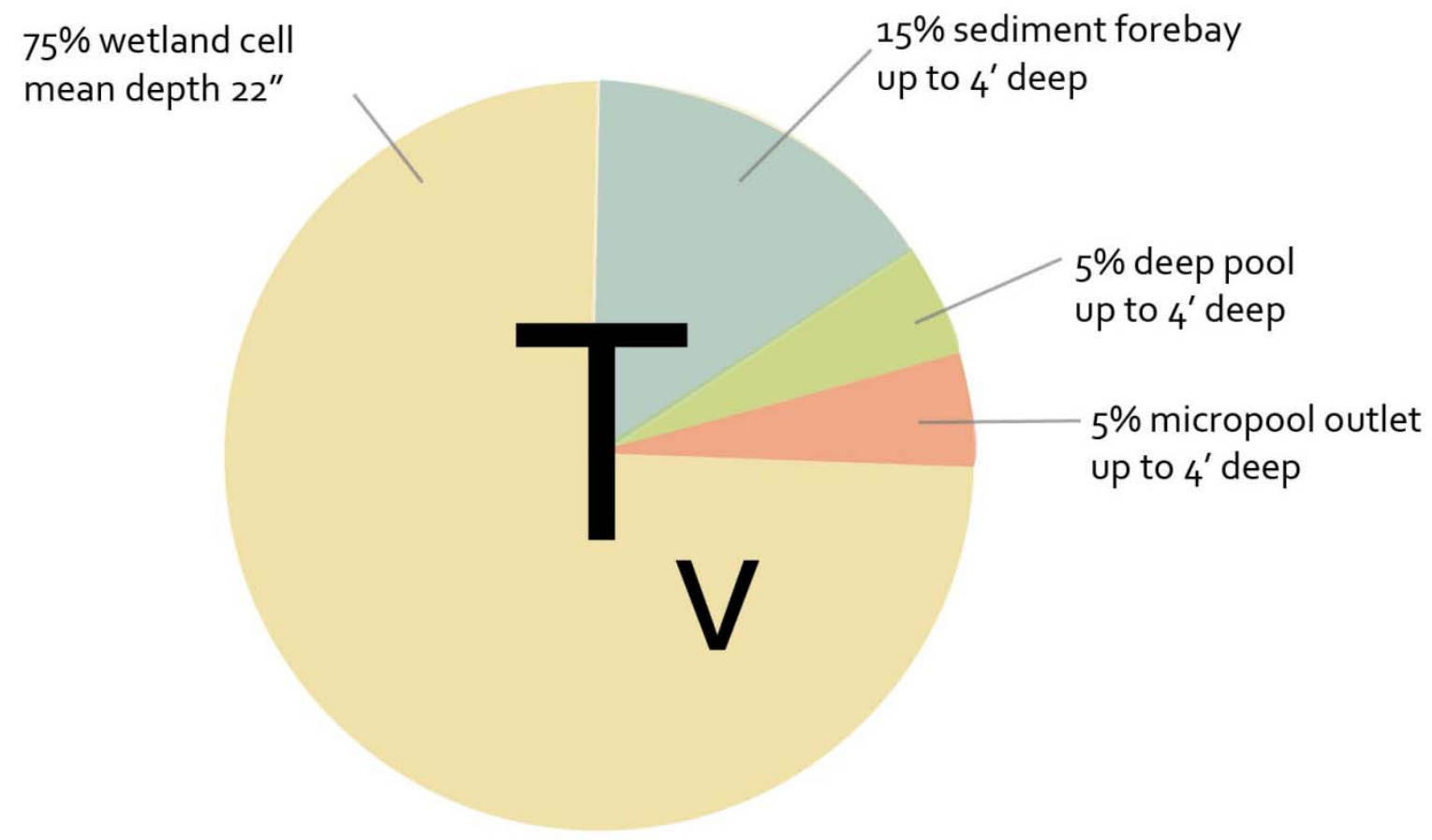

Figure 31. Enhanced Wetland Elements

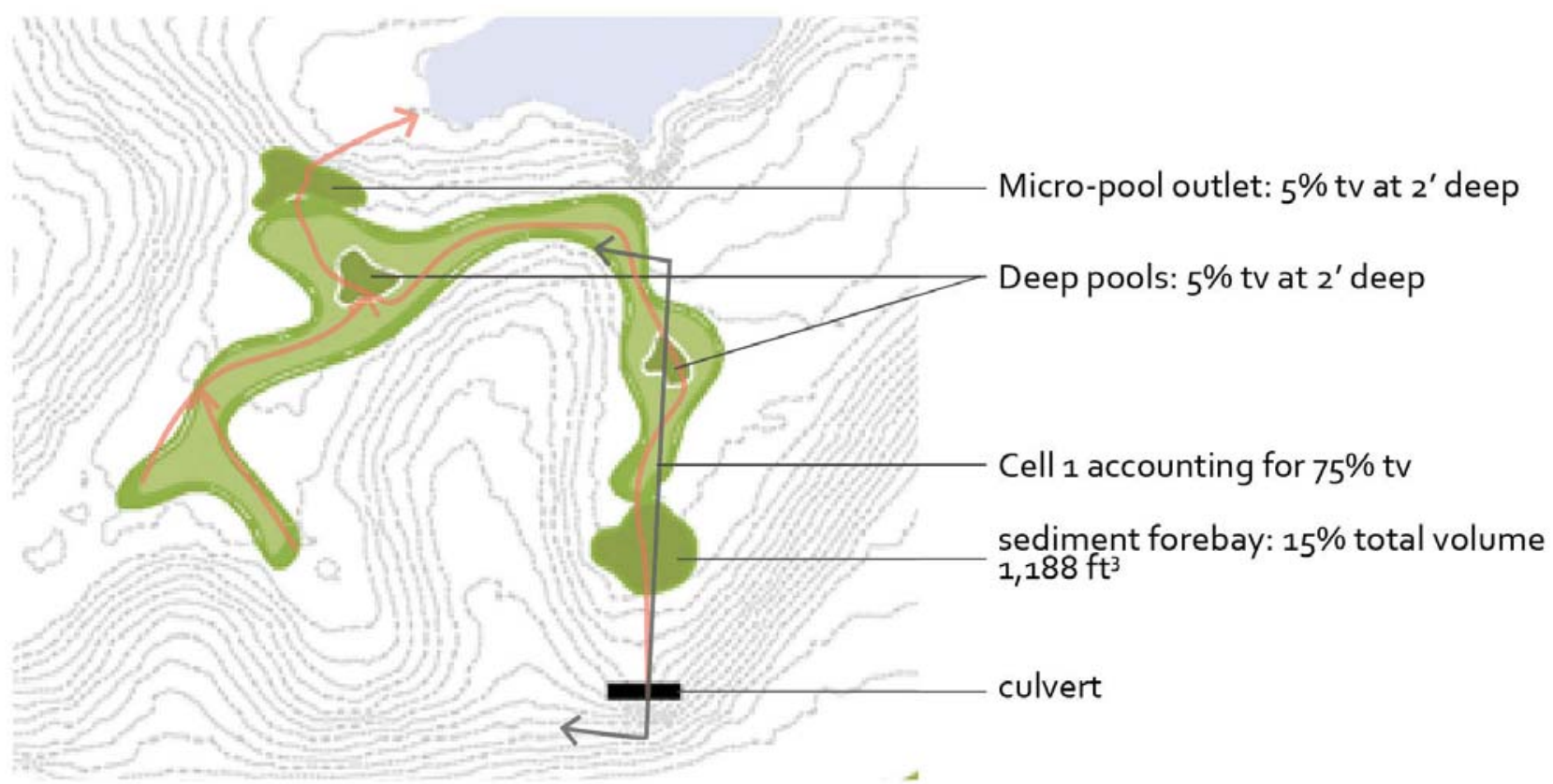




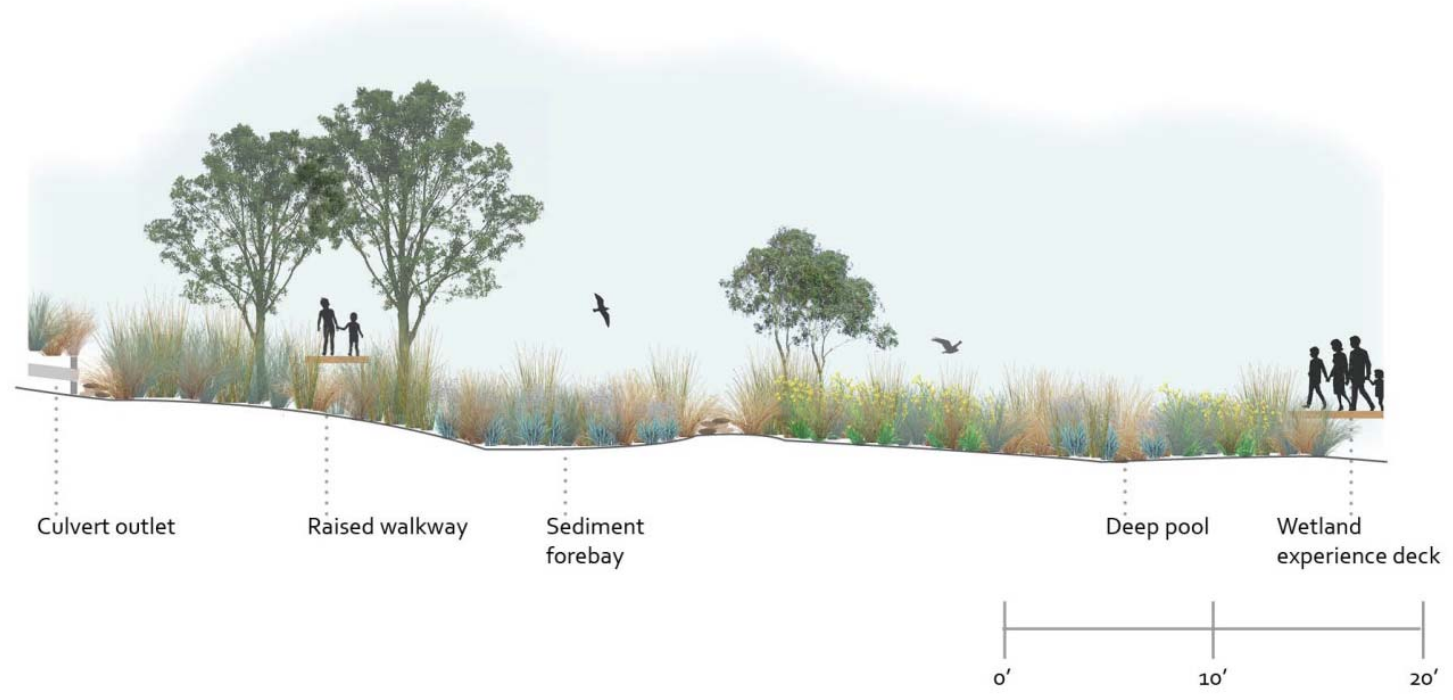

The specific design of stormwater management not only addresses water quality, but creates a system that links the hydrology on the entire site which in turn becomes an amenity (Echols, 2008). The SUDS urban drainage triangle links quantity, quality and amenity into one drainage system. This model has been used to develop the stormwater management on the peninsula. The rainwater becomes a highlighted part of the design that enhances the visitor experience by creating natural water features within a biodiverse habitat (Echols, 2008).

\section{CHAPTER 12: Grading}

Following the sizing and placement of the stormwater management, grading for the wetland, bioswales, bioretention and paths was tested, edited and finalized. The placement of the paths through the site was very dependent upon the existing topography and the amount of required earthwork. Also, the interaction of the stormwater management with the pedestrian played a key role in designing the paths (Fig. 33). The designed paths have a maximum slope of five percent, and ramps of eight percent include five-foot landings. The total cut of earthwork for the project is $363.12 \mathrm{ft}^{3}$ and the total fill is $336.71 \mathrm{ft}^{3}$ (Fig. 34). Beginning in the parking lot, two 
main pedestrian arteries brought people out of the automobile dominated asphalt lot to a safe walkway framed with bioretention cells. One artery required steps in order to return to grade with the least amount of earthwork, but the closer artery of the two to the lodge is accessible without stairs. A large portion of the cutting occurred with the placement of the bioswales. As explained in the stormwater section, the steep topography required earthwork to include the six percent slope and tie back to grade. The bioswales vary in width to not only slow and speed up the water but also to minimize the amount of earthwork needed to return to the existing grade.

Figure 33. Designed Path Map

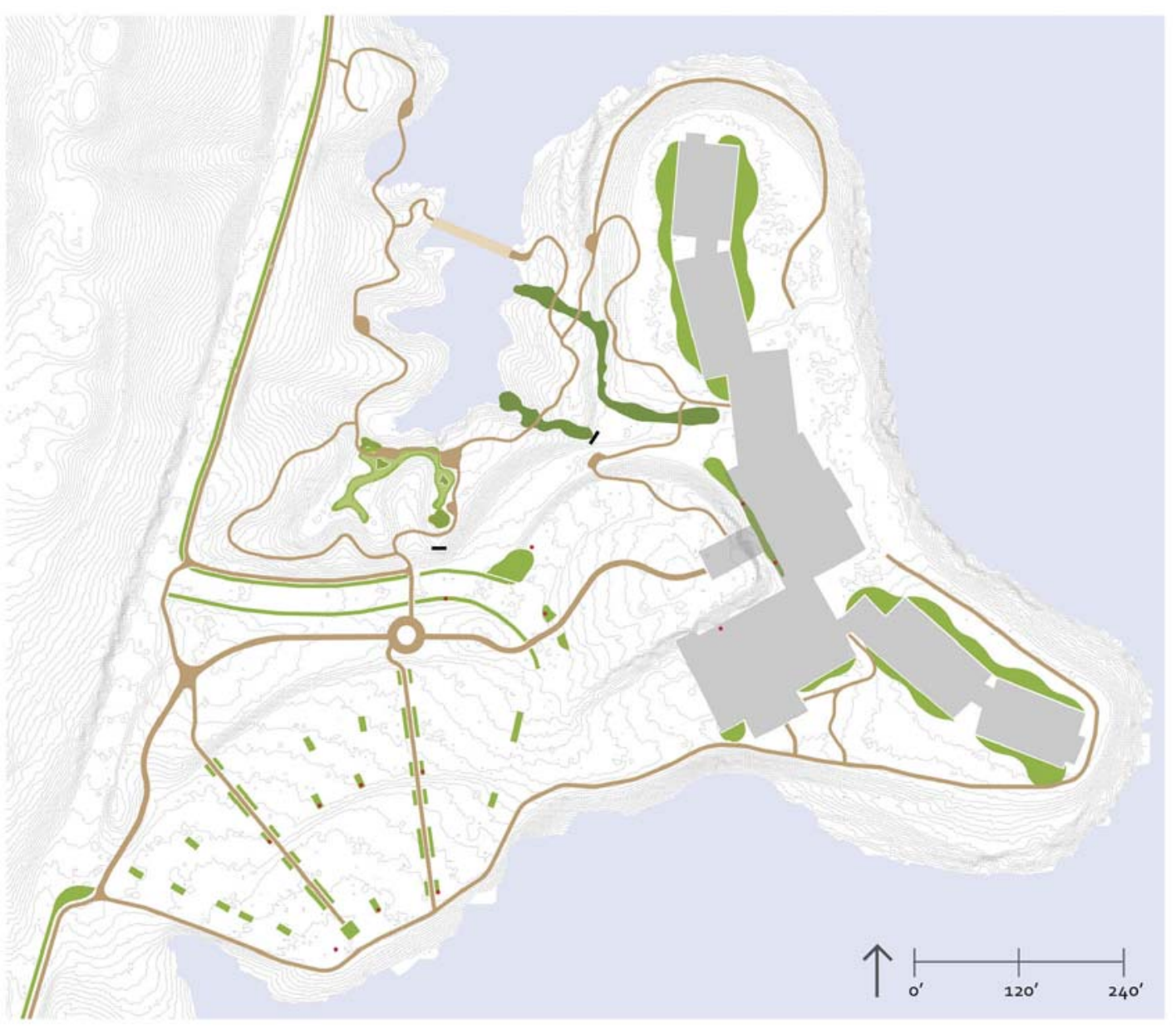


Figure 34. Grading Plan

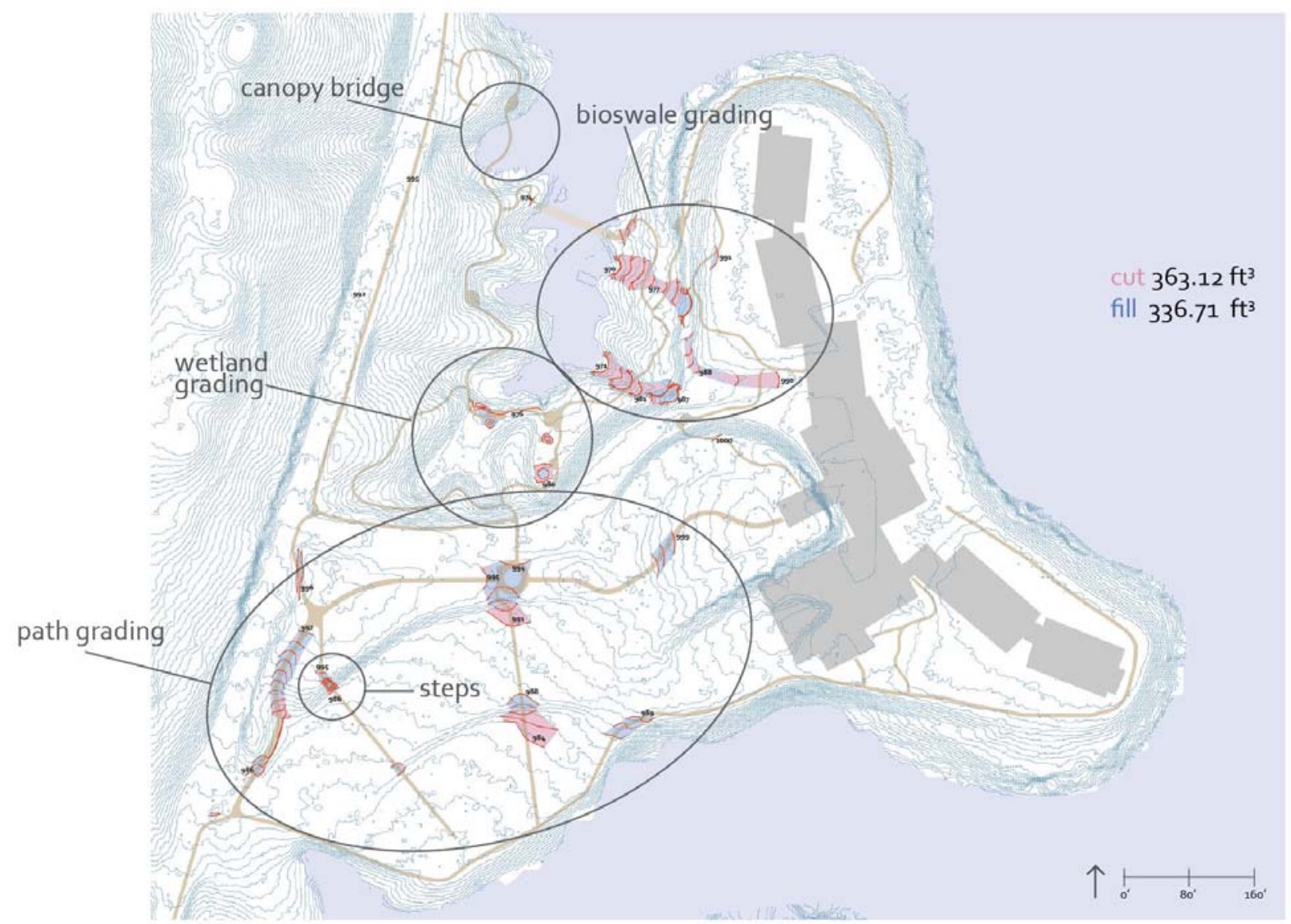

The challenges illustrated with the bioswales indicate the topographic issues found in placing paths through the park area. Numerous attempts were made to fit paths into the site within the slope range of $0-5 \%$, although this would require an enormous amount of high impact grading. Returning slopes to grade would have resulted in filling in areas of the lake. After realizing the amount of disturbance that would occur with paths in the park area, the decision to implement raised walkways was confirmed. Raised walkways reduce the impact on the land by fitting into the existing landscape and also allow vegetation to grow up around the path enveloping the pedestrian's experience. Approaching the most northern part of the park, where the slopes reach twenty-five percent, the decision was made to bring the raised pathway off the landscape and over a small inlet of water, creating a canopy bridge. This bridge in appearance 
will mimic the existing pedestrian bridge linking the lodge to the campground. The shallow waters and fluctuating water level during the year will permit trees to grow creating an interesting experience for the visitor, as they will view trees from a different perspective. The grading throughout the site addresses the circulation needs to create a cohesive and unified system, while also reducing the impact of development as much as possible by working paths and stormwater into the existing topography.

\section{CHAPTER 13: Vegetation}

The planting plan for the project site takes a naturalistic, low-maintenance and ecologically diverse identity. With the exception of the native forest area and the no-mow turf lawns, the proposed vegetation is a variety of seed mixes. This method of planting establishes native vegetation, increases water infiltration and stabilizes soil at the perimeter of the site. Seed mixes are selected for different zones on site based on specific habitats which consider wet and dry conditions, slope and sunlight (“Sustainable sites”, 2013). The variety of seed mixes not only creates an ecologically diverse habitat, but becomes an exciting and transitioning experience for the visitor. The planting zones and maintenance provide social and community engagement Height, color, texture and shape of the vegetation vary throughout the paths of the site. This map identifies the specific areas of each seed mix zone and illustrates the diversity of zones in response to the topography (Fig. 35, 36). The following table characterizes each seed mix (“Sustainable sites”, 2013) (Table 1). Tables 2-4 presents the list of species found in the various seed mixes (Tables 2, 3, 4). 
Figure 35. Seed Mix Zones

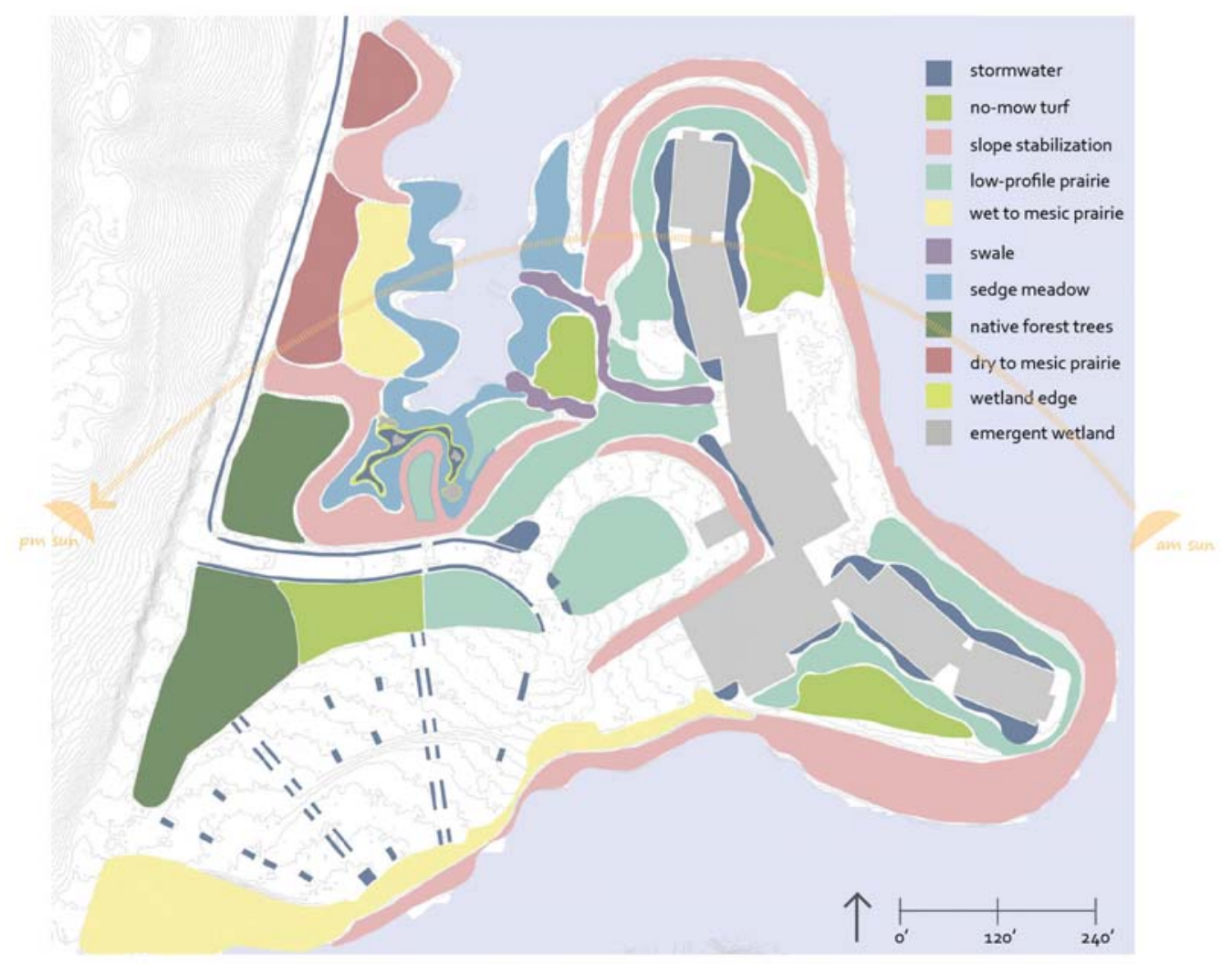

Figure 36. Seed Mix Cross-Section

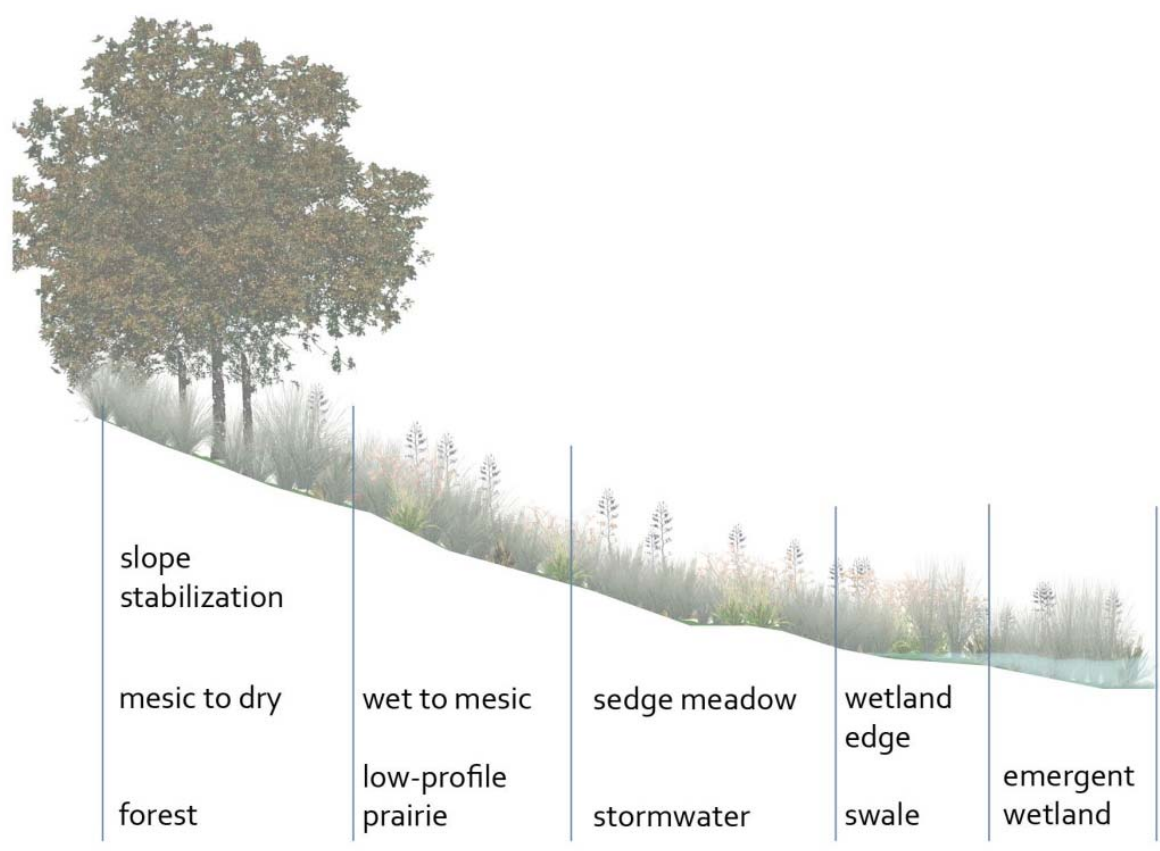


Table 1. Seed Mix Descriptions

\begin{tabular}{|l|l|}
\hline Mesic to Dry & $\begin{array}{l}\text { Prairie grasses and wildflowers } \\
\text { Short to tall } \\
\text { Diverse cover and food options for wildlife }\end{array}$ \\
\hline Wet to Mesic & $\begin{array}{l}\text { Prairie grasses and wildlflowers } \\
\text { Variety of color and texture }\end{array}$ \\
\hline Low Profile Prairie & $\begin{array}{l}\text { Prairie grasses and wildflowers } \\
\text { Average height }<\text { 4' } \\
\text { Variety of blooms from spring to fall }\end{array}$ \\
\hline Slope Stabilization & $\begin{array}{l}\text { Grasses and sedges } \\
\text { Used where erosion control is needed } \\
\text { Use with erosion-control materials }\end{array}$ \\
\hline Sedge Meadow & $\begin{array}{l}\text { Saturated soil conditions with dry tolerance } \\
\text { Offers cover and food options for wildlife } \\
\text { Attracts birds, butterflies and hummingbirds }\end{array}$ \\
\hline Swale & $\begin{array}{l}\text { Pollutant filter } \\
\text { Tolerant of temporary water detention }\end{array}$ \\
\hline Wetland Edge & $\begin{array}{l}\text { Stable, saturated soil conditions } \\
\text { Good water quality } \\
\text { Tolerant of 4” water depth }\end{array}$ \\
\hline Emergent Wetland & $\begin{array}{l}\text { Saturated soils and shallow water } \\
\text { Tolerant of up to 12” water } \\
\text { Stable wetlands and good water quality }\end{array}$ \\
\hline Stormwater & $\begin{array}{l}\text { Tolerates high fluctuating water levels and dry periods } \\
\text { Pollution tolerant }\end{array}$ \\
\hline
\end{tabular}


Table 2. Seed Mix Species List A

\begin{tabular}{|c|c|c|c|}
\hline Mesic to Dry & Wet to Mesic & Low Profile Prairie & Sedge Meadow \\
\hline \multicolumn{4}{|c|}{ Permanent Grasses and Sedges } \\
\hline Andropogan gerardii & Andropogan gerardii & Bouteloua curtipendula & Calamagrostis canadensis \\
\hline Bouteloua curtependula & Calamagrostis canadensis & Carex spp. & Carex comosa \\
\hline Carex spp. & Carex spp. & Elymus canadensis & Carex cristatella \\
\hline Elymus canadensis & Carex lurida & Koeleria cristata & Carex frankii \\
\hline Panicum virgatum & Elymus virginicus & Panicum virgatum & Carex lupilina \\
\hline Schizachyrium & Panicum virgatum & Schizachyrium scoparium & Carex lurida \\
\hline 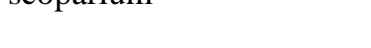 & Scirpus pendulus & & Carex stipata \\
\hline & Sorfhastrum nutans & & Cares vulpinoidea \\
\hline & Spartina pectinata & & Elymus virginicus \\
\hline & & & Glyceria striata \\
\hline & & & $\begin{array}{l}\text { Juncus effusus } \\
\text { Leersia oryzoides }\end{array}$ \\
\hline & & & Panicum virgatum \\
\hline & & & Scirpus atrovirens \\
\hline & & & Scirpus pendulus \\
\hline & & & Scirpus validus \\
\hline & & & Spartina pectinata \\
\hline \multicolumn{4}{|c|}{ Forbs and Shrubs } \\
\hline Anemone clylindrica & Aster novae-angliae & Anemone clylindrica & Alisma spp. \\
\hline Asclepias tuberosa & Baptistia lactea & Asclepias tuberosa & Angelica atropurpurea \\
\hline Aster laevis & Chamaecrista fasciculate & Aster ericoides & Asclepias incarnate \\
\hline Aster oolentangiensis & Coreopsis lanceolata & Aster laevis & Aster novae-angliae \\
\hline Baptisia lactea & Coreopsis tripteris & Aster novae-angliae & Aster puniceus \\
\hline Chamaecrista fasciculata & Desmondium illinoiense & Baptisia lacteal & Aster umbellatus \\
\hline Coreopsis lanceolata & Echinacea purpurea & Chamaecrista fasciculata & Bidens cernua \\
\hline Coreopsis palmata & Eryngium yuccifolium & Coreopsis lanceolata & Coreopsis tripteris \\
\hline Desmanthus illineonsis & Helenium autumnale & Coreopsis palmata & Eupatorium maculatum \\
\hline Desmondium illinoense & Helianthus grosseserratus & Dalea candida & Eupatorium perfoliatum \\
\hline Echinacea purpurea & Lespedeza captiata & Dalea purpurea & Helenium autumnale \\
\hline Eryngium yuccifolium & Liatris spicata & Echinacea purpurea & Hibiscus laevis \\
\hline Lespedeza capitata & Lupinus perennis & Eryngium yuccifolium & Iris virginica \\
\hline Liatris aspera & Monarda fistulosa & Lespedeza capitata & Liatris spicata \\
\hline Liatris pycnostachya & Parthenium integrifolium & Liatris aspera & Lobelia cardinalis \\
\hline Lupinus perennis & Physostegia virginiana & Lupinus perennis & Lobelia siphilitica \\
\hline Monarda fistulosa & $\begin{array}{l}\text { Pycnanthemum } \\
\text { virginianum }\end{array}$ & Monarda fistulosa & Lycopus americanus \\
\hline Parthenium integrifolium & Ratibida pinnata & Parthenium integrifolium & Penthorum sedoides \\
\hline Potentilla arguta & Rudbeckia hirta & Penstemon digitalis & Physostegia virginianum \\
\hline $\begin{array}{l}\text { Pycnanthemum } \\
\text { virginianum }\end{array}$ & Rudbeckia laciniata & $\begin{array}{l}\text { Pycnanthemum } \\
\text { virginianum }\end{array}$ & Polygonum spp. \\
\hline Ratibida pinnata & Rudbeckia subtomentosa & Ratibida pinnata & Pycnanthemum \\
\hline Rudbeckia hirta & Silphium integrifolium & Rudbeckia hirta & Sagittaria latifolia \\
\hline Silphium integrifolium & Silphium perfoliatum & Rudbeckia subtomentosa & Senna hebecarpa \\
\hline Silphium laciniatum & $\begin{array}{l}\text { Silphium } \\
\text { terebinthinaceum }\end{array}$ & Silphium integrifolium & Silphium perfoliatum \\
\hline Silphium & Solidago juncea & Silphium terebinthinaceum & Sparganium eurcarpum \\
\hline Solidago nemoralis & Solidago rugosa & Solidago nemoralis & Spirea alba \\
\hline
\end{tabular}




\begin{tabular}{|l|l|l|l|} 
Solidago rigida & Tradescantia ohioensis & Solidago rigida & Thalictrum dasycarpum \\
Solidago speciosa & Veronia spp. & Tradescantia ohioensis & Verbena hastata \\
$\begin{array}{l}\text { Vergicastrum } \\
\text { Zizinicum aptera }\end{array}$ & Veronicastrum virginicum & Veronia spp. & \\
\hline \multicolumn{2}{|l|}{ Temporary Cover } \\
\hline Avena sativa & Zizia aurea & Veronicastrum virginicum & \\
Lolium multiflorum & Avena sativa & Avena sativa & Avena sativa \\
\hline
\end{tabular}

Table 3. Seed Mix Species List B

\begin{tabular}{|c|c|c|c|}
\hline Swale & Wetland Edge & Emergent Wetland & Stormwater \\
\hline \multicolumn{4}{|c|}{ Permanent Grasses and Sedges } \\
\hline Andropogan gerardii & Carex comosa & Carex comosa & Carex cristatella \\
\hline Carex comosa & Carex cristatella & Carex lacustris & Carex lurida \\
\hline Carex cristatella & Carex frankii & Carex lurida & Carex vulpinoidea \\
\hline Carex lurida & Carex vulpinoidea & Carex vulpinoidea & Elymus virginicus \\
\hline Carex spp. & Eleocharis palustris & Eleocharis ovata & Glyceria striata \\
\hline Carex culpinoidea & Elymus virginicus & Leeria oryzoides & Juncus effusus \\
\hline Glyceria striata & Glyceria striata & Juncus effusus & Juncus torreyi \\
\hline Panicum virgatum & Leersia oryzoides & Scirpus acutus & Leersia oryzoides \\
\hline Scirpus atrovirens & Scirpus atrovirens & Scirpus pungens & Panicum virgatum \\
\hline Scirpus cyperinus & Scirpus cyperinus & Scirpus validus & Scirpus atrovirens \\
\hline Scirpus pectinata & Scirpus pungens & & Scirpus cyperinus \\
\hline & Scirpus validus & & Scirpus fluviatilis \\
\hline & Sparganium eurycarpum & & Scirpus validus \\
\hline \multicolumn{4}{|c|}{ Forbs and Shrubs } \\
\hline Alisma spp. & Acorus calamus & Acorus calamus & Alisma spp. \\
\hline Asclepias incarnata & Alisma spp. & Alisma spp. & Asclepias incarnata \\
\hline Aster novae-angliae & Asclepias incarnata & Asclepias incarnata & Bidens spp. \\
\hline Coreopsis tripteris & Aster puniceus & Cephalanthus occidentalis & Helenium autumnale \\
\hline Eupatroium maculatum & Bidens spp. & Decodon verticillatus & Lycopus americanus \\
\hline Iris virginica & Eupatorium perfoliatum & Euphatorium macalatum & Mimulus ringens \\
\hline Liatris spicata & Helenium autumnale & Hibiscus spp. & Penthorum sedoides \\
\hline Lobelia cardinalis & Iris virginica & Iris virginica & $\begin{array}{l}\text { Polygonum } \\
\text { penslyvanicum }\end{array}$ \\
\hline Lobelia siphilitica & Lobelia siphilitica & Lobelia cardinalis & Rudbeckia subtomentosa \\
\hline Lycopus americanus & Lycopus americanus & Lobelia siphilitica & Sagitarria latifolia \\
\hline Sagitarria latifolia & Mimulus ringens & Lycopus americanus & Senna hebecarpa \\
\hline Silphium & Penthoum sedoides & Mimulus ringens & Thalictrum dasycarpum \\
\hline terebinthiniaceum & & & \\
\hline Verbena hastata & Polygonum spp. & Peltandra virginica & \\
\hline Zizia aurea & Rudbeckia laciniata & Penthoum sedoides & \\
\hline & Sagittaria latifolia & Polygonum spp. & \\
\hline & & Ponterderia cordata & \\
\hline & & Sagitarria latifolia & \\
\hline & & Sparganium americanum & \\
\hline & & Sparganium eurycarpum & \\
\hline & & Verbena hastata & \\
\hline \multicolumn{4}{|c|}{ Temporary Cover } \\
\hline Avena sativa & Avena sativa & Avena sativa & Avena sativa \\
\hline Lolium multiflorum & Lolium multiflorum & Lolium multiflorum & Lolium multiflorum \\
\hline
\end{tabular}


Table 4. Seed Mix Species List C

\begin{tabular}{|l|}
\hline Slope Stabilization \\
\hline \multicolumn{1}{|c|}{ Permanent Grasses and Sedges } \\
\hline Andropogan gerardii \\
Bouteloua curtipendula \\
Carex spp. \\
Elymus Canadensis \\
Elymus virginicus \\
Panicum virgatum \\
Schizachrium scoparium \\
Sorghastrum nutans \\
\hline \multicolumn{1}{|c|}{ Temporary Cover } \\
\hline Avena sativa \\
Lolium multiflorum \\
\hline
\end{tabular}

In addition to the seed mix zones, a signature plant palette was selected to give a unique identity to the site. Specific species of trees, shrubs, grasses and forbs are seen throughout each of the design spaces, creating continuity and unity within the planting plan. The species will be used in different forms, from masses to single plants, giving visitors the opportunity to view the same species from different perspectives. The signature trees include Acer rubrum (Red Maple), Quercus palustris (Pin Oak), and Cornus florida (Flowering Dogwood), all of which are native to central West Virginia. Acer rubrum grows into a large shade tree with showy red and yellow fall foliage. Its adaptability to most soils provides the suitability for the entire site. Quercus palustris, a hardy and fast growing lawn tree, provides dark red fall foliage that persists through the winter months for multi-season interest. A smaller flowering tree, Cornus florida, shows fragrant white and pink flowers in the spring, and bright red fruit and foliage in the fall. Each of these trees attracts birds and butterflies for habitat (Shaw, Schmidt, 2003). The shrubs selected include Spiraea alba (White Sweetmeadow), Ilex verticillata (American Winterberry), and Viburnum trilobum (American Cranberrybush) each providing unique characteristics to the plant palette. Spiraea alba is a small mound-shaped woody shrub that blooms tiny white flowers in terminal spikes. The shrub prefers wet soils, making it very adaptable in both stormwater and 
water's edge areas. Ilex verticillata , a deciduous holly, grows over six feet in height with iconic clusters of red berries that persist through winter. The shrub is adaptable to both moist and dry soils. A large round deciduous shrub, Viburnum trilobum, offers seasonal interest with white blooms in early summer, reddish purple fall foliage, and persistent red fruit. This shrub prefers moist soils, and is adaptable to stormwater management uses (Shaw, Schmidt, 2003).

The three signature grasses selected are Schizachyrium scoparium (Little Bluestem), Andropogan gerardii (Big Bluestem), and Calamagrostis canadensis (Bluejoint). Schizachyrium scoparium, a fine-textured ornamental bunch grass, grows only two to three feet tall. This dry tolerant grass is characterized by its blue-green stems in season and mahogany-red fall foliage. The perennial bunch grass, Andropogan gerardii, grows up to eight feet tall in mesic conditions. Similar to Schizachyrium scoparium, Andropogan gerardii grows blue-green stems turning a maroon-tan in the fall. Calamagrostis canadensis prefers moist to wet soils and reaches five feet in height. The grass becomes purple when it flowers then turning to tan. Growing among the grasses, the four forbs selected for the signature palette include Aster puniceaus (Purplestem Aster), Liatris spicata (Dense Blazing Star), Pycnanthemum virginianum (Mountain Mint), and Ratibida pinnata (Yellow Coneflower). Aster puniceaus grows up to eight feet tall in moist to wet soils. Its bluish purple flowers bloom in the early fall attracting butterflies. Liatris spicata, a small herbaceous perennial, grows upright purple-red blooms in late summer. This forb prefers mesic to dry conditions and attracts birds and butterflies. Pycnanthemum virginianum grows in mesic to wet conditions and only reaches three feet in height. The white blooms during the summer provide a mint fragrance and can be used for making teas. Ratibida pinnata, an herbaceous perennial, matures at three to five feet and thrives best in masses and mesic conditions. The distinctive yellow blooms appear in late summer attracting butterflies and birds 
(Shaw, Schmidt, 2003). Each of the species in the signature palette will be seen throughout the project and will be highlighted again with the detailed description of each space in the following sections.

\section{CHAPTER 14: Master Plan}

Following the processes of finalizing stormwater management, grading, and planting zones, the spaces within the site were formed. The final master plan is designed to create spaces within and around stormwater management while taking visitors through various experiences within the site. Forested allees, open meadows and prairies, vast raised overlooks, social spaces, play areas, and numerous educational opportunities encompass this eighteen acre area (Fig. 37). Visitors coming to the site via automobile or on foot will be engaged with stormwater and new circulation patterns from the entrance leading pedestrians into different spaces and experiences. With moving to the detailed design of the park, it is important to revisit the stakeholders' program element desires and illustrate how those were addressed in the master plan. The stakeholders' desired an arboretum to provide educational opportunities of native West Virginia trees and a picnic area for gathering and relaxing. The second program element was a sensory garden with walking paths through fragrant native plants and a small space for wine tastings, culinary demonstrations and intimate weddings. The butterfly garden included programming a walking path through native West Virginia flora with seating areas. Each of these programs, though not necessarily with the identical name, have been included and expanded upon in the master plan. Through the following description of each space, the illustration of the stakeholders' wish list is shown with detailed explanation of vegetation and user function. One of the economic-driving stakeholders, The Stonewall State Park Foundation, promotes a list of goals shown below: 
1. Ensure the viability and future development of Stonewall Resort State Park

2. Create a sustainable legacy for future generations

3. Education, recreation and preservation

4. Immerse in the outdoor beauty in a wide variety of ways

5. Encourage healthy lifestyles (“Stonewall state park,”)

These goals, too, have been addressed and included as a part of the master plan which will also be shown throughout the following specific space descriptions. The Foundation's sustainability initiative demonstrates the stakeholder's values that will be shown in the development of the design (Echols, 2008).

Figure 37. Site Master Plan

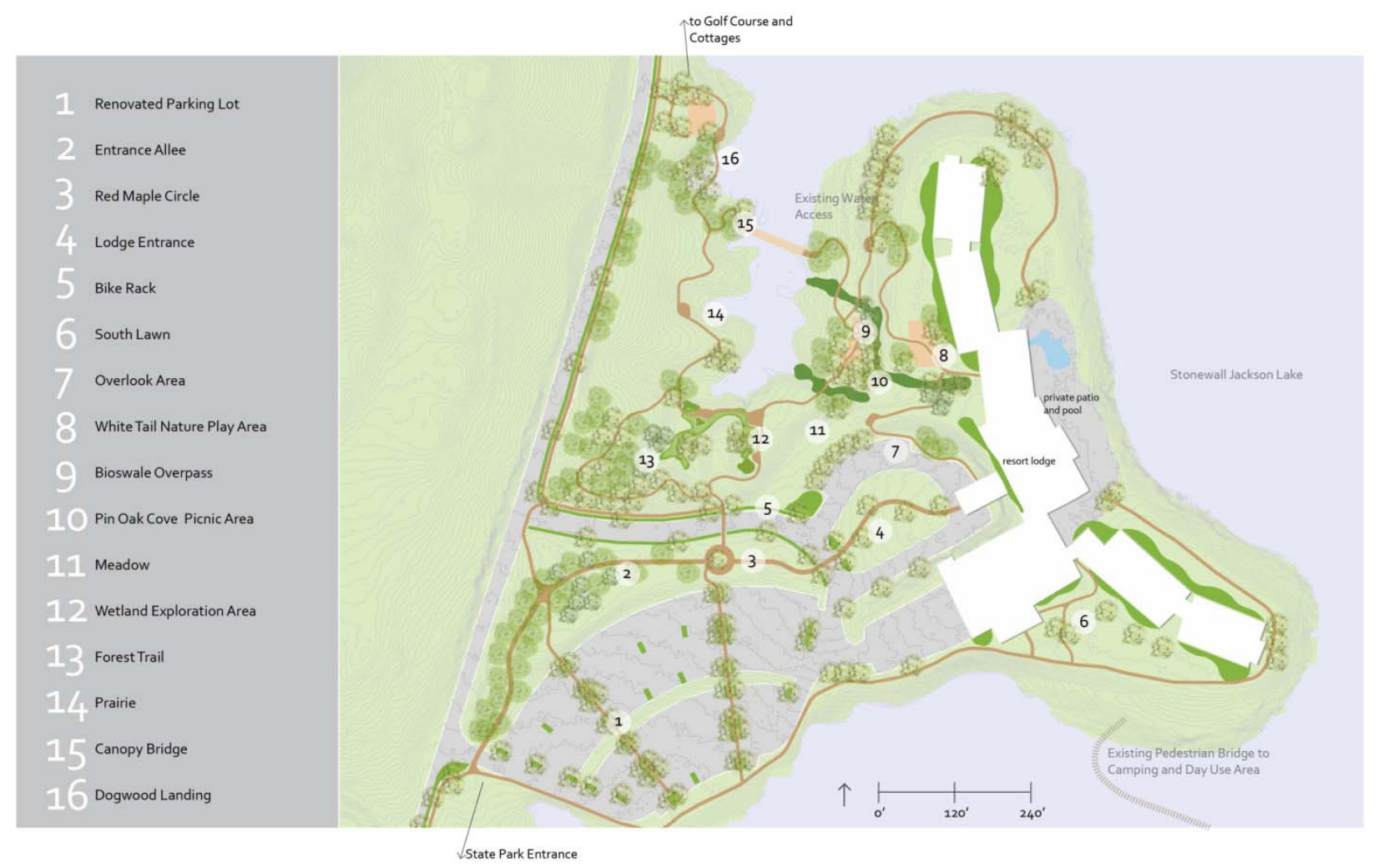

Each space of the design will be discussed as though a visitor is walking through the space, for physical continuation through the site. A reference map is included for each 
perspective and section rendering to locate the image on the master plan. To begin, pedestrians and bikers traveling from the entry drive now have the opportunity to go through a secluded entrance allee towards the lodge and park area (Fig. 38, 39). To the west, the allee will be lined with native hardwood trees enclosing the space before opening to a no-mow turf lawn for views of the adjacent park and lake. This path provides a safe entrance for pedestrians separate from automobile traffic (Fig. 40). For people entering the site by car, they too are provided with a safe enclosed walkway to the entrance allee (Fig. 41,42). The parking lot will be punctured with two arteries of pedestrian paths lined with bioretention cells. These paths bring focus to the pedestrians and lodge visitors carrying luggage while slowing down automobile traffic through the parking lot (Fig. 43). Betula papyrifera, Quercus palustris and Viburnum trilobum are added to the stormwater seedmix in the bioretention cells to provide an overhead canopy and to create visual awareness for drivers.

Figure 38. Entrance Allee

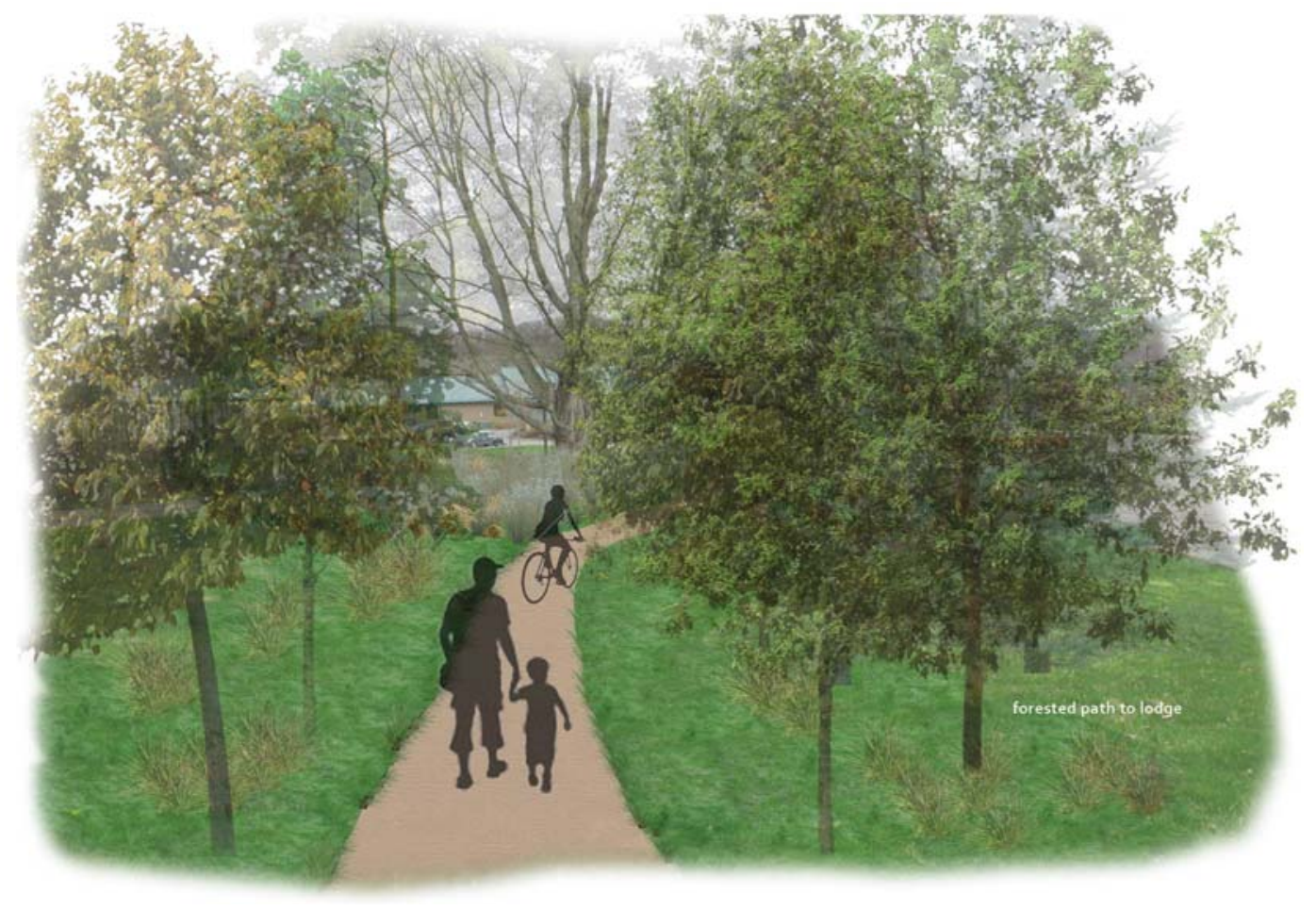


Figure 39. Reference to Figures 38, 40

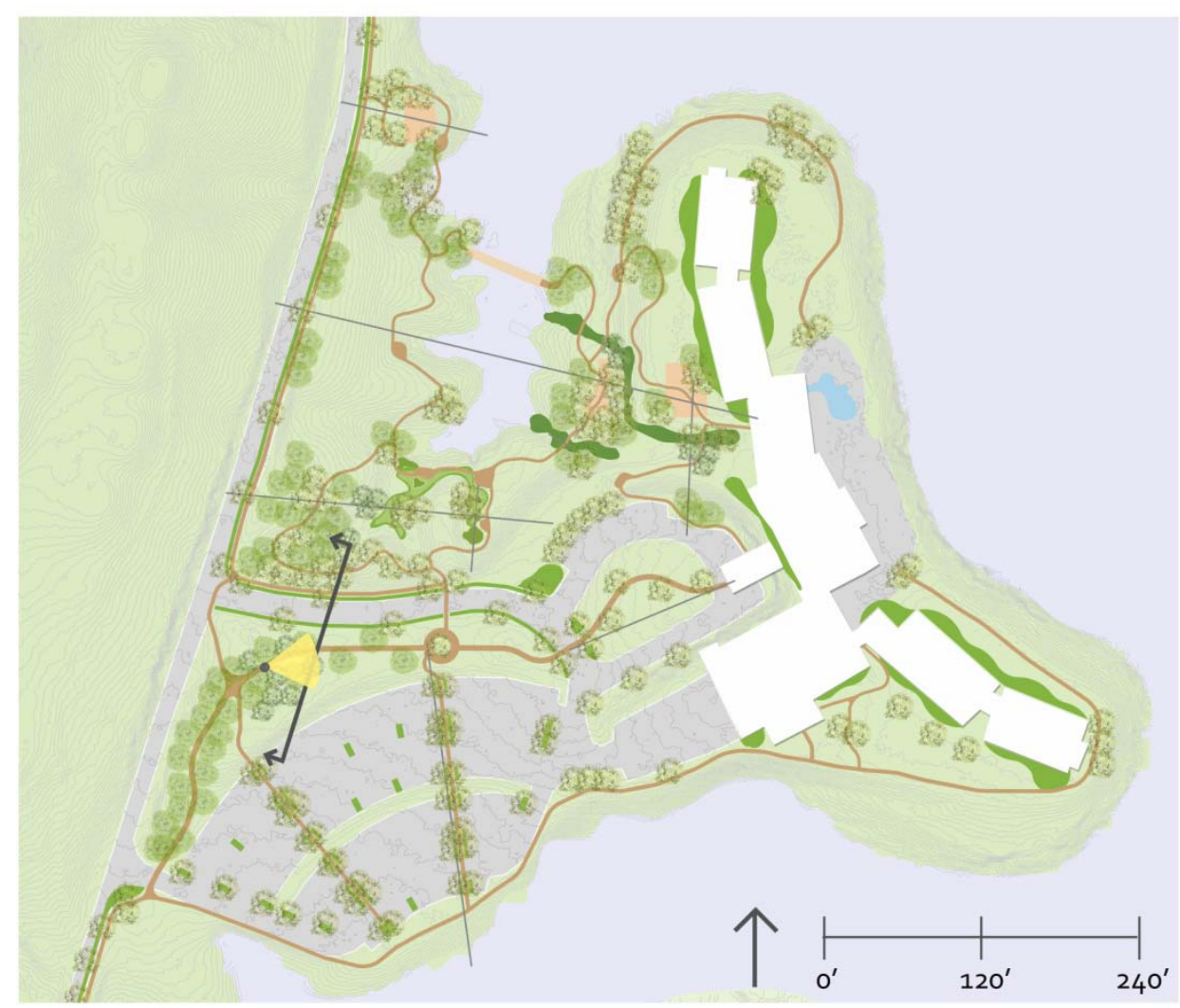

Figure 40. Entrance Allee Cross-Section

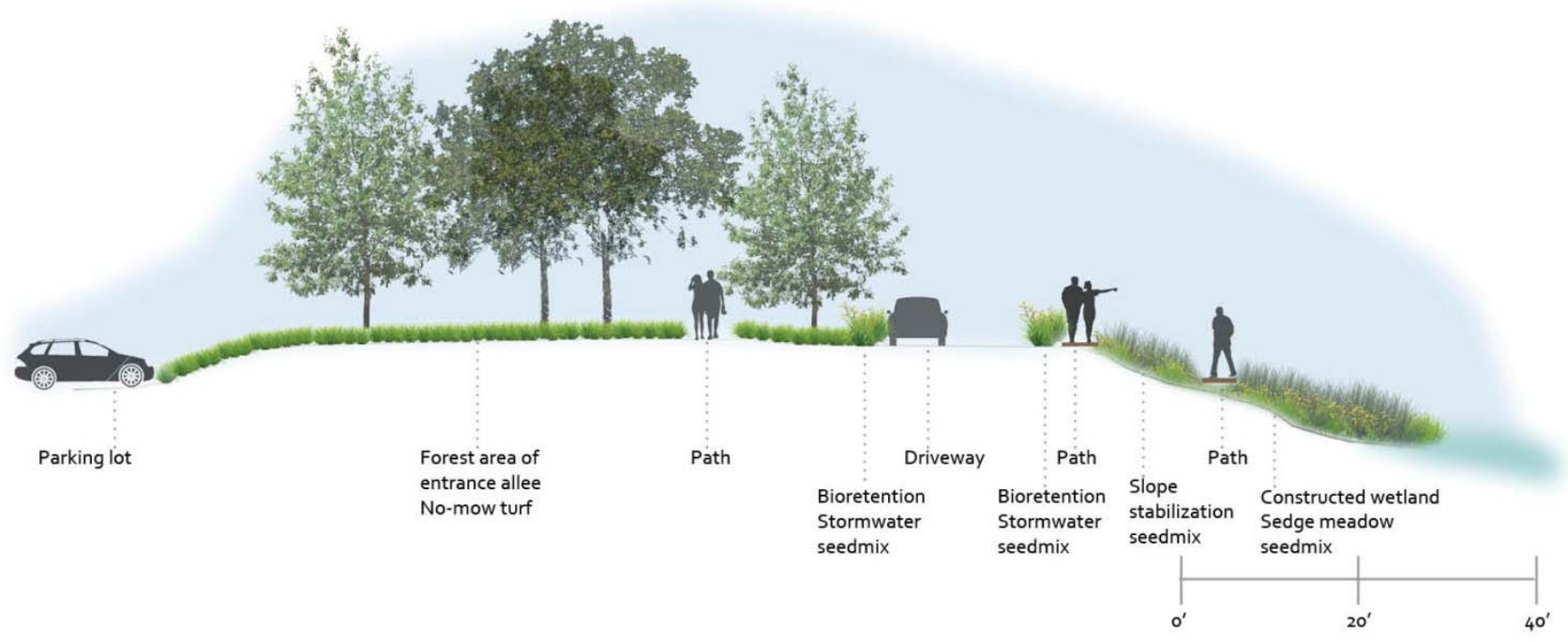


Figure 41. Parking Lot Artery

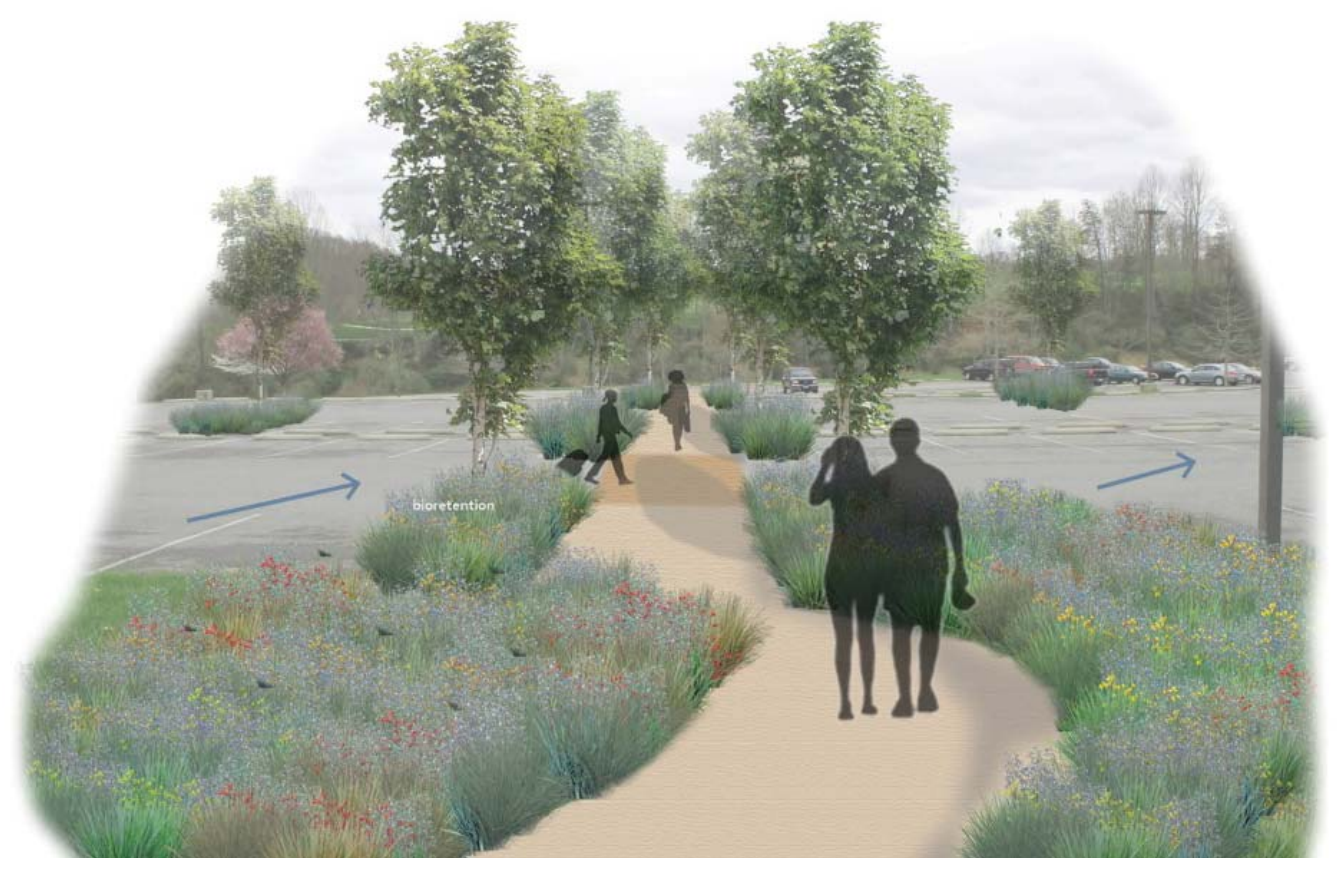

Figure 42. Reference to Figures 41, 43

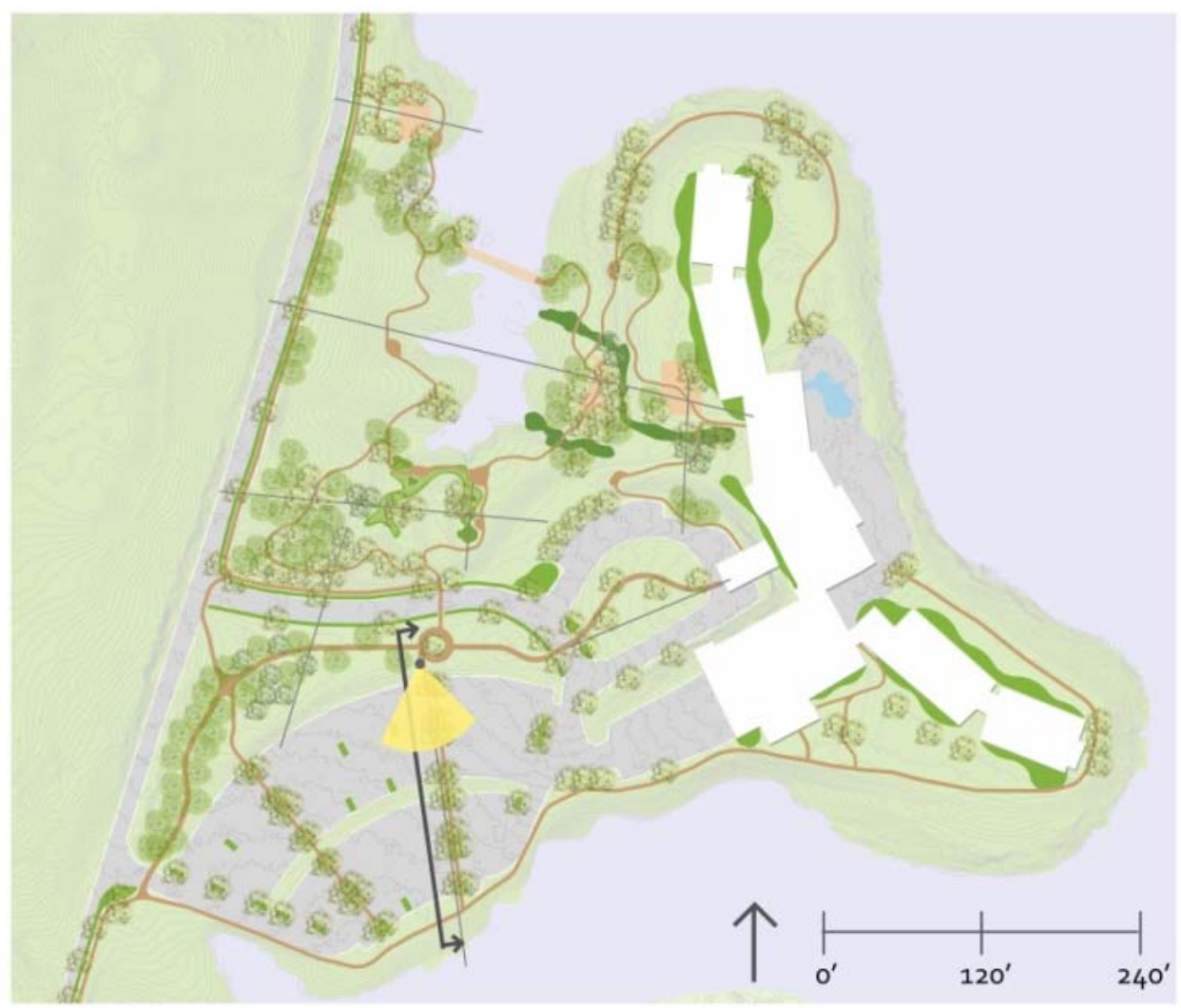


Figure 43. Parking Lot Cross-Section

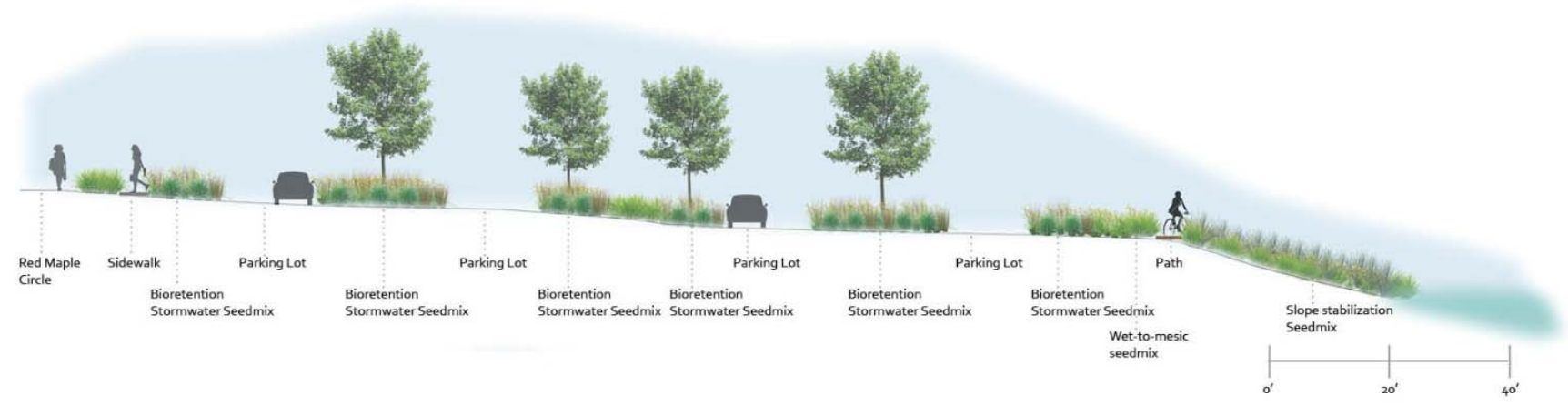

The parking lot arteries and entrance allee intersect at Red Maple Circle. This round-about is the meeting point for four paths, creating a gathering space for visitors (Fig. 44, 45). The Acer rubrum (Red Maple) serves as a focal point and is framed with a stone seating wall for guests to meet or take a rest. Surrounding the paths, low profile prairie seed mix is designed to provide ample seasonal color for a vibrant entrance. The stormwater seed mix of the bioretention cells along the road will blend into the low profile prairie species. From Red Maple Circle, guests entering the site can cross to the wetland adventure area or to the lodge entrance path. All directions are shown on a rustic sign with wooden arrows pointing in the direction of each space. 
Figure 44. Red Maple Circle

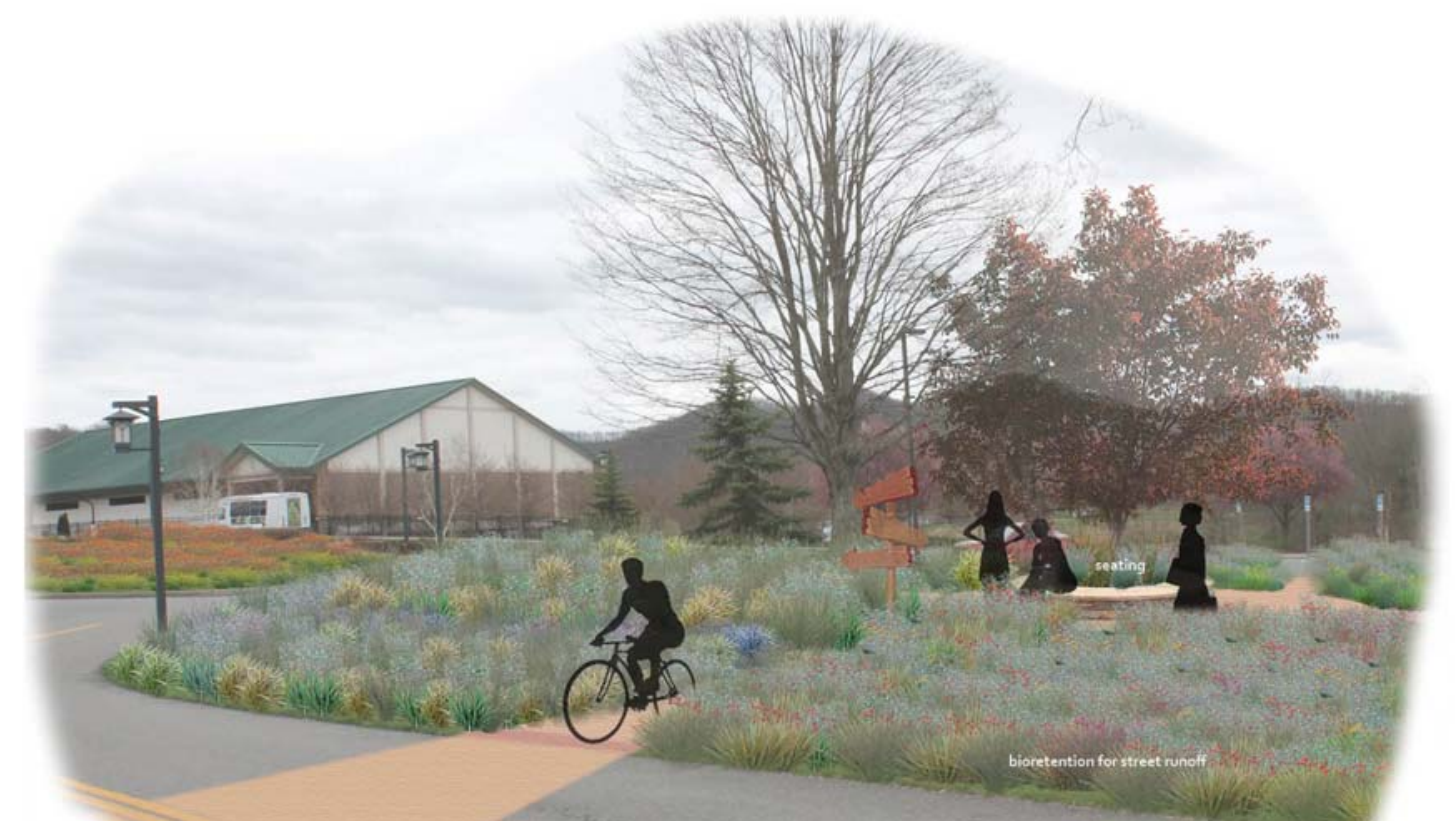

Figure 45. Reference to Figure 44

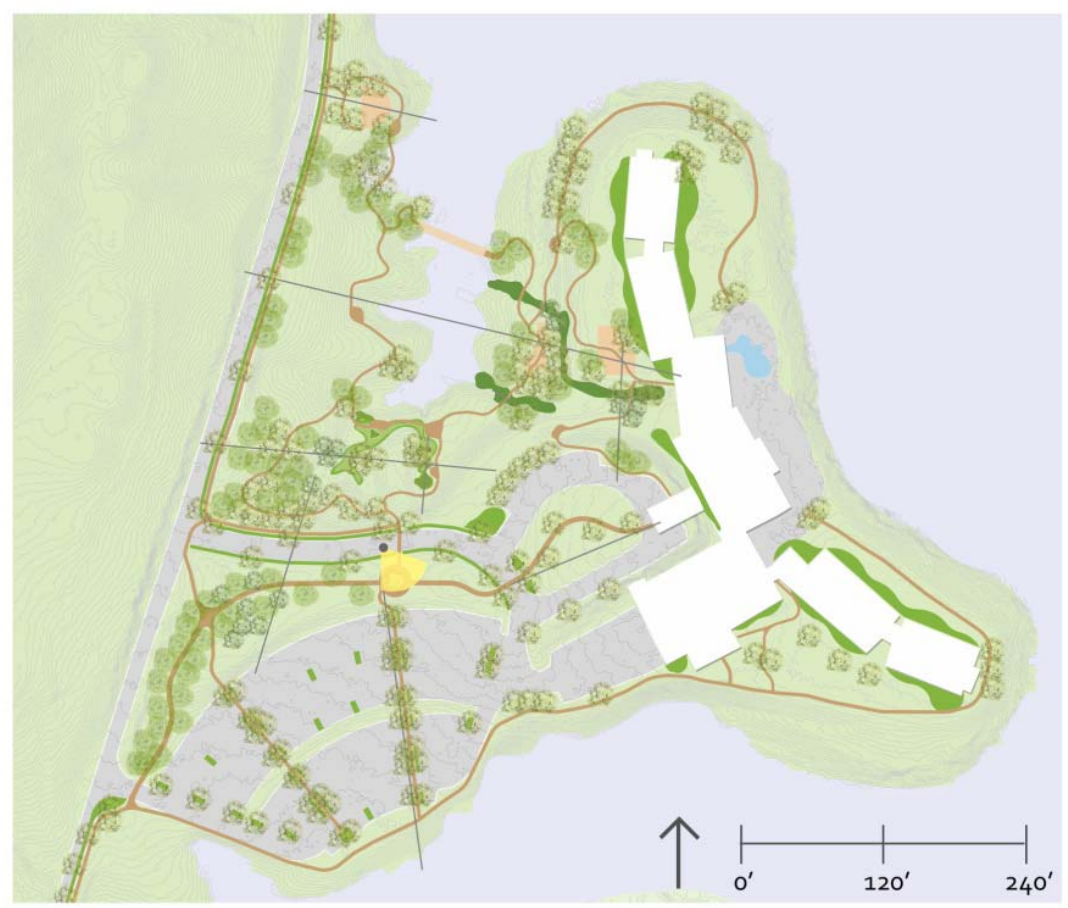

Walking from Red Maple Circle, guests and visitors of the lodge continue along a new entrance path into the lodge (Fig. 46, 47). The large green island in front of the lodge entrance is 
currently underutilized, and pedestrians now walk alongside the cars into the lodge. The proposed path cuts through the green island, and is surrounded by low-profile prairie species (Fig. 48). Visitors enter the lodge and view the property from a new perspective. Signature palette species proposed in the vegetated lodge entrance include Schizachyrium scoparium, Liatris spicata, Spiraea alba, and Cornus florida. Adirondack chairs are clustered at each end of the path, repeating the existing chairs under the porch entrance. These seating areas invite guests to wait on friends before exploring the adjacent park, meet friends before heading to the golf course, or wait as their car arrives to load luggage. Once under the porch entrance, existing gutter pipes will be disconnected and rain chains will be installed (Fig. 49). These stormwater management details provide not only infiltration for the bioretention cells, but also aesthetic appeal in both rain or shine conditions. Several enhancements are proposed around the edge of the lodge, which will now be discussed before shifting to the fully designed park and cove area west of the lodge.

Figure 46. Lodge Entrance

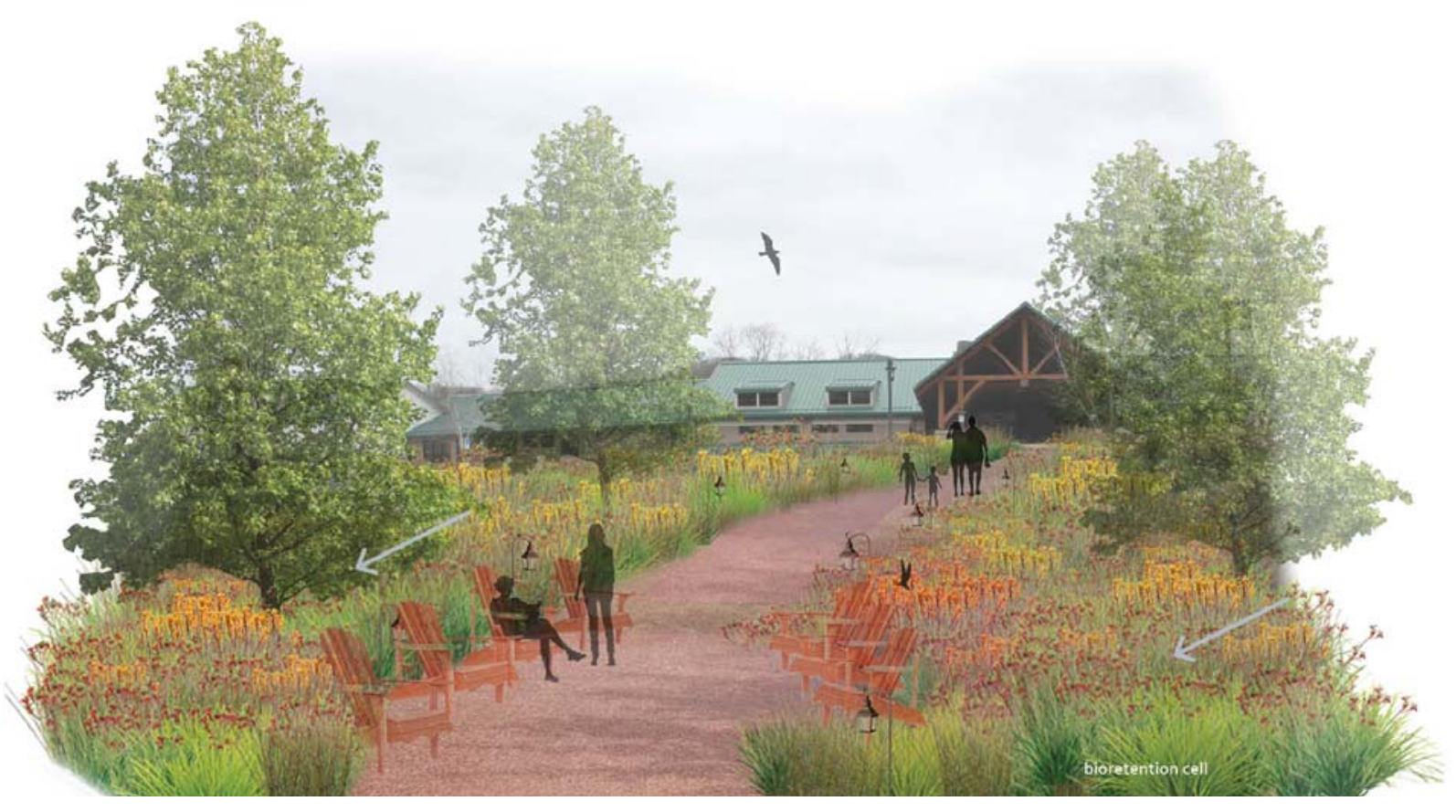


Figure 47. Reference to Figures 46, 48

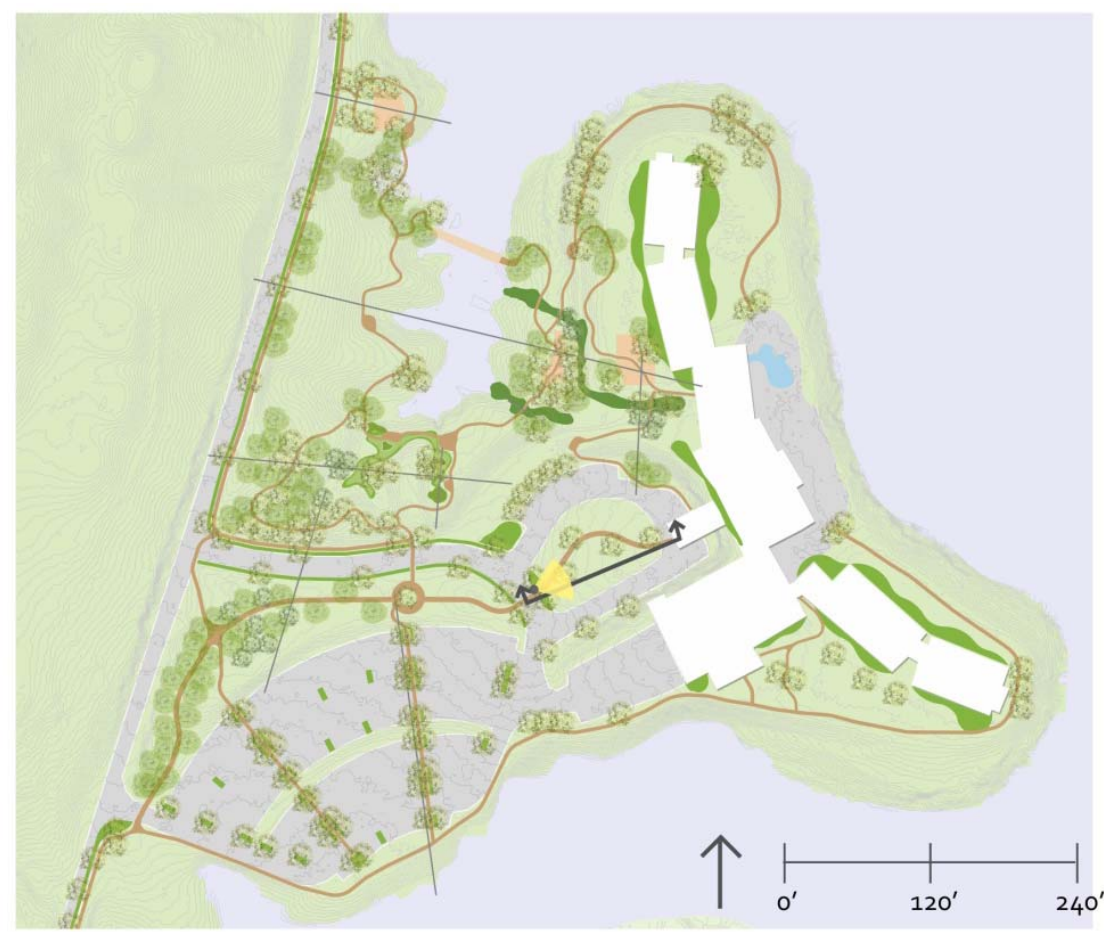

Figure 48. Lodge Entrance Cross-Section

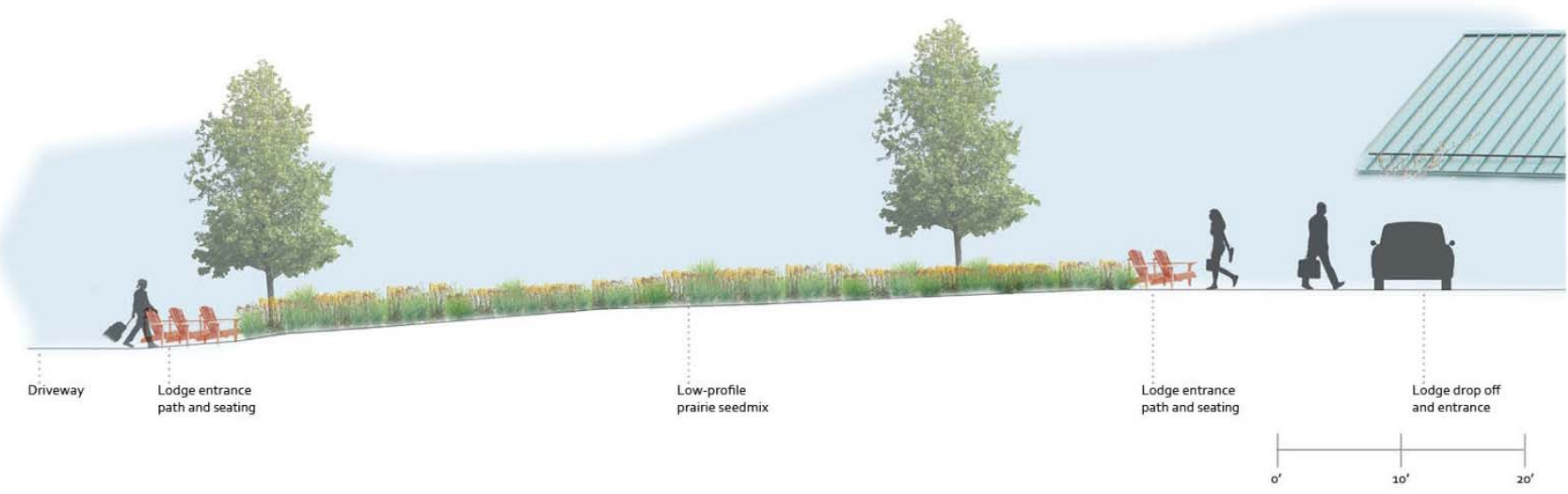




\section{Figure 49. Rain Chain Detail}

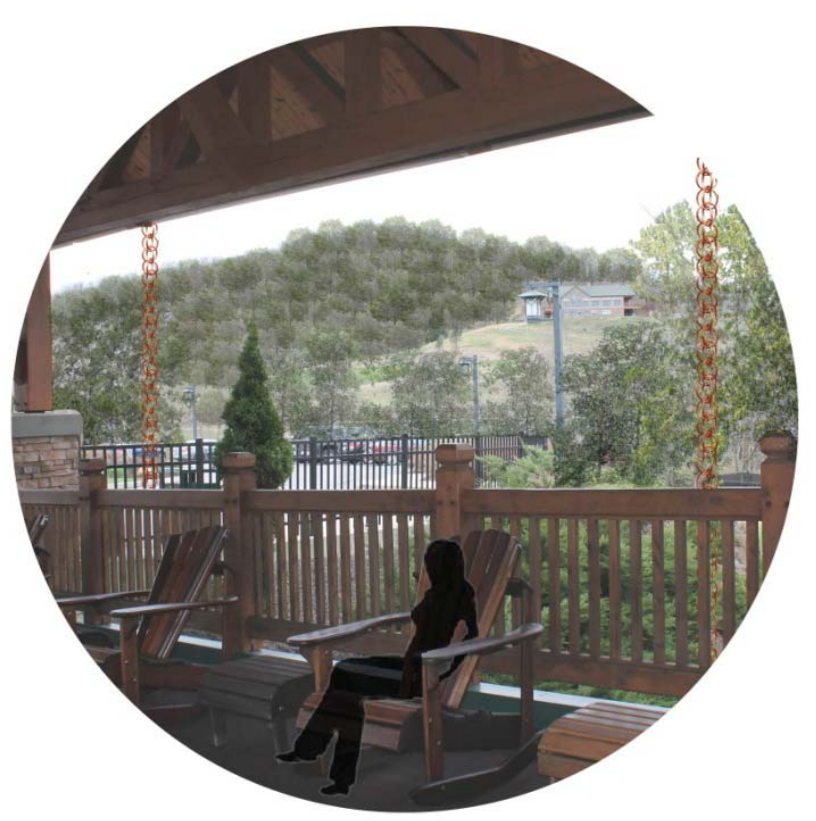

An open lawn outside the lodge’s conference center currently functions as an open event space often used for weddings, receptions, and tent events. The proposed South Lawn creates a defined vegetated path with an overhead pergola extending from the side entrance, becoming the perfect setting for wedding events (Fig. 50, 51). This path leads pedestrians in and out of the lodge, framed with bioretention cells and sedge meadow seed mix. Acer rubrum and Cornus florida are scattered in the lawn to provide shade for events and balance to the large building. No-mow turf planted on the majority of the lawn maintains the versatility for the multi-use outdoor space. Bioretention cells provide a vegetated foundation to the buildings, while collecting stormwater runoff from the buildings as gutter pipes will be detached (Fig. 52). Ilex verticillata and Spiraea alba, from the signature palette, will be included within the stormwater and sedge meadow seed mixes to provide volume, multi-season interest, and architectural structure. The added vegetation and space definition enhance this space whether an event is taking place or not. 
Figure 50. South Lawn

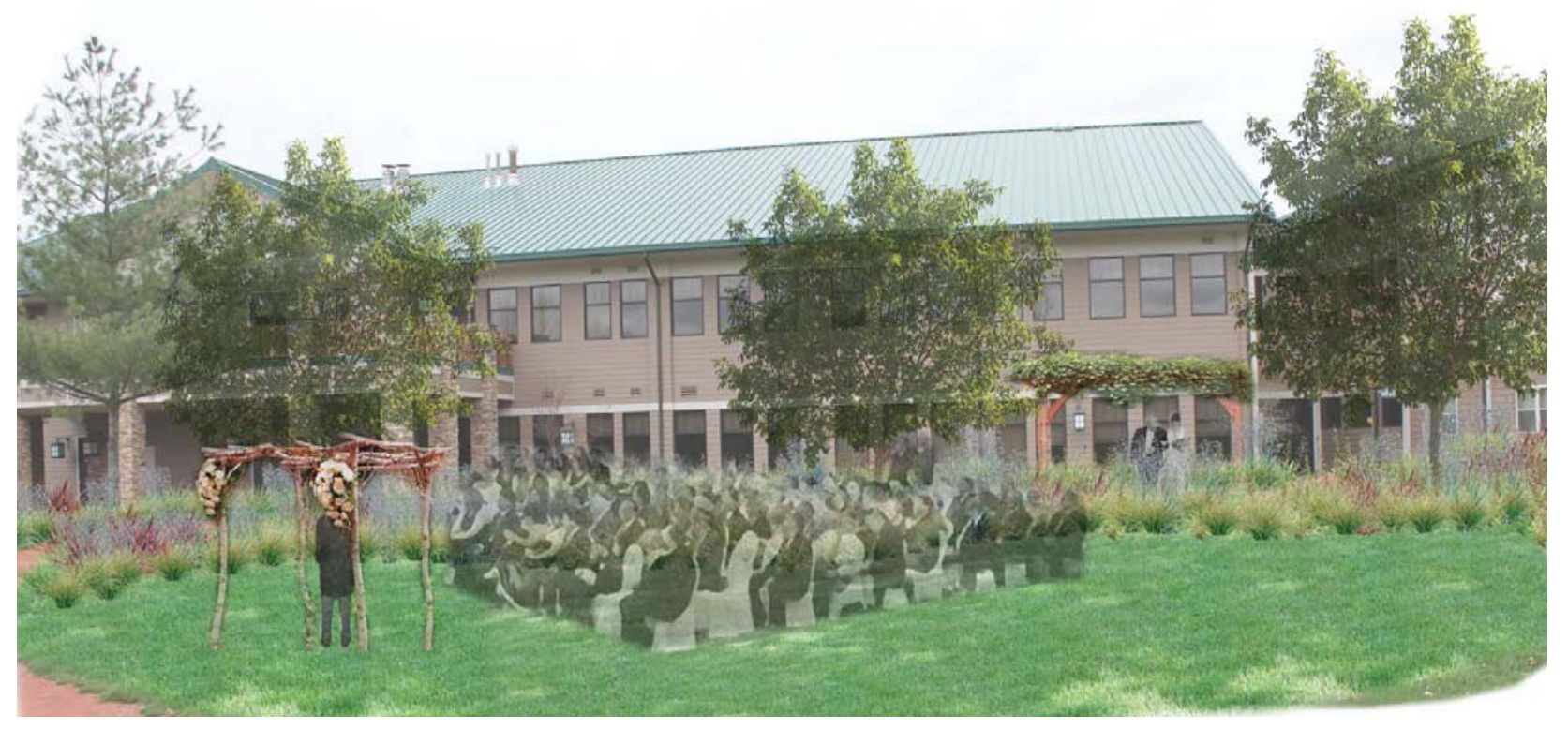

Figure 51. Reference to Figure 50

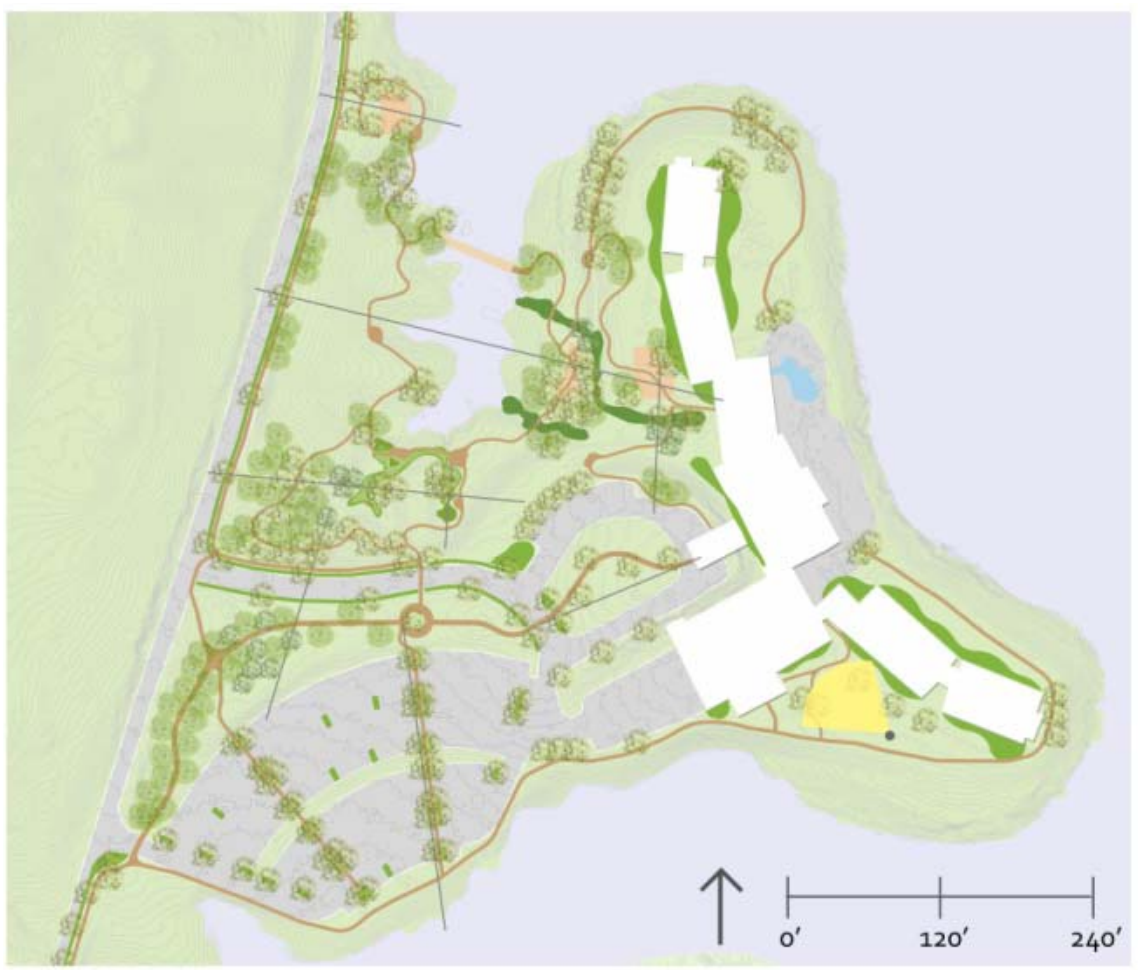


Figure 52. Detached Downspout Detail

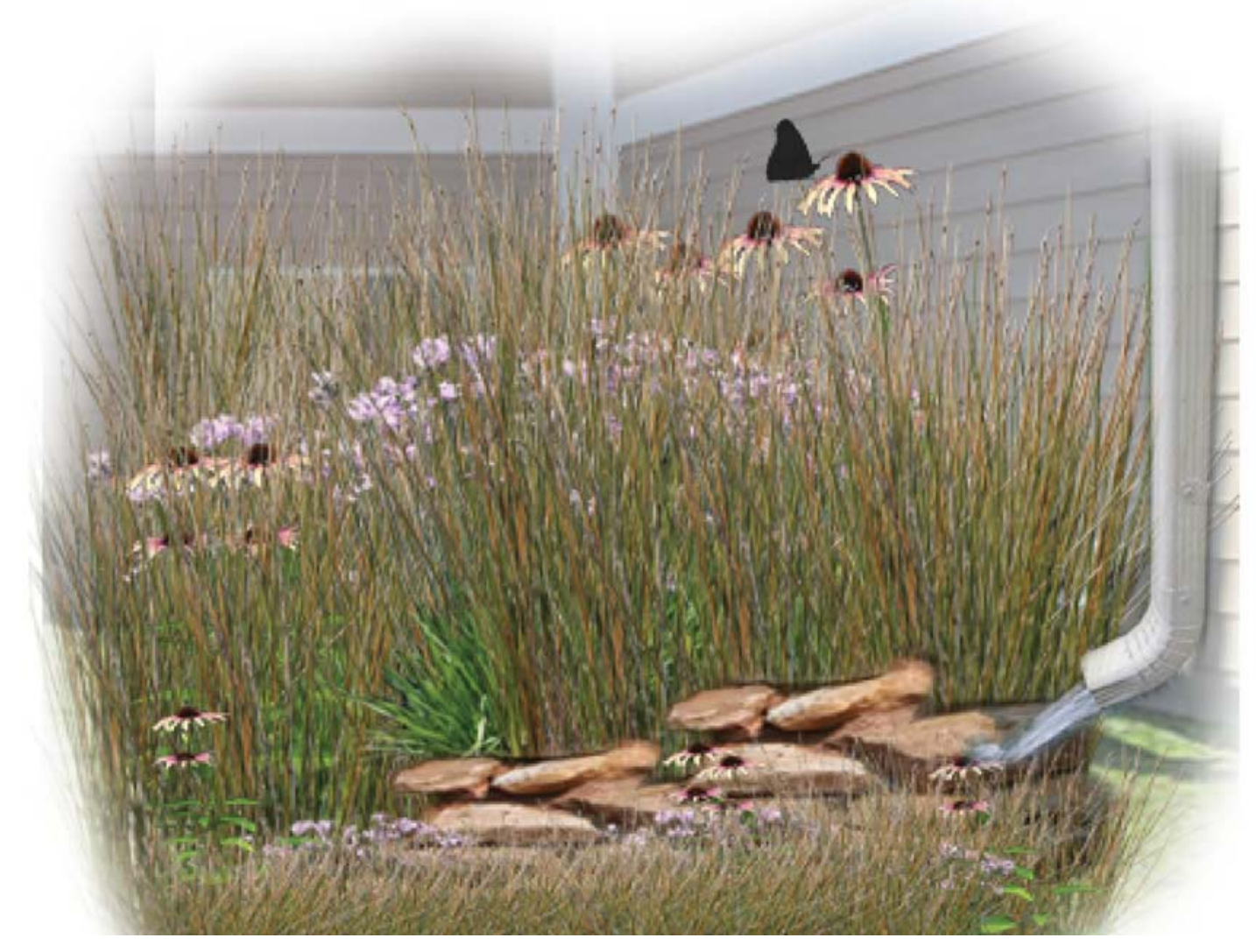

Continuing around the back of the lodge, proposed bioretention cells will soften the buildings edge while also bringing stormwater runoff into the adjacent soils (Fig. 53, 54). The path along the northern part of the peninsula suffers from a sedimentation and erosion problem as identified in the hydrology analysis (Fig. 54, 55). The slope stabilization seed mix will establish deep roots to prevent erosion and increase infiltration. Additional signature palette species along the paths include Schizachyrium scoparium, Calamagrostis canadensis, Liatris spicata and Ratibida pinnata. These grasses and forbs not only provide stormwater management but also create aesthetic appeal to enhance the entire path on the lodge peninsula. 
Figure 53. Rear Lodge Path

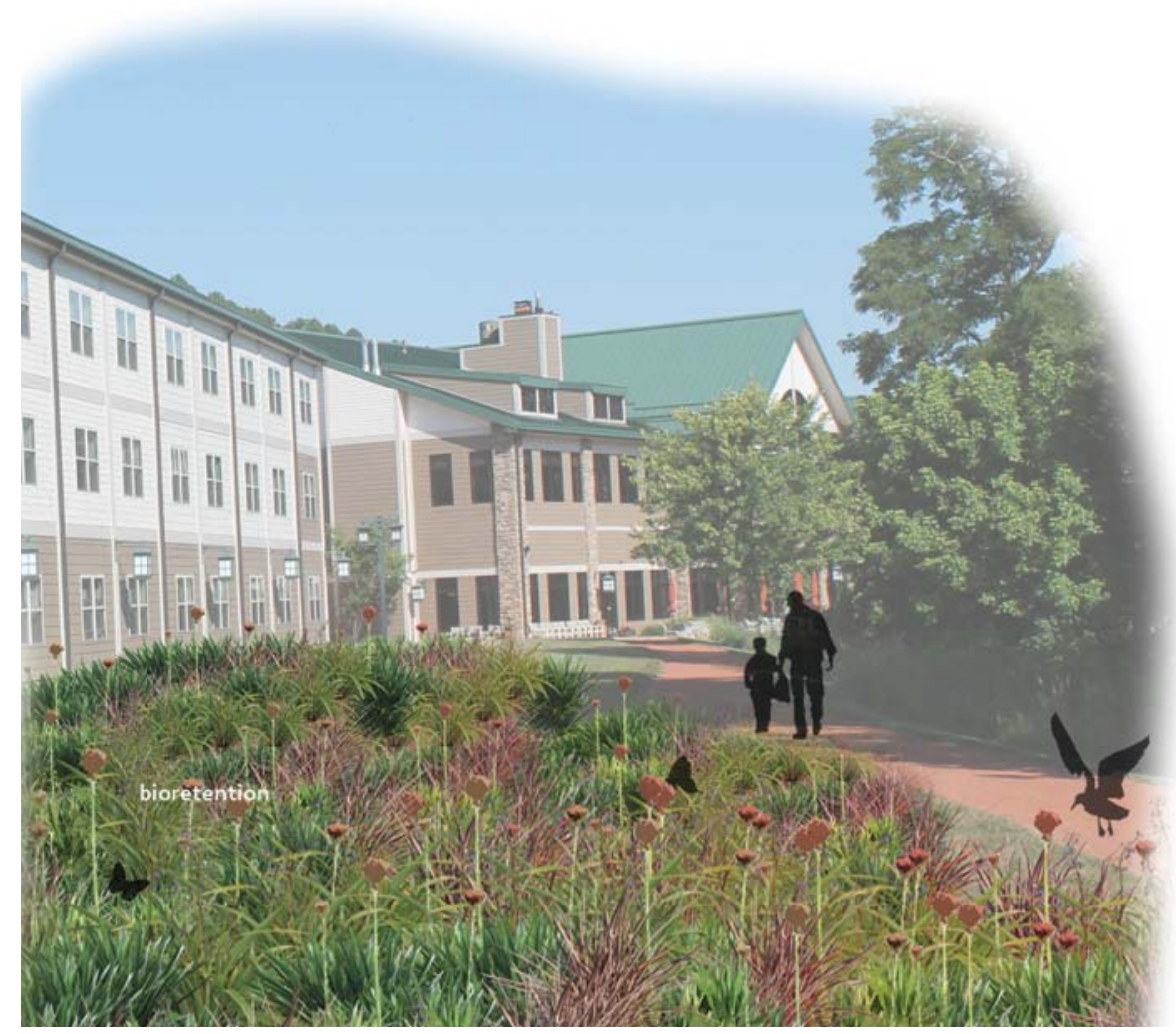

Figure 54. Reference to Figures 53, 55

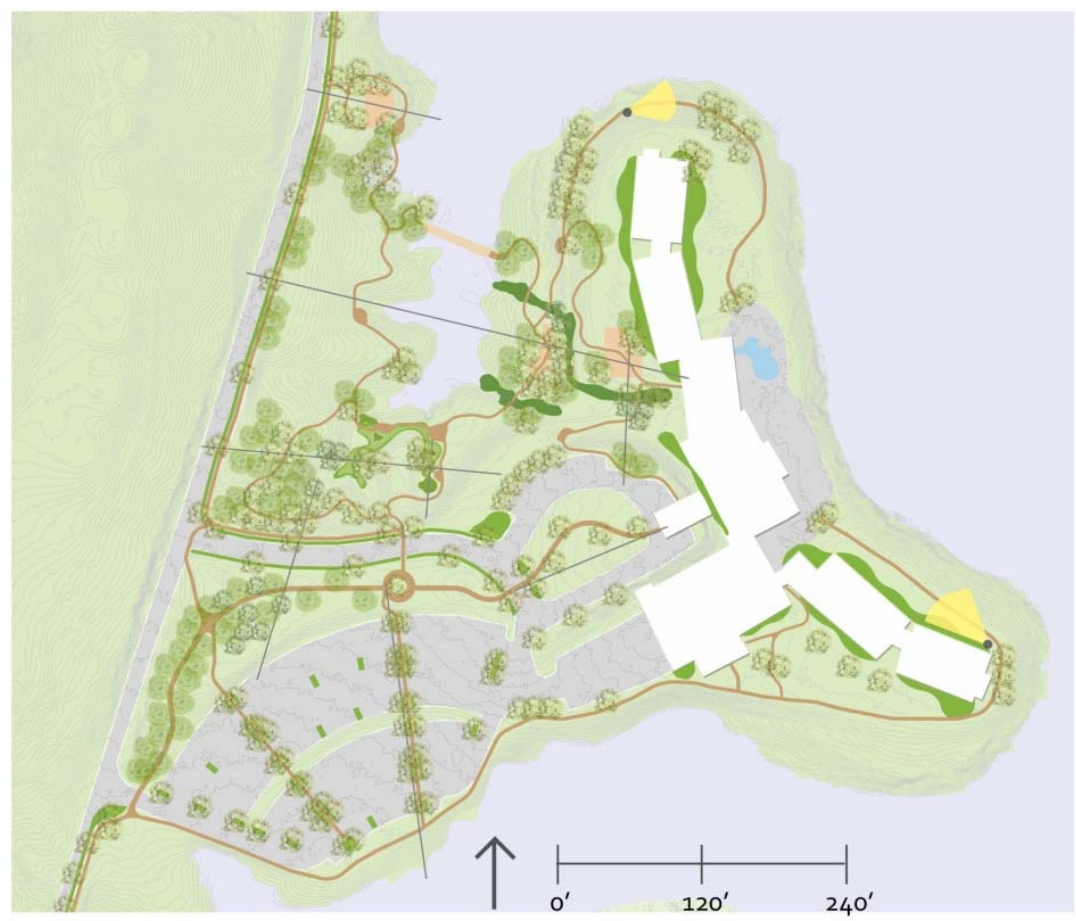


Figure 55. Northern Lodge Path

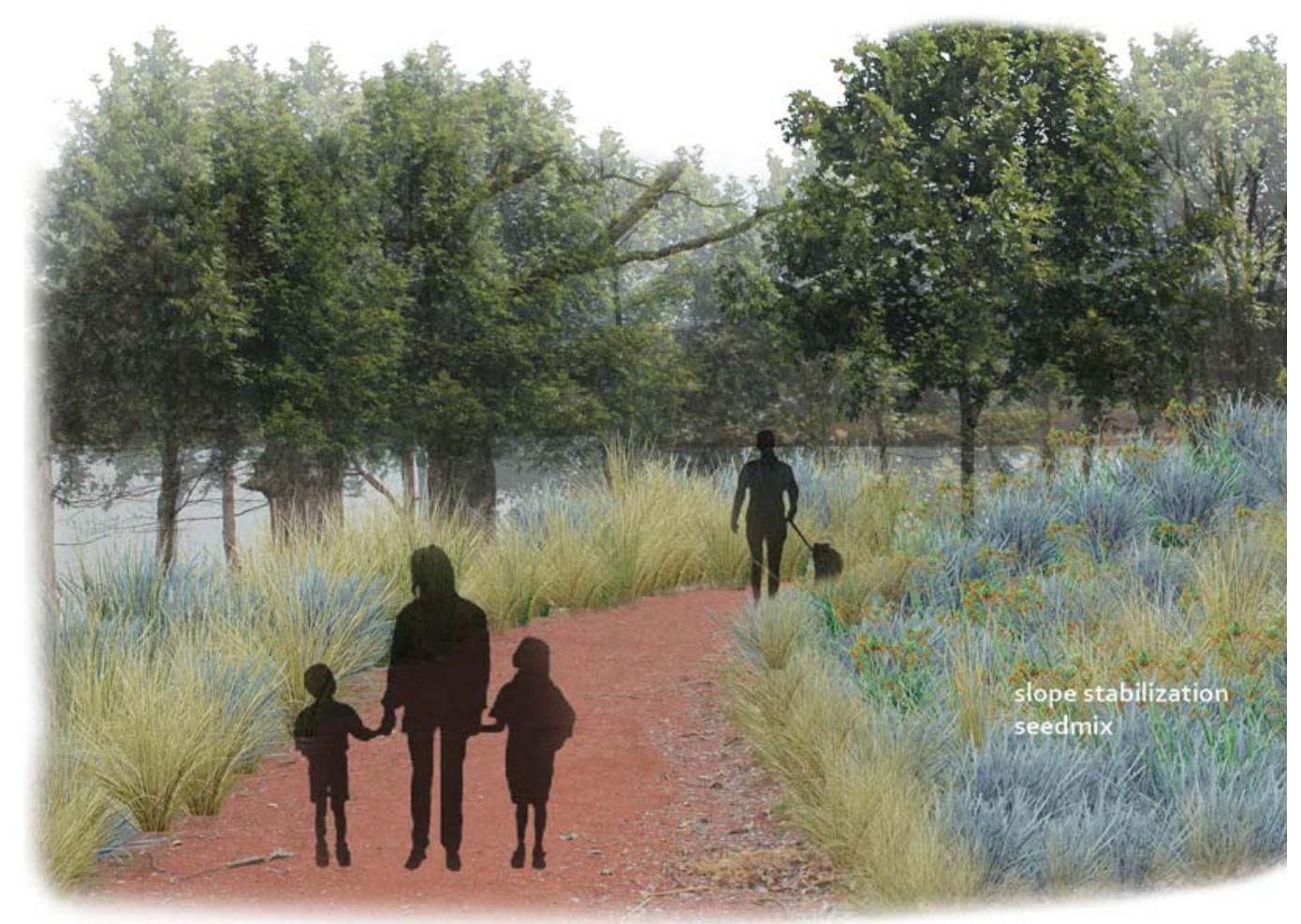

Shifting from the lodge perimeter path, the rest of the design description will explain and illustrate the undeveloped cove area beginning with a proposed elevated path from the lodge entrance. The steep topography creates a challenge for visitors to walk from the lodge entrance to the adjacent cove area to access the lake. The proposed path allows visitors to easily access the various spaces around the cove from the lodge, which provides an overlook of the space giving people a glimpse of the upcoming experiences (Fig. 56, 57). As the path reaches the flat area near the existing play ground, it crosses over the bioswale bringing people into the stormwater management (Fig. 58). Boulders will be found throughout the spaces, providing educational information of stormwater management, vegetation, habitats and soils. These interpretive signs are low to the ground as the eye will be low looking at the specific design 
element. Here at the bioswale crossover, a boulder will provide information to elaborate upon the visual stormwater design.

Figure 56. Site Overlook

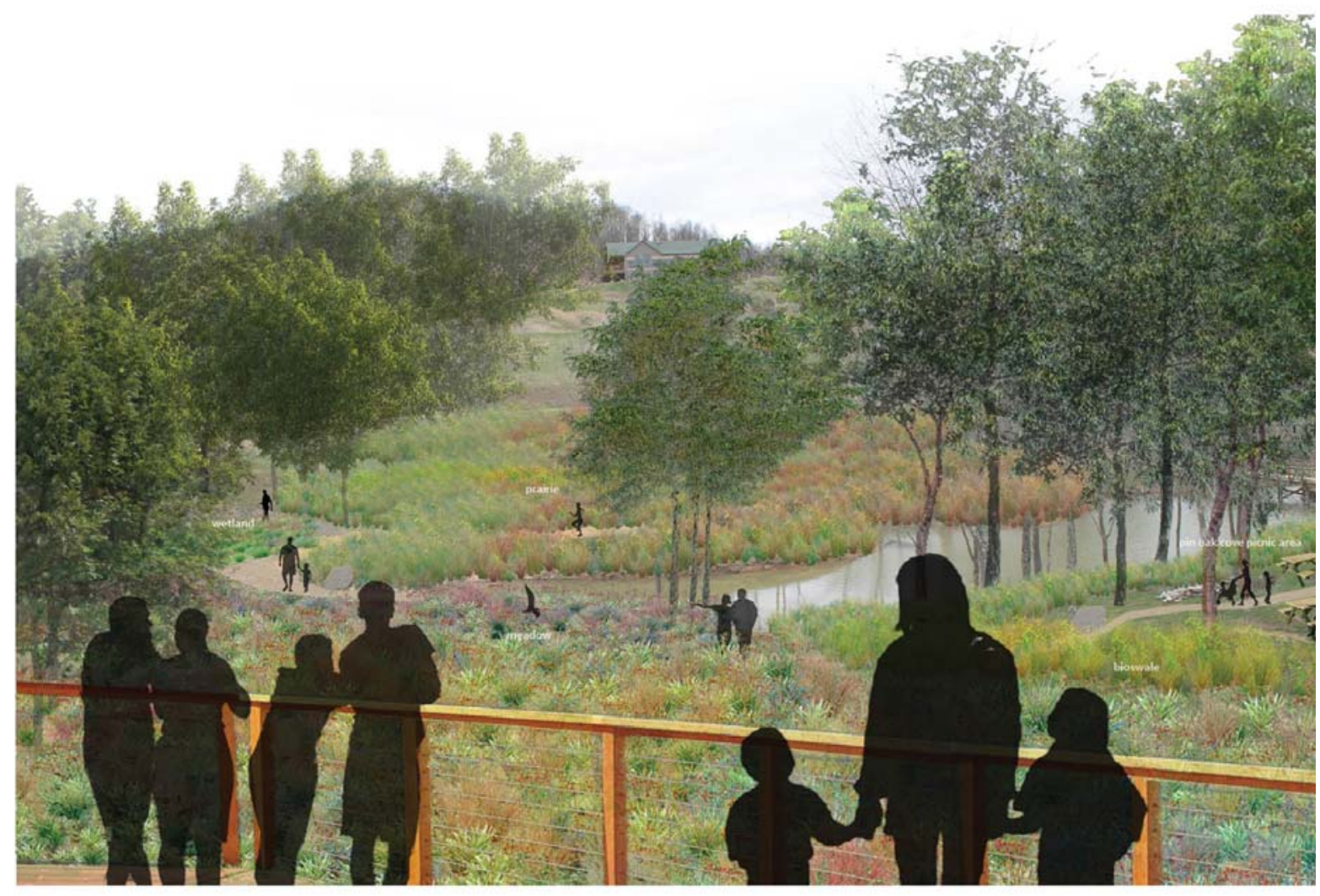

Figure 57. Reference to Figures 56

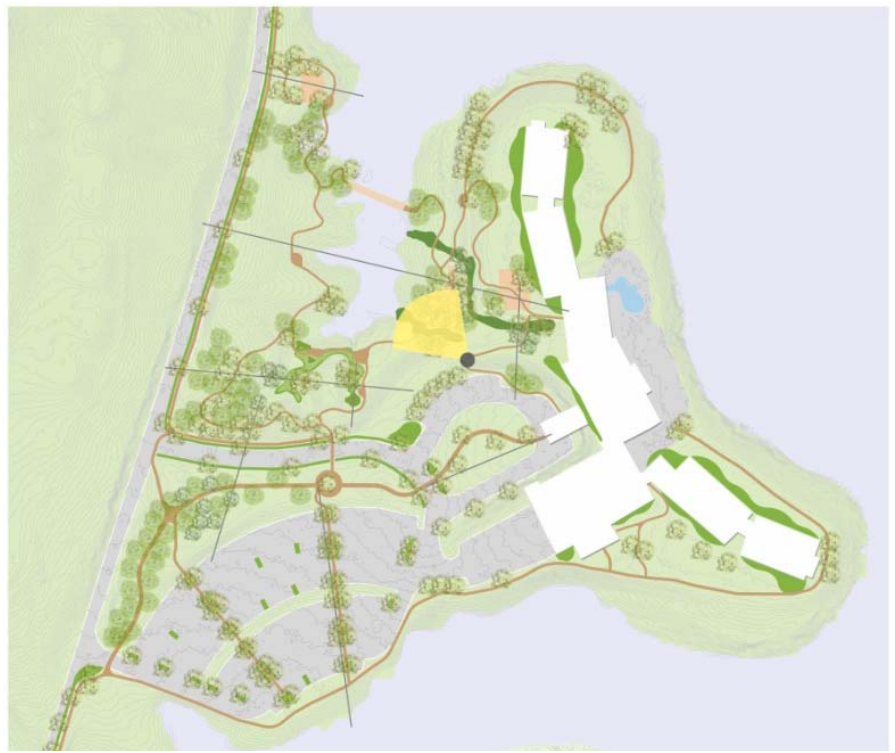


Figure 58. White Tail Nature Play Area Cross-Section

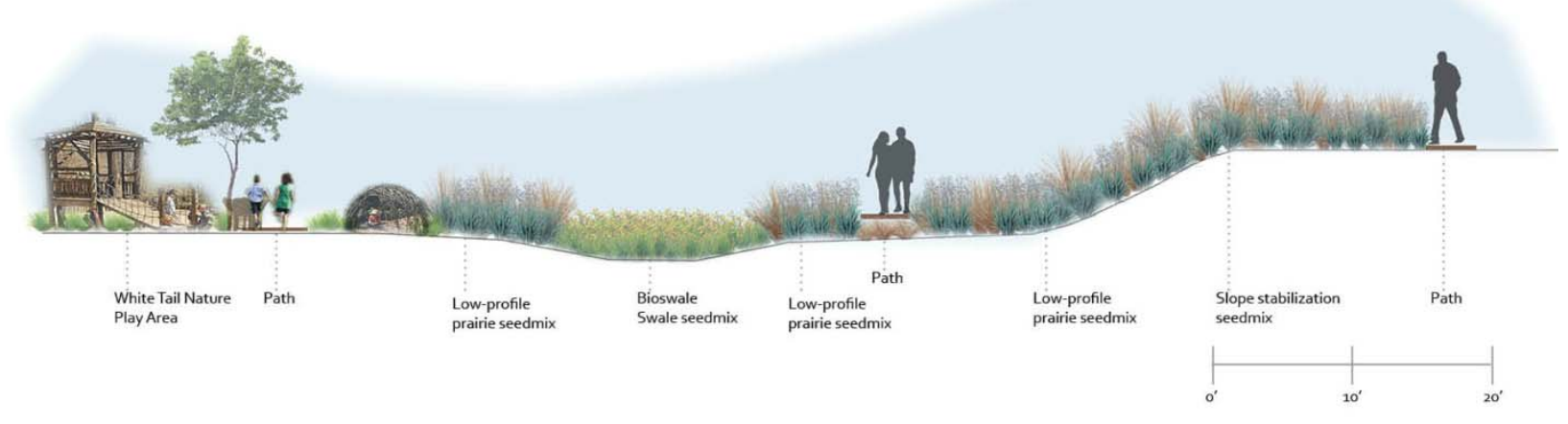

Once over the bioswale, visitors begin entering the White Tail Nature Play Area (Fig. 59, 60). As discussed in the analysis section, the existing playground confines children and shields them from interaction with nature. The proposed White Tail Nature Play Area brings the playground away from the building and into the natural landscape. A variety of naturalistic playground pieces are dispersed for exploration and adventure. The path guides visitors through the play area as a way to provide visibility of the play area and interaction with the children. The play area is densely surrounded by low profile prairie seed mix to create an edge. The bioretention cells along the building's edge will intermix with the low profile prairie creating a fluid vegetated wave. Quercus palustris are planted around the play area to provide shade and structure. Additional signature palette plants include Aster puniceaus, Ratibida spicata and Viburnum tribolum. 
Figure 59. White Tail Nature Play Area

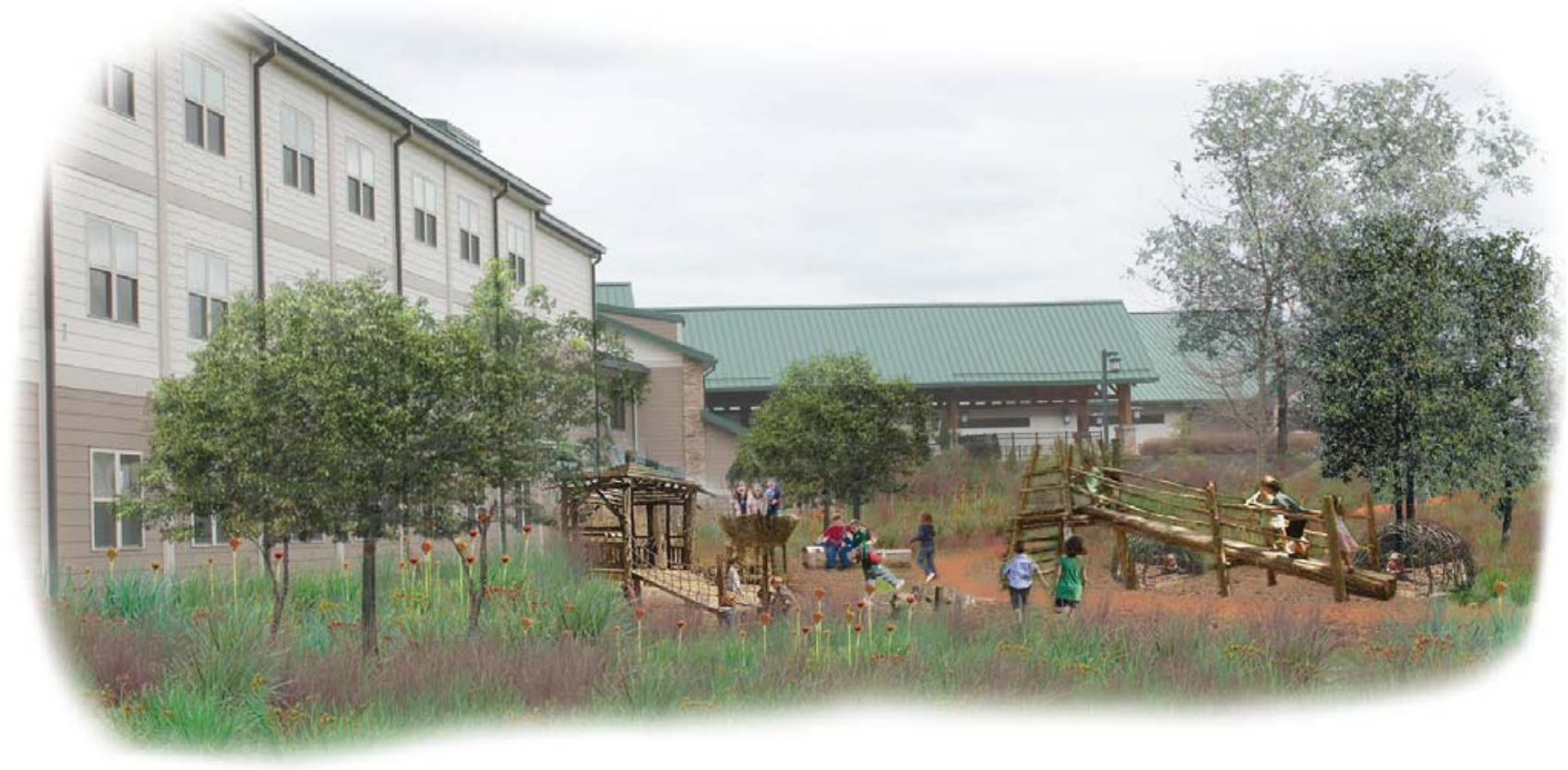

Figure 60. Reference to Figures 58, 59

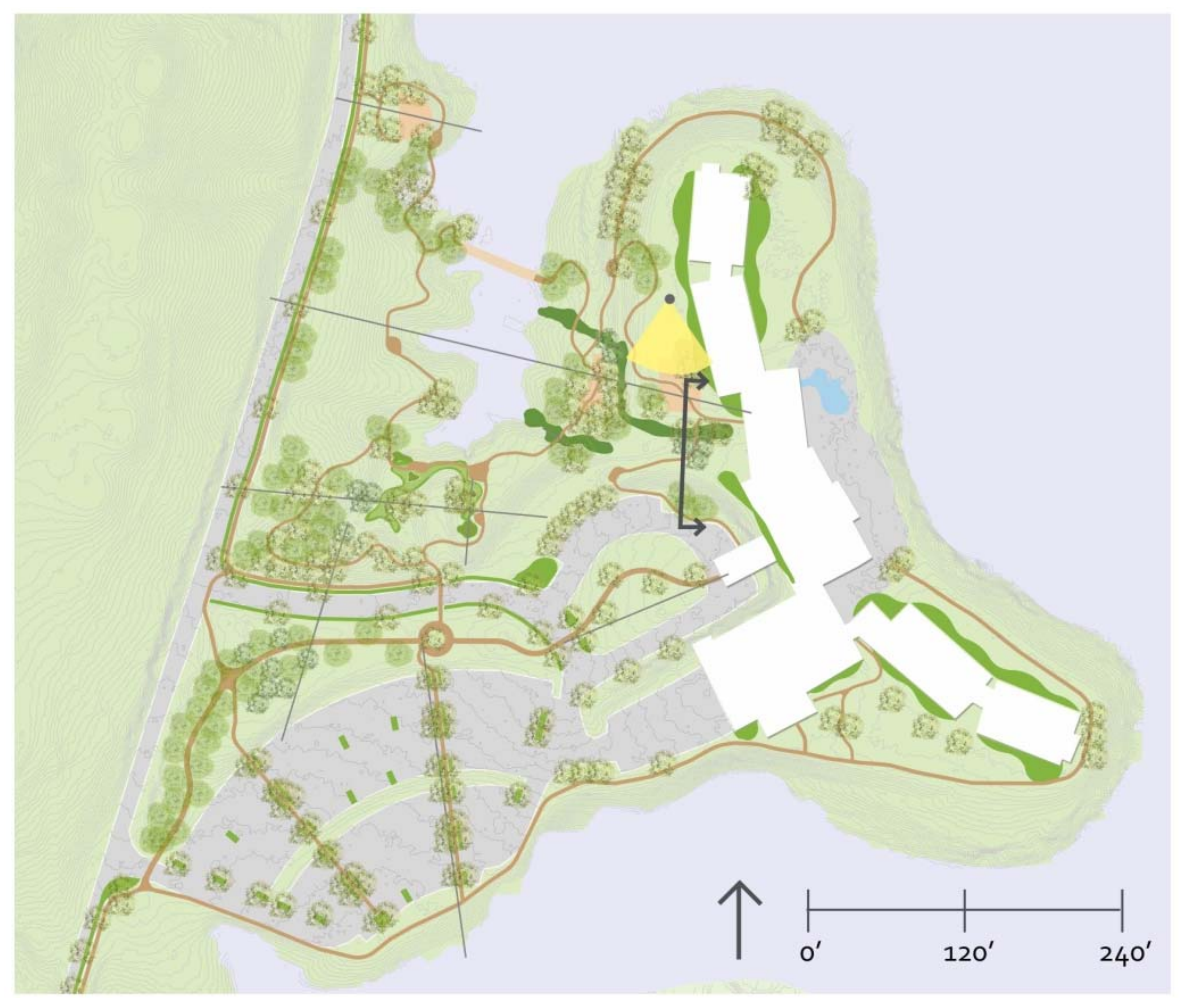


After walking through the White Tail Nature Play Area, visitors work their way down the grade, crossing over the same bioswale as previously passed before entering the Pin Oak Cove Picnic Area (Fig. 61, 62). An existing vegetated area currently offers a few picnic tables. This area becomes very saturated in rain events; therefore, the adjacent bioswales are designed to collect the runoff and prevent the picnic area from being too wet. On each side of the path, seating is provided for guests, visitors and summer day camps. Children from the White Tail Nature Play Area can also easily access the picnic area for a snack break. The area will be planted with Quercus palustris and Acer rubrum to enhance the overhead canopy providing a shaded area for eating and socializing. Swale seed mix is used in the bioswales and sedge meadow seed mix blends into the rest of the Pin Oak Cove Picnic Area. Calamagrostis canadensis and Viburnum tribolum will stabilize the soils on the steep slopes and create rhythm along the path. After walking through the picnic area, a second bioswale is crossed, highlighting the stone cascades (Fig. 63). The oak trees will then disperse, opening to a broad meadow.

Figure 61. Pin Oak Cove Picnic Area

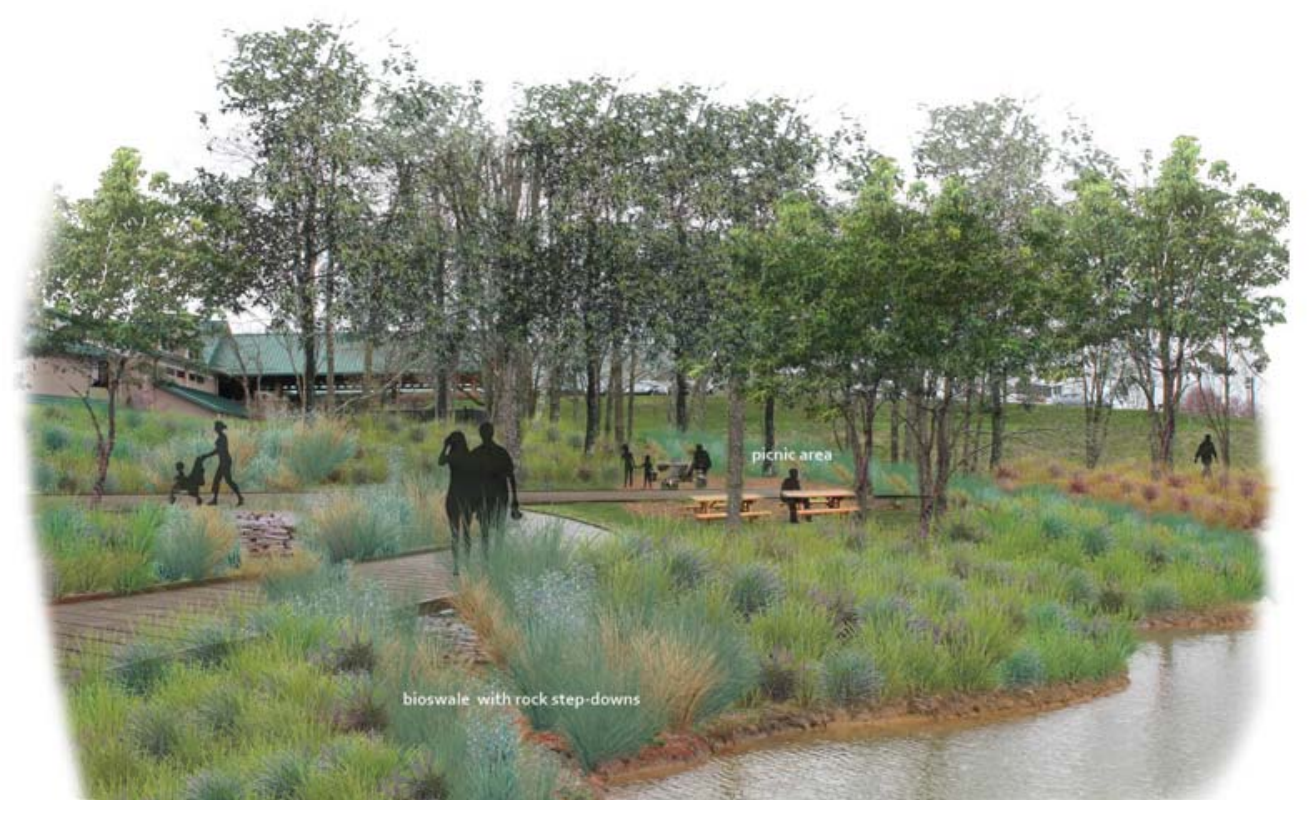


Figure 62. Reference to Figures 61

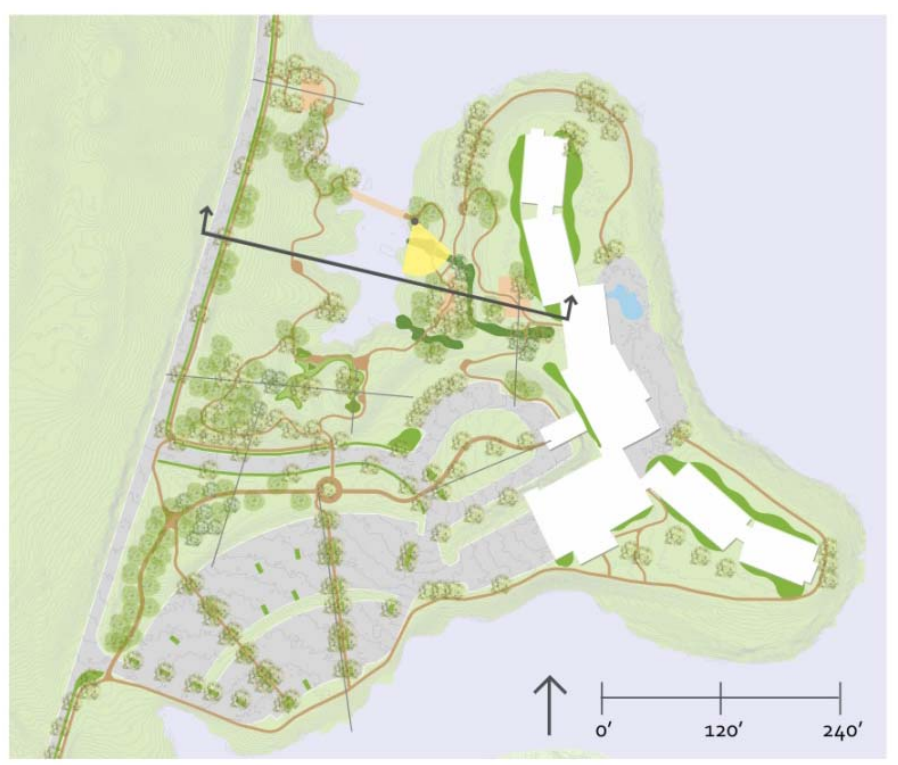

Figure 63. Bioswale Cross-Section

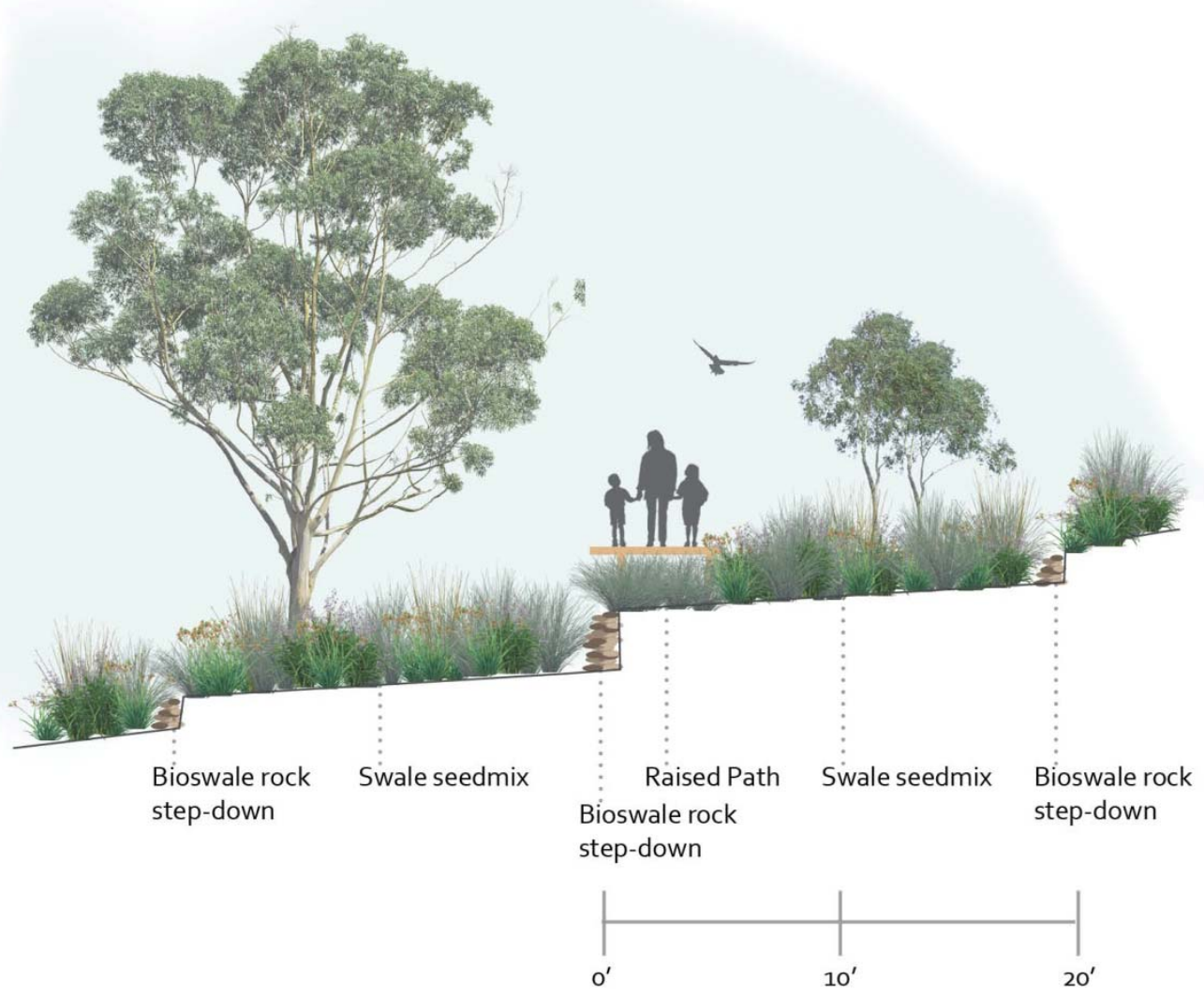


The meadow serves as a passageway into the wetland providing extended views of the forest and lake (Figures 64, 65). Small groupings of oak trees link to the adjacent Pin Oak Cove, although the meadow predominately consists of three different seed mixes: slope stabilization, sedge meadow and low profile prairie. The seed mixes provide a large variety of species creating a diverse habitat (Shaw and Schmidt, 2003). Along the meadow path, interpretive stone signs will provide information on the various vegetation groups and their specific functions in the ecosystem. The meadow flows directly into the edge of the constructed wetland.

Figure 64. Meadow

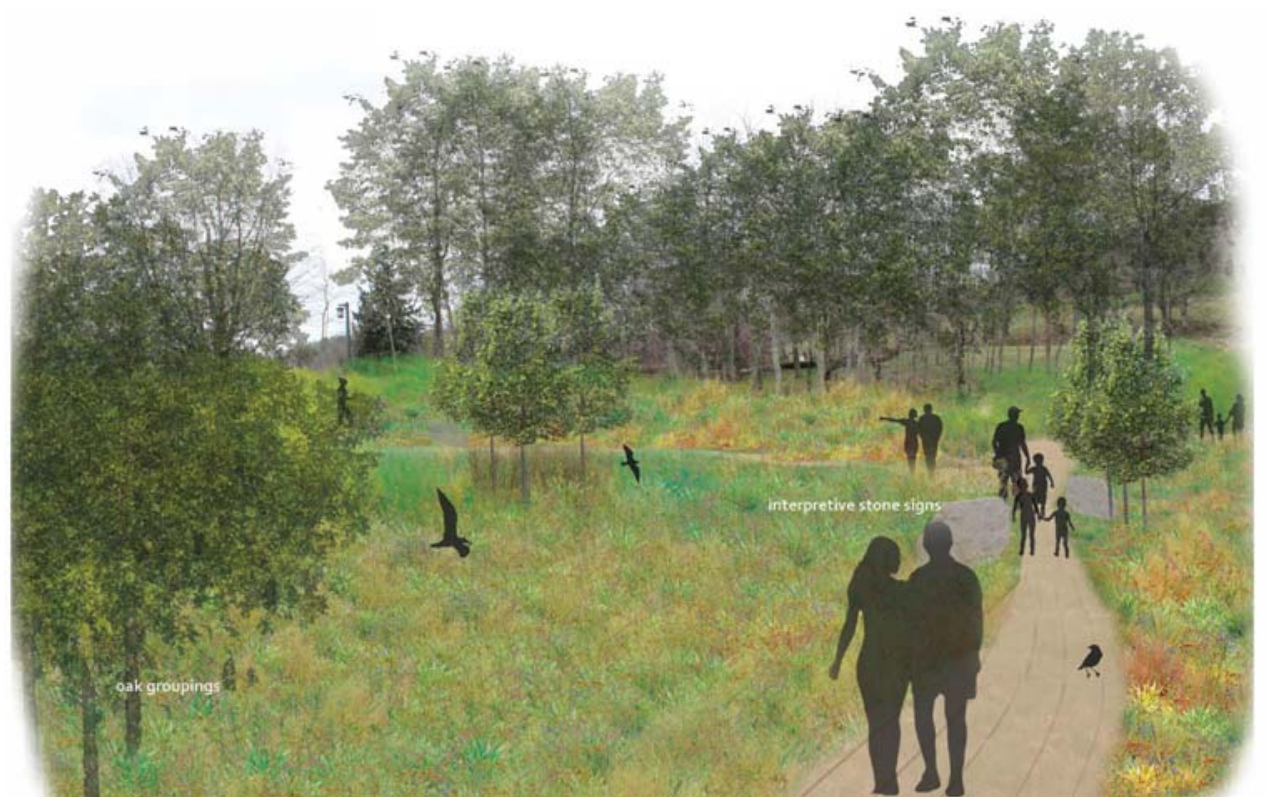

Figure 65. Reference to Figure 64

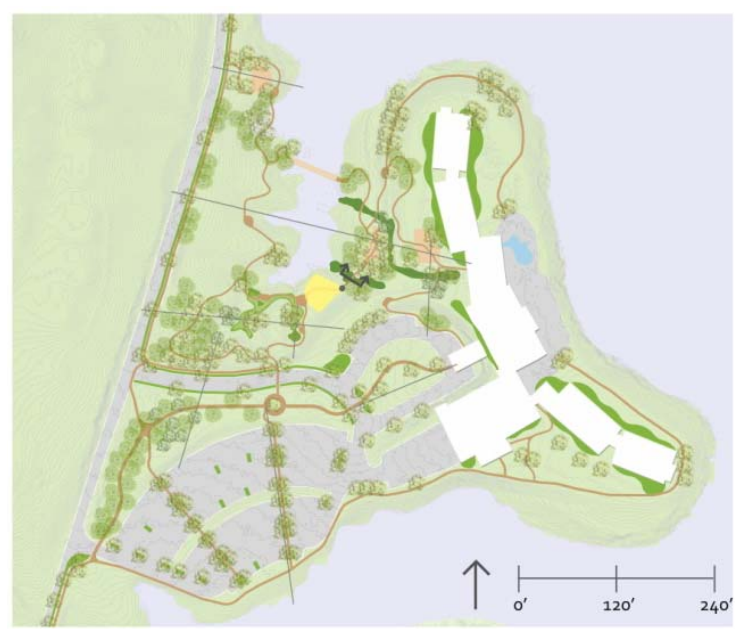


The Wetland Exploration Area can be accessed from the meadow path or from the path connected to the Red Maple Circle (Fig. 66, 67). As discussed in the stormwater management section, the constructed wetland has different elements which filter, infiltrate and convey water (“Constructed wetlands”, 2011). Each element will be explained on the interpretive stones guiding visitors through the phases of water cleansing in the wetland (Fig. 68). A low platform extends from the path providing an area for educational demonstrations and gatherings. Similar to the meadow, the Wetland Exploration Area offers a variety of vegetation with three different seed mixes: stormwater, emergent wetland and wetland edge. These seed mixes will thrive in the wet conditions, enhancing the function of the wetland. Visitors will see the transition of species across the landscape, while also being provided with the written explanation on the signs. The elevated walkways bring people into the wetland, rather than walking around it, giving them an opportunity to touch, smell, hear and see the working wetland.

Figure 66. Wetland Exploration Area

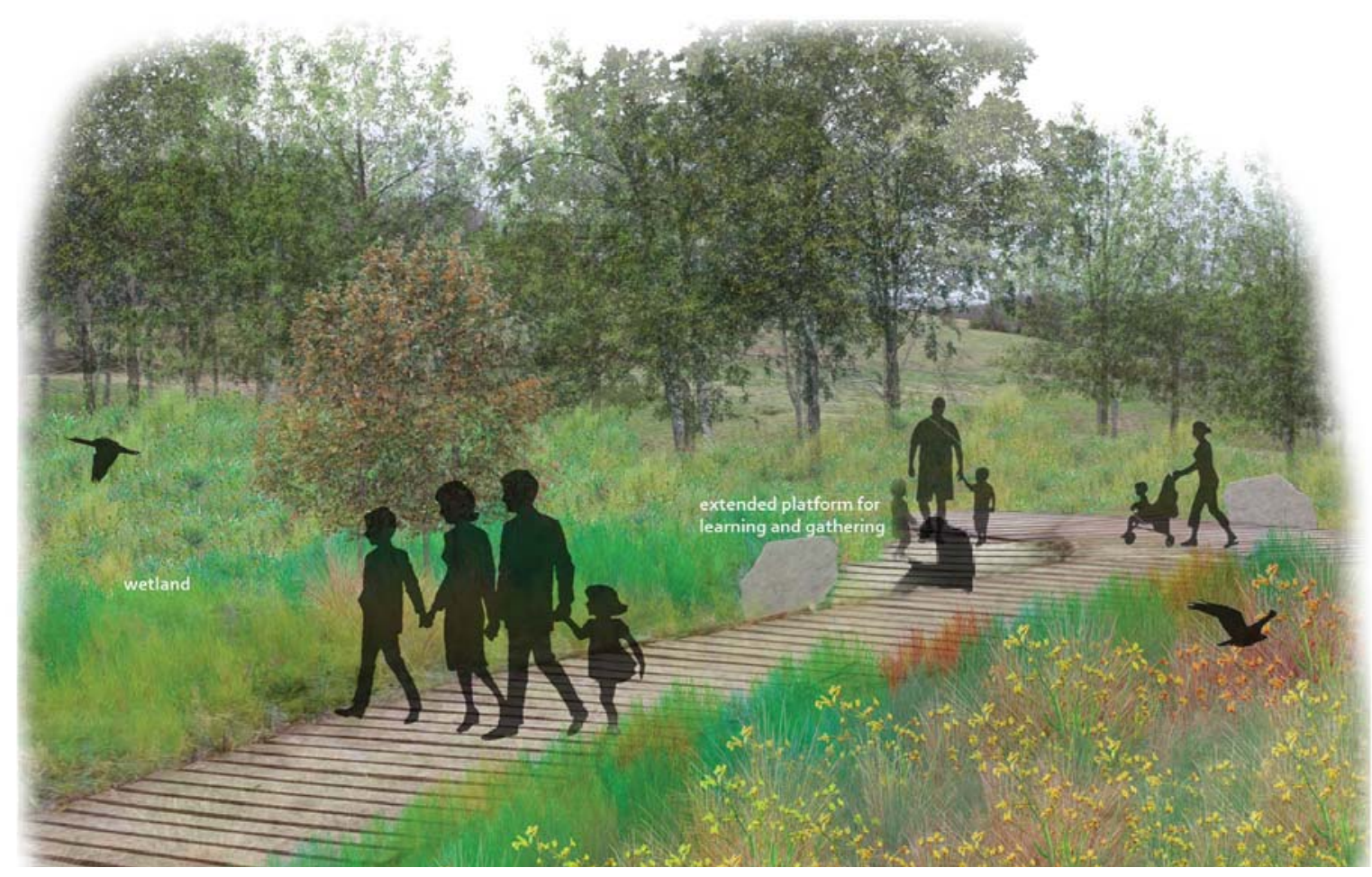


Figure 67. Reference to Figures 66. 68

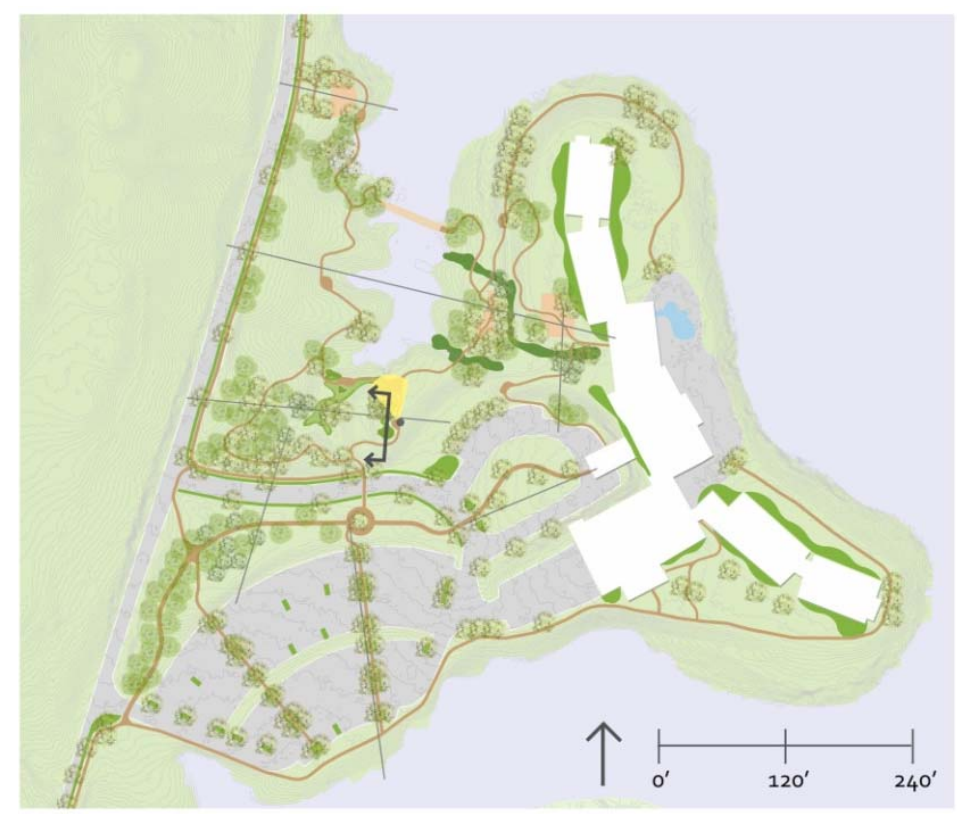

Figure 68. Wetland Exploration Area Cross-Section

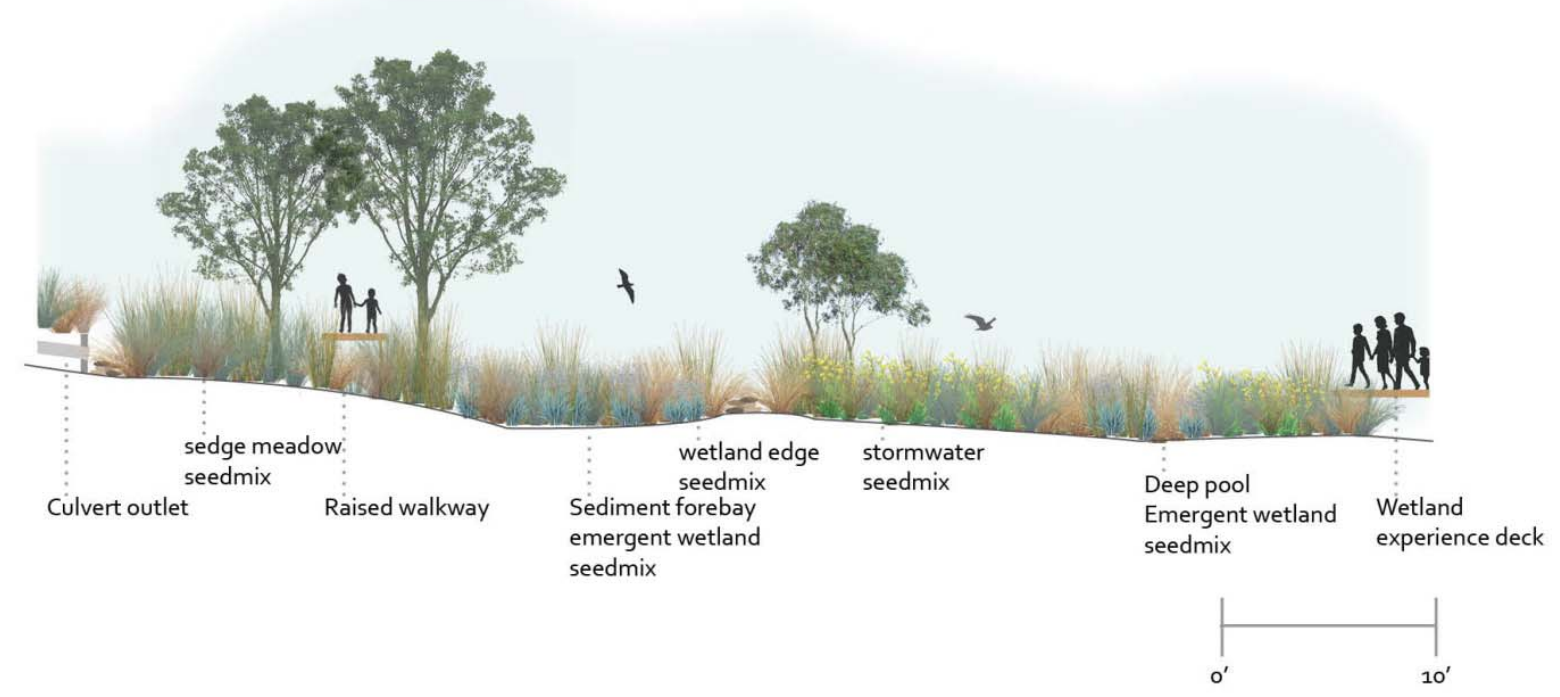

Transitioning away from the wetland, the path splits leading visitors into the forest or through the prairie. The Forest Trail can be accessed beyond the wetland or from the Red Maple Circle path. A display of native West Virginia trees becomes a shaded retreat for exploring and relaxation (Fig. 69, 70). The list of native species includes Acer rubrum, Acer saccharum, 
Fraxinus americana, Liquidambar styraciflua, Carya ovata, Betula papyrifera, and Juglans cinerea. The variety of trees will offer seasonal interest with blooms, fruit and autumn foliage (Shaw and Schmidt, 2003). The steep topography will be stabilized with the trees' deep roots, therefore reducing the erosion and sedimentation in the adjacent wetland (Fig. 71).

Figure 69. Forest Trail

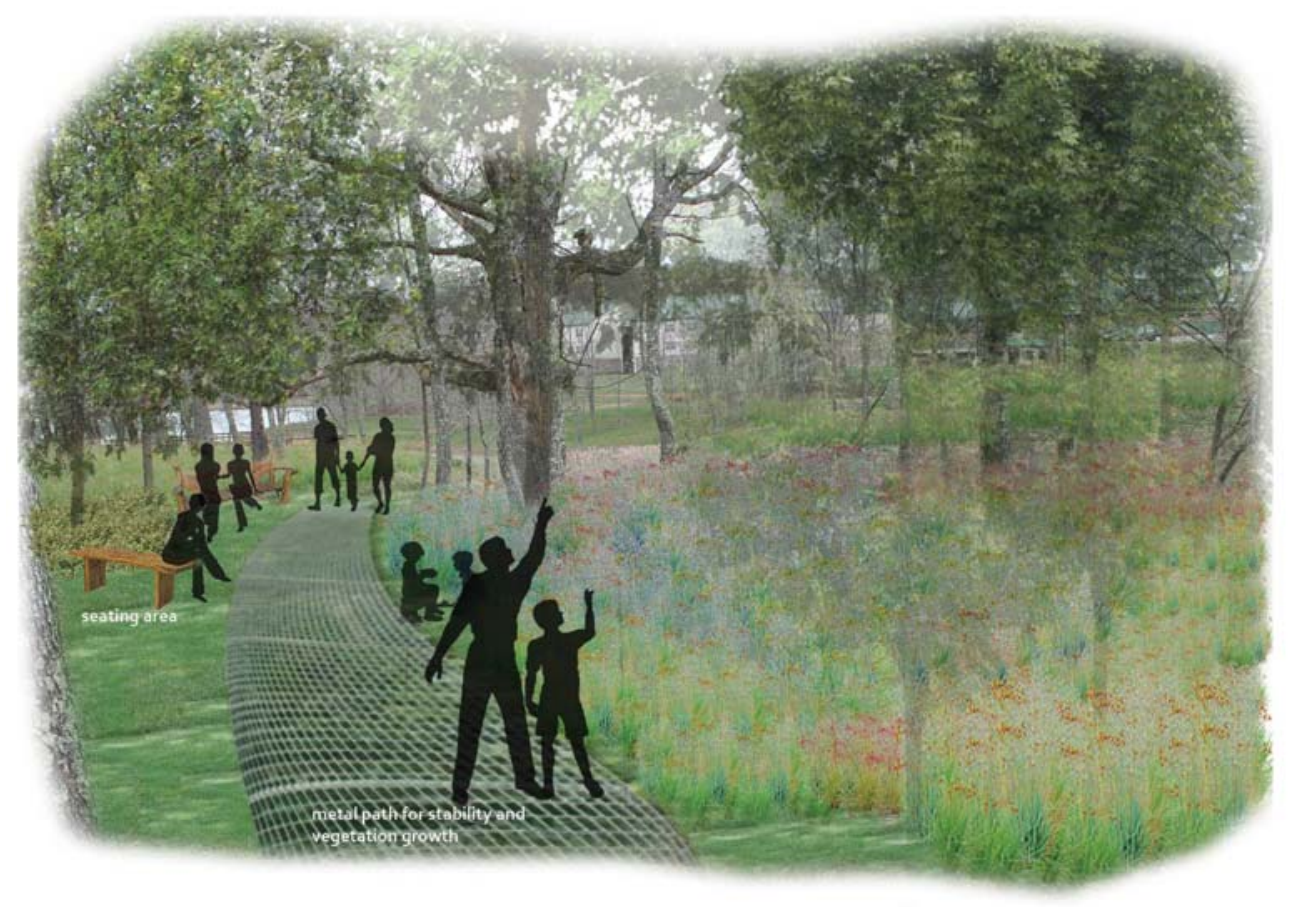

Figure 70. Reference to Figures 69, 71

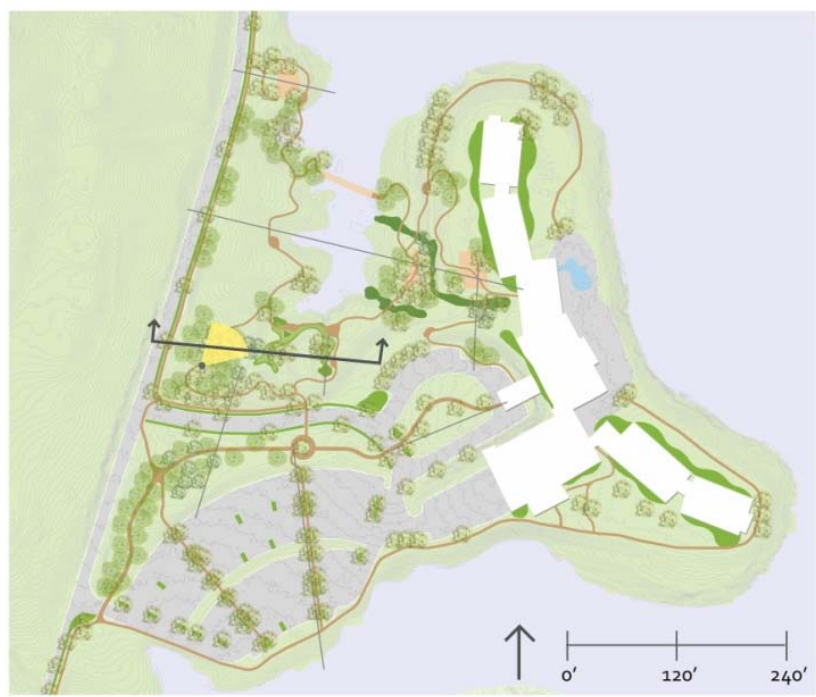


Figure 71. Forest Trail Cross Section

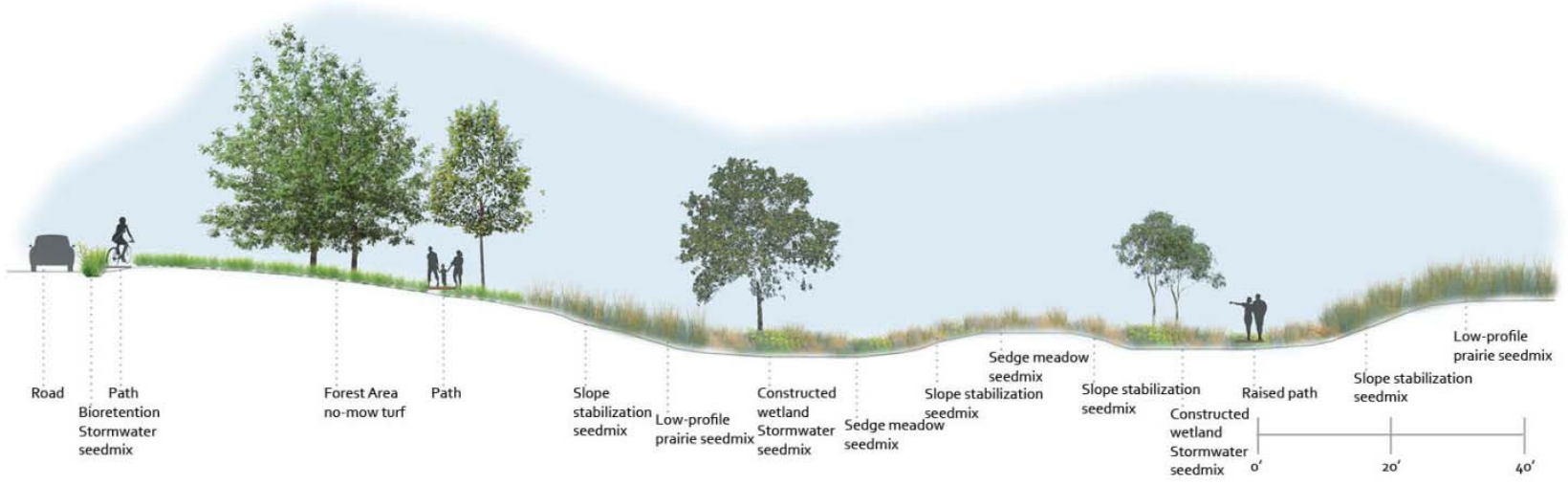

Emerging north out of the forest area, visitors enter the prairie, "an open community dominated by grass”, displaying a range of dry to wet tolerant species on the hillside (Packard and Mutel, 1997) (Fig. 72, 73). The topography and proximity to the lake create a diverse habitat of species within the different growing conditions. Mesic to dry, wet to mesic and sedge meadow seed mixes carry the eye from the road to the lake as groupings weave together (Fig. 74). The variety of grasses and forbs will enhance the existing habitat, becoming a spectacle of birds and insects. The biological diversity not only adds beauty and interest to the park, but also “improves environmental quality, and can foster greater understanding and appreciation of natural communities” (Packard and Mutel, 1997). Additional signature palette species to be planted in the prairie include Schizachyrium scoparium, Calamacrostis canadensis, Andropogan gerardii, Ratibida pinnata, and Liatris spicata. The deep roots of these species will improve soil stability, increase stormwater infiltration and reduce the amount of sedimentation entering the lake (Shaw and Schmidt, 2003). 
Figure 72. Prairie

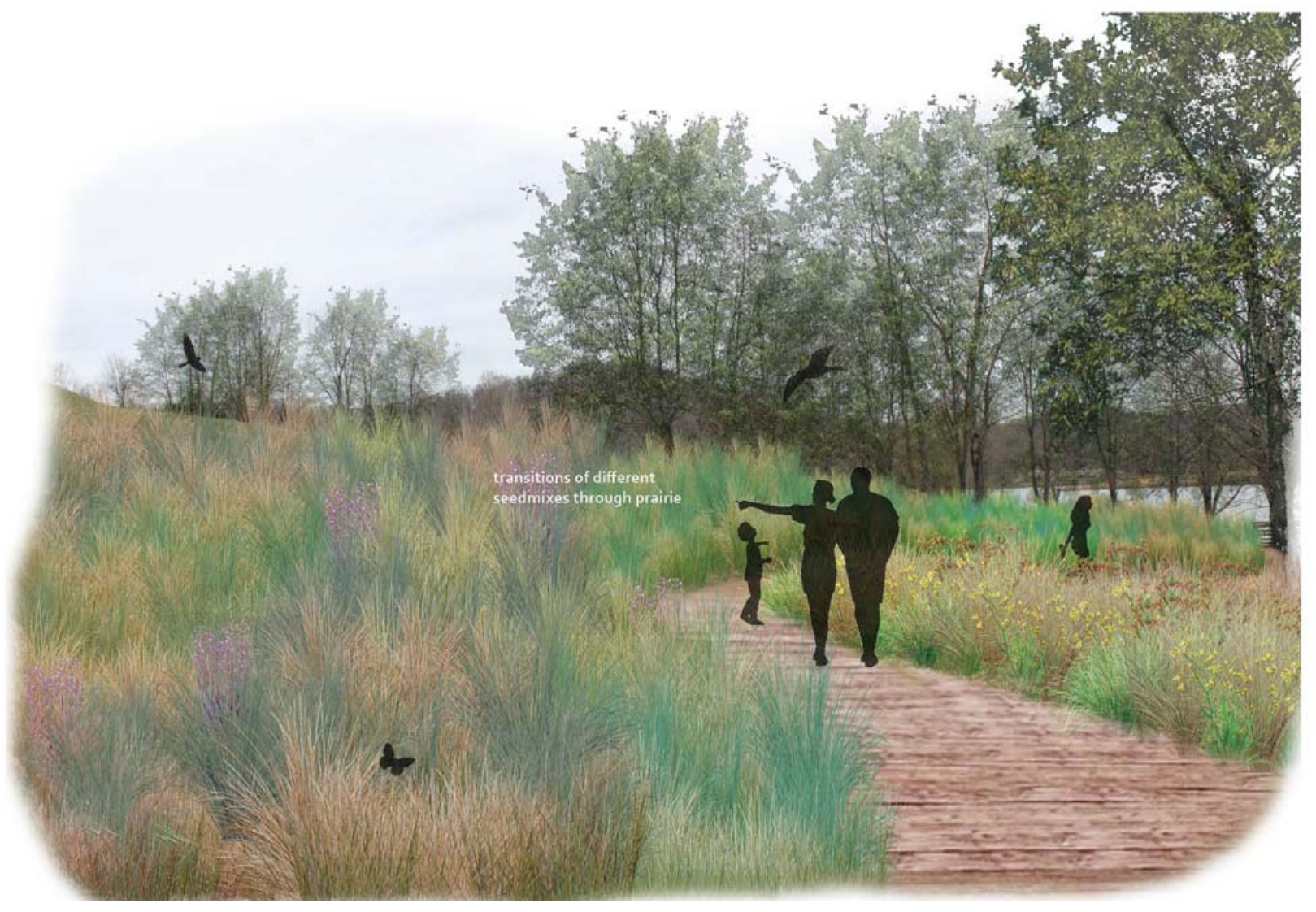

Figure 73. Reference to Figures 72. 74

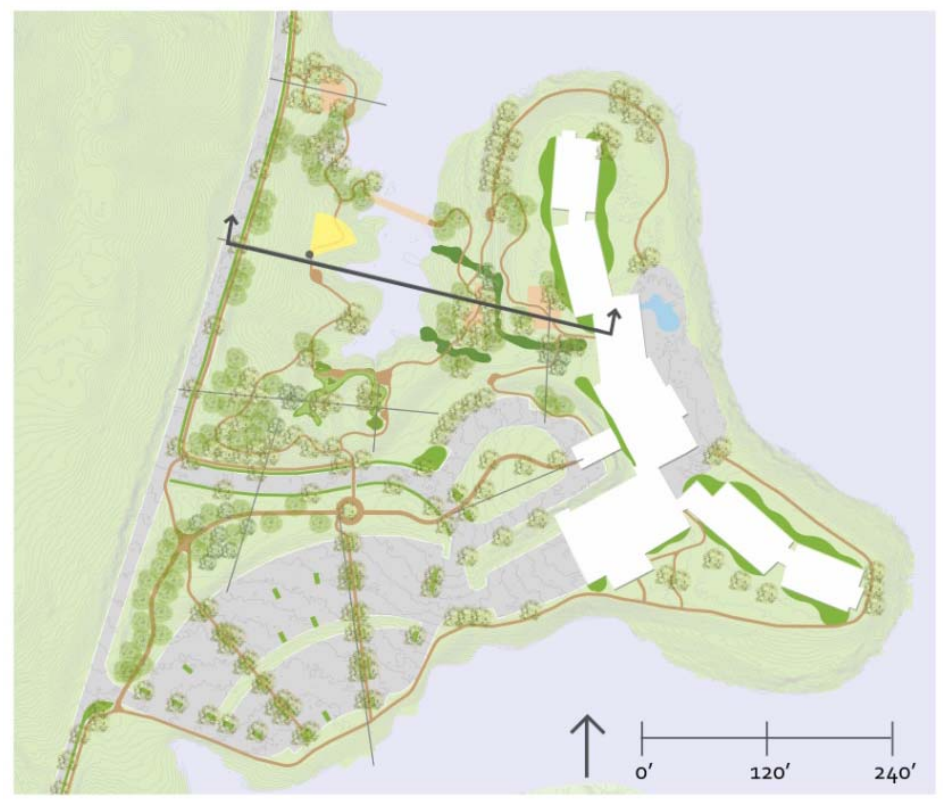


Figure 74. Prairie to Lodge Cross Section

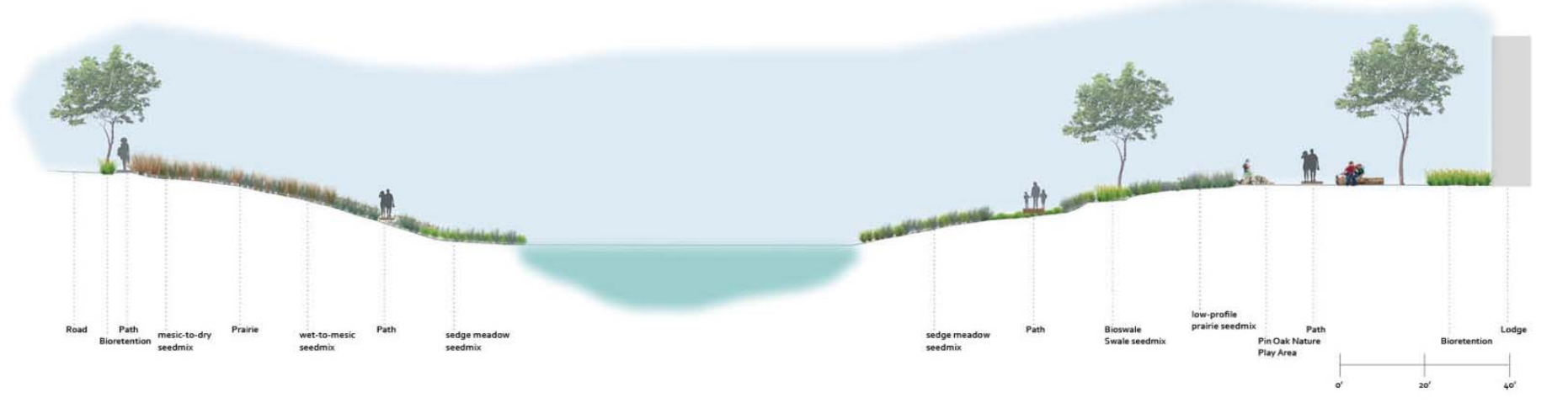

By exiting the prairie and or crossing over the existing bridge, visitors approach the designed canopy bridge (Fig. 75, 76). As a way to conquer the topographic challenge for path designs, an experiential bridge guides visitors through the trees to an overlook of the entire site and out onto the lake before rounding to Dogwood Landing. The bridge resembles the new pedestrian bridge connecting the lodge to the campground; this links the styles from one end of the peninsula to the other. The bridge eventually brings the path back to grade nearing the entrance of Dogwood Landing. This space can be accessed from both the canopy bridge and a gated entrance from the roadside sidewalk. The path from the sidewalk allows guests to enter the entire site from the north as well as providing an access point for small event set-ups (Fig. 77, 78). 
Figure 75. Canopy Bridge

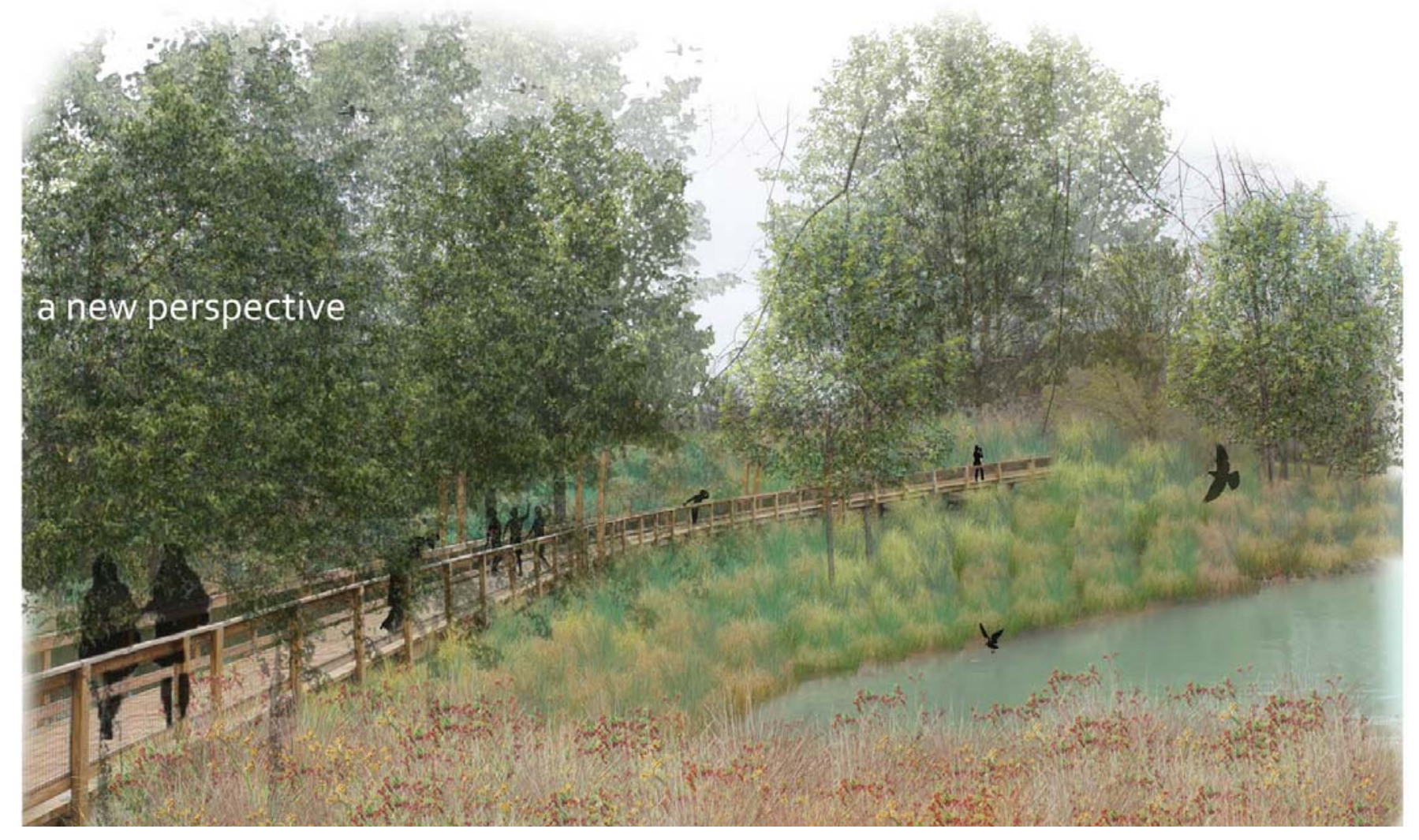

Figure 76. Reference to Figure 75

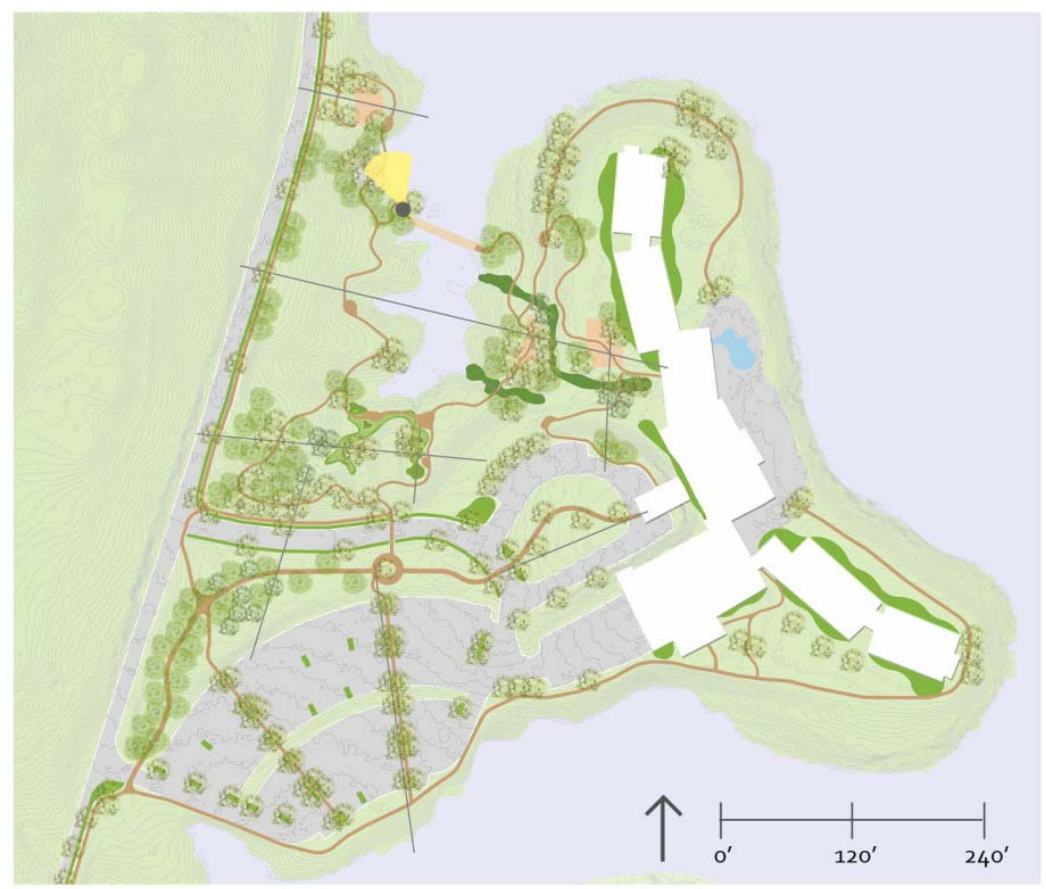


Figure 77. Roadside Entrance to Dogwood Landing

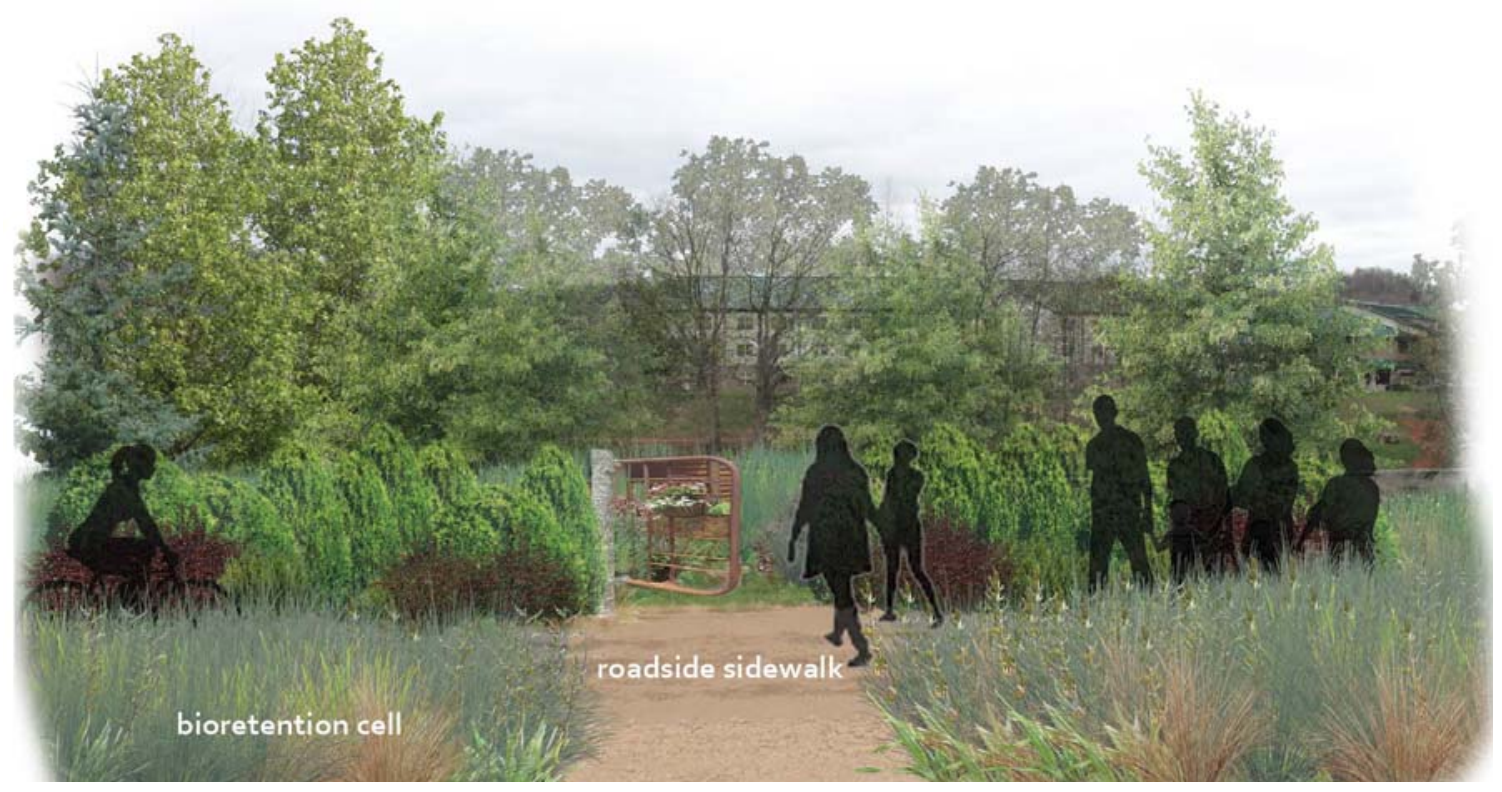

Figure 78. Reference to Figures 77, 79, 80

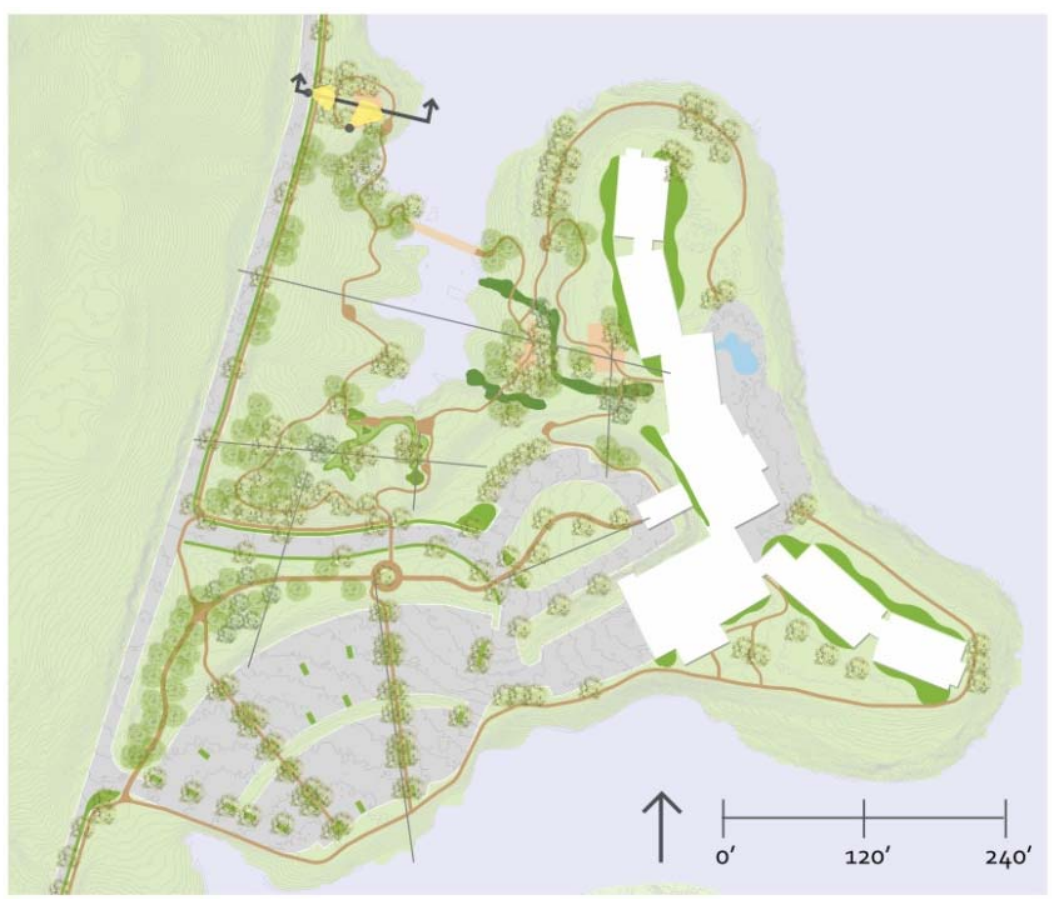

Dogwood Landing provides a small hardscape event space that is framed with a stone seating wall overlooking the lake (Fig. 79). The wall mimics the stone wall at the golf course club house. The deck offers a stable surface for small culinary events, weddings and private 
parties. Cornus florida was selected for its small intimate size and seasonal appeal. Mobile planters create a flexible space where users can shape the open deck for every occasion.

Surrounding the deck towards the road is the dry to mesic prairie seed mix, linking to the prairie area, and the slope stabilization seed mix is designed from the stonewall to the water's edge (Fig. 80). Signature palette shrubs were selected to keep the scale low to emphasize the outstanding view. Viburnum tribolum, Ilex verticillata, and Pycnanthemum virginianum help identify the space and contribute to the seasonal appeal for year-round events. Dogwood Landing enhances the lodge's event space opportunities on site, while also becoming a landmark within the state park for picturesque views of the property.

Figure 79. Dogwood Landing

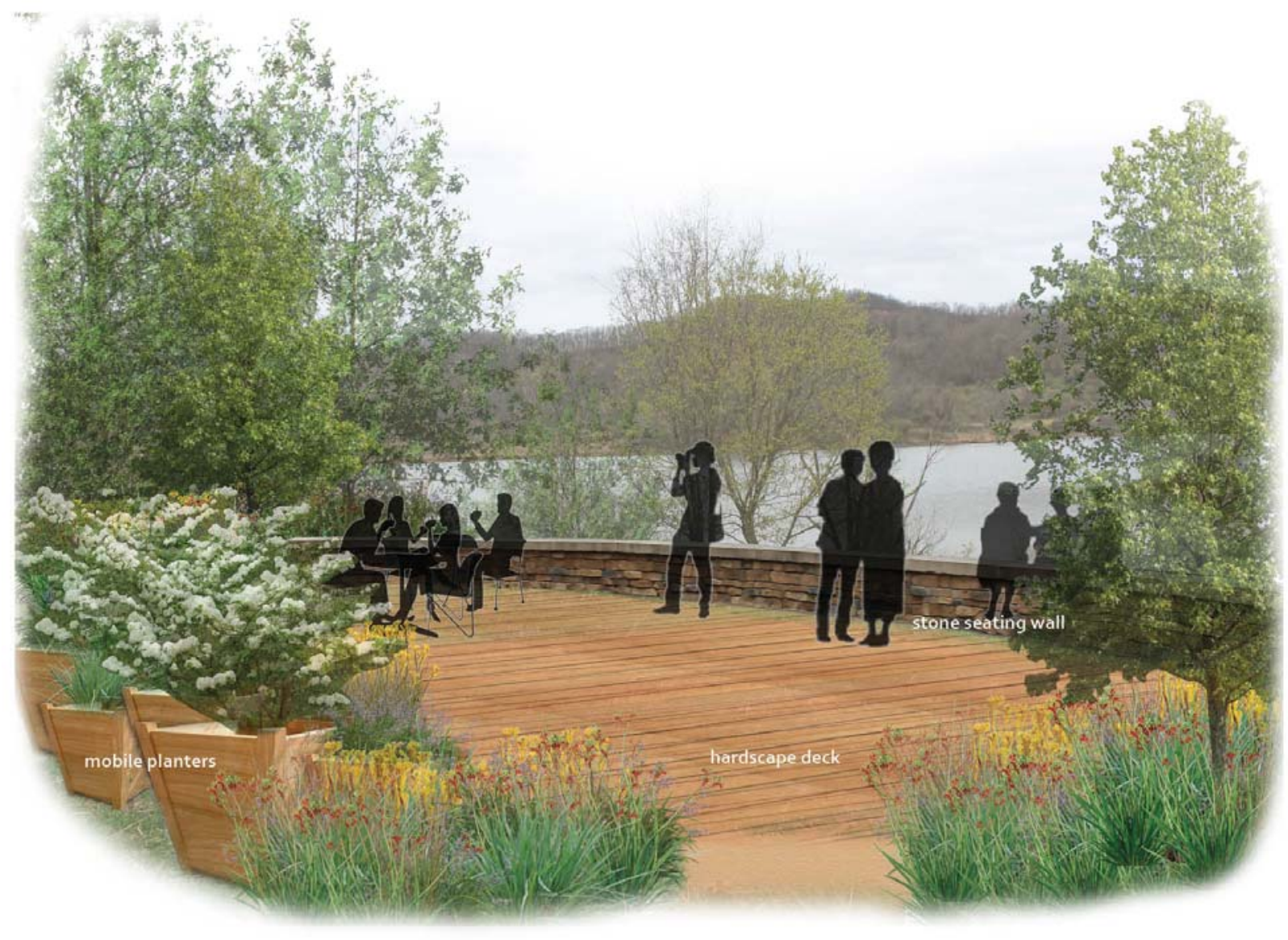


Figure 80. Dogwood Landing Cross-Section

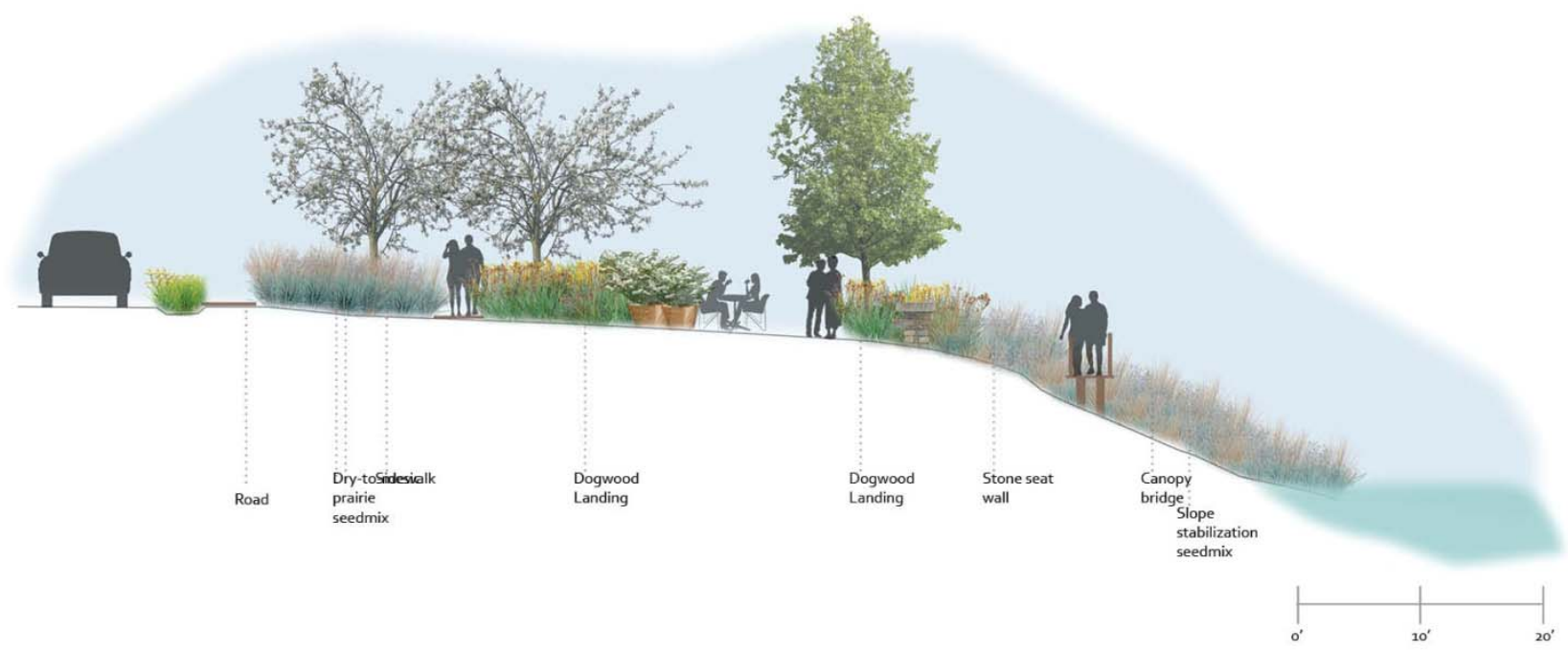

The description of each space completes the journey through the master plan. By

learning about each of the individual spaces, it becomes evident that the stakeholder's wish list was included and expanded upon in the master plan. The native vegetation and socializing spaces were not only an important element to the program but also to the integrity of the state park. The following graphic illustrates the desired program and where each element is designed on site (Fig. 81).

Figure 81. Program Elements Implementation Graphic

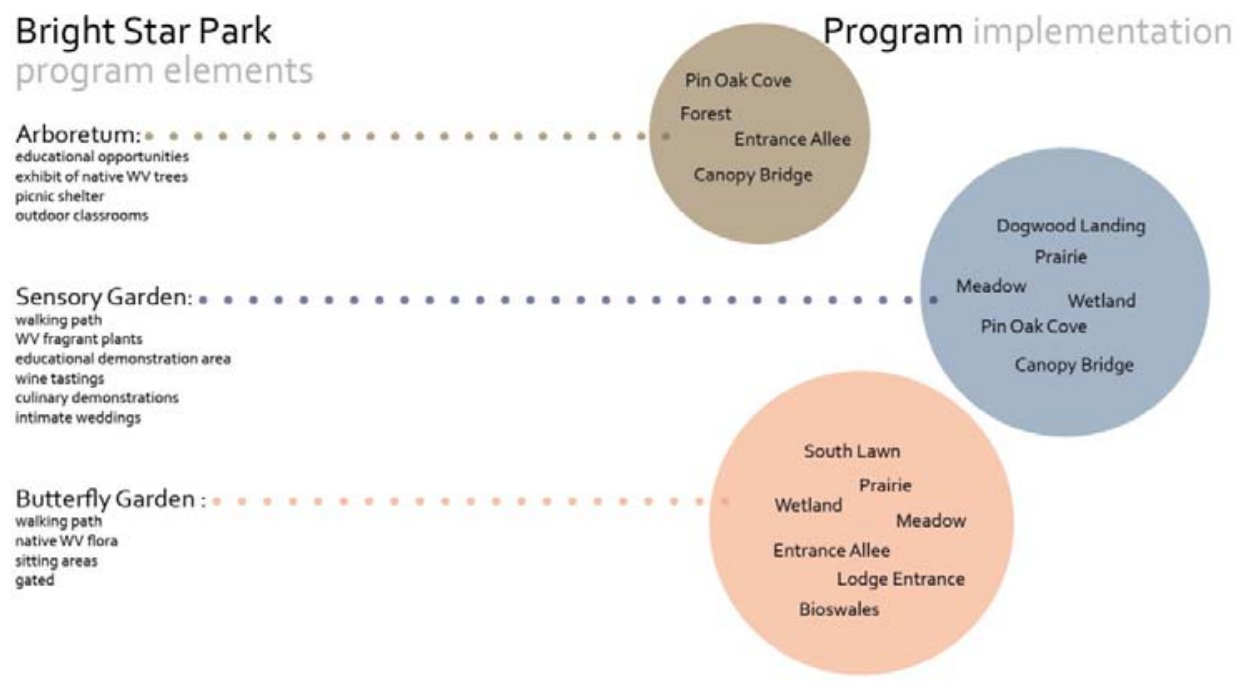


In connection to the design description, a discussion of the Artful Rainwater Design Land Development Amenity Goals will exemplify the application within the project. The seven amenity goals of rain water design include: convenience, education, recreation, safety, social interaction, public relations, and aesthetic richness (Echols, 2008). As seen in the images as well as the specific space descriptions, stormwater management becomes a convenience for visitors as it is linked throughout the entire site. From the edge of the building to the edge of the lake, people can see and experience the rainwater designs. The entire project can be utilized as an educational opportunity, highlighting topics of landscape ecology, native vegetation, hydrology, and the personal experience. The interpretive signage will serve as a foundation for education, and the state park can provide additional educational activities and events within the space. The state park encompasses the concept of recreation, therefore this design must complement that ideal. The design encourages exploration through nature, providing areas to recreate both actively and passively. Safety is a critical design element considering the large number of children users. The dense vegetation creates edges and barriers to the water's edge, therefore keeping children on the designated paths for their safety. Similar to recreation, the design is focused around socializing. Social gathering is not only one of the state park and ARD amenity goals, but also gives reference to the late Roanoke community. Numerous gathering spaces are nestled into the design, lending itself to intimate conversations for relaxation and reflection or large open spaces for group events. The Stonewall State Park Foundation and West Virginia State Parks and Forest Agency both recognize the value of sustainable landscapes and creating experiences within the natural environment. These public relationships demonstrate the stakeholder's ideals and their important influence on the success of this project. The final goal desires aesthetic richness in the stormwater design. The stone cascades, rain chains, and variety 
of vegetation from one stormwater element to the next create a sensual experience that is not only pleasing to the eyes, but to the ears and touch. The aesthetic richness of the stormwater management will evolve with the vegetative growth and the settling of hydrologic patterns (Echols, 2008). Each amenity goal has been addressed and designed throughout the site, bringing attention and experience to stormwater.

\section{CHAPTER 15: Materials}

The primary materials needed for the construction of the design are the elevated trails. Numerous materials exist for raised walkways, including metal, precast concrete and recycled wood plastic. Each material has benefits and unique aesthetic qualities, making one suitable for each space. The precast concrete materials have a fifty to seventy-five year lifespan, and the low maintenance product comes in a variety of colors and textures. The recycled wood plastic materials does not rot, crack or rust, making it nearly maintenance free. The material emits zero toxins, making it a smart environmental decision. The metal paths are slip-resistant, and the holes prevent icing and water pooling which would be beneficial for year round use. The variety of elevated path materials will reduce monotony and keep the interest of the user engaged. The materials will also create another opportunity for interpreting the use of sustainable features in the construction.

As illustrated in the design renderings, the site furnishings for the design are minimal. This was an intentional decision based on the context of the state park and the lodge's need to embrace the natural style. Wood and stone make up the material palette for the site furnishings as they are both found within the state park. West Virginia State Parks create outdoor experiences 
"where people and nature meet”, therefore the materials placed within the parks must maintain the integrity of nature (“West Virginia state”, 2009). 


\section{CHAPTER 16: Construction Documents}

The following details illustrate the technical construction of the built elements on site.

The stone cascades in the bioswales, deck at Dogwood Landing and the stone seating wall are detailed (Fig. 82, 83, 84).

Figure 82. Bioswale Stone Cascade Construction Detail

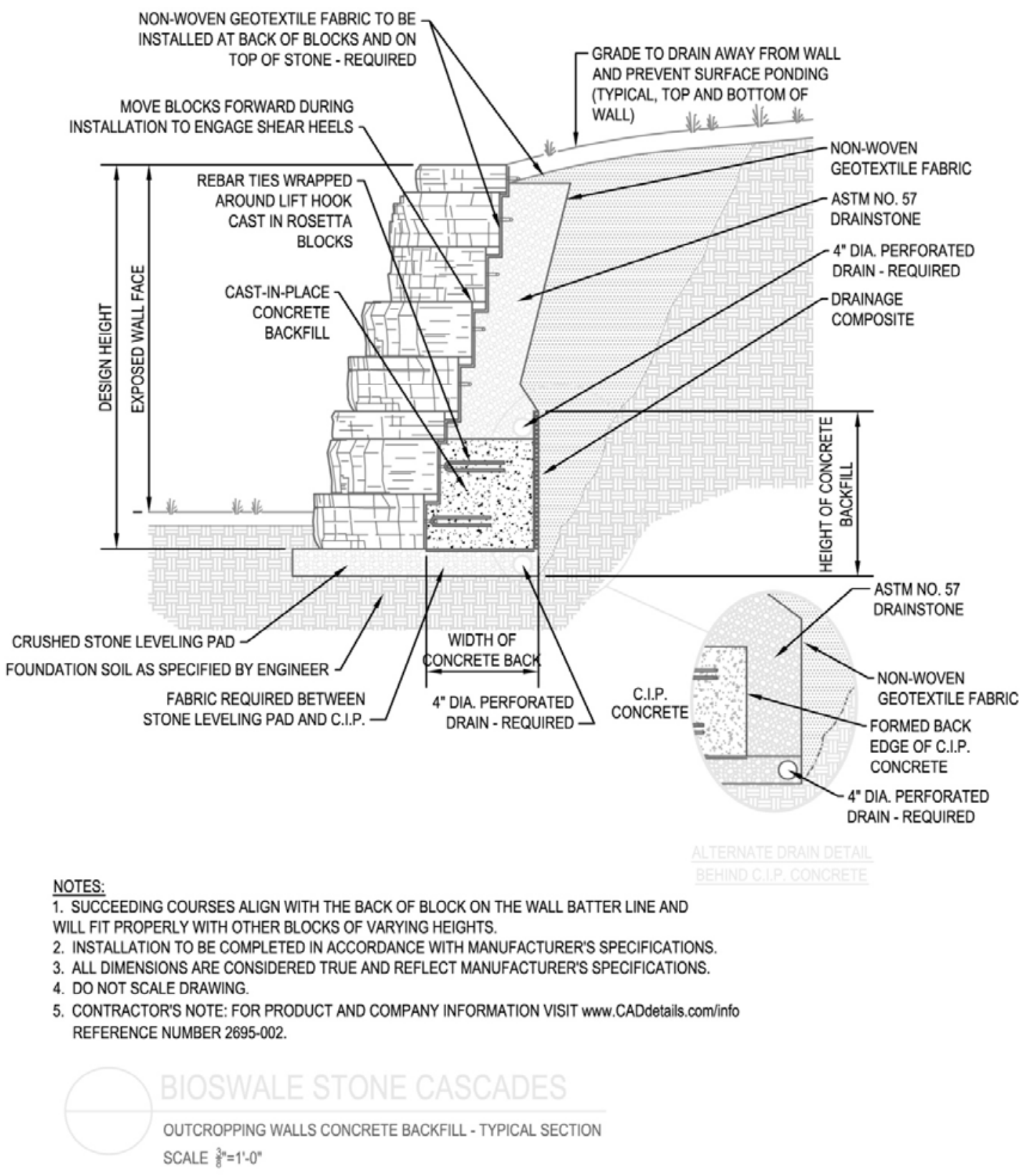


Figure 83. Deck Construction Detail

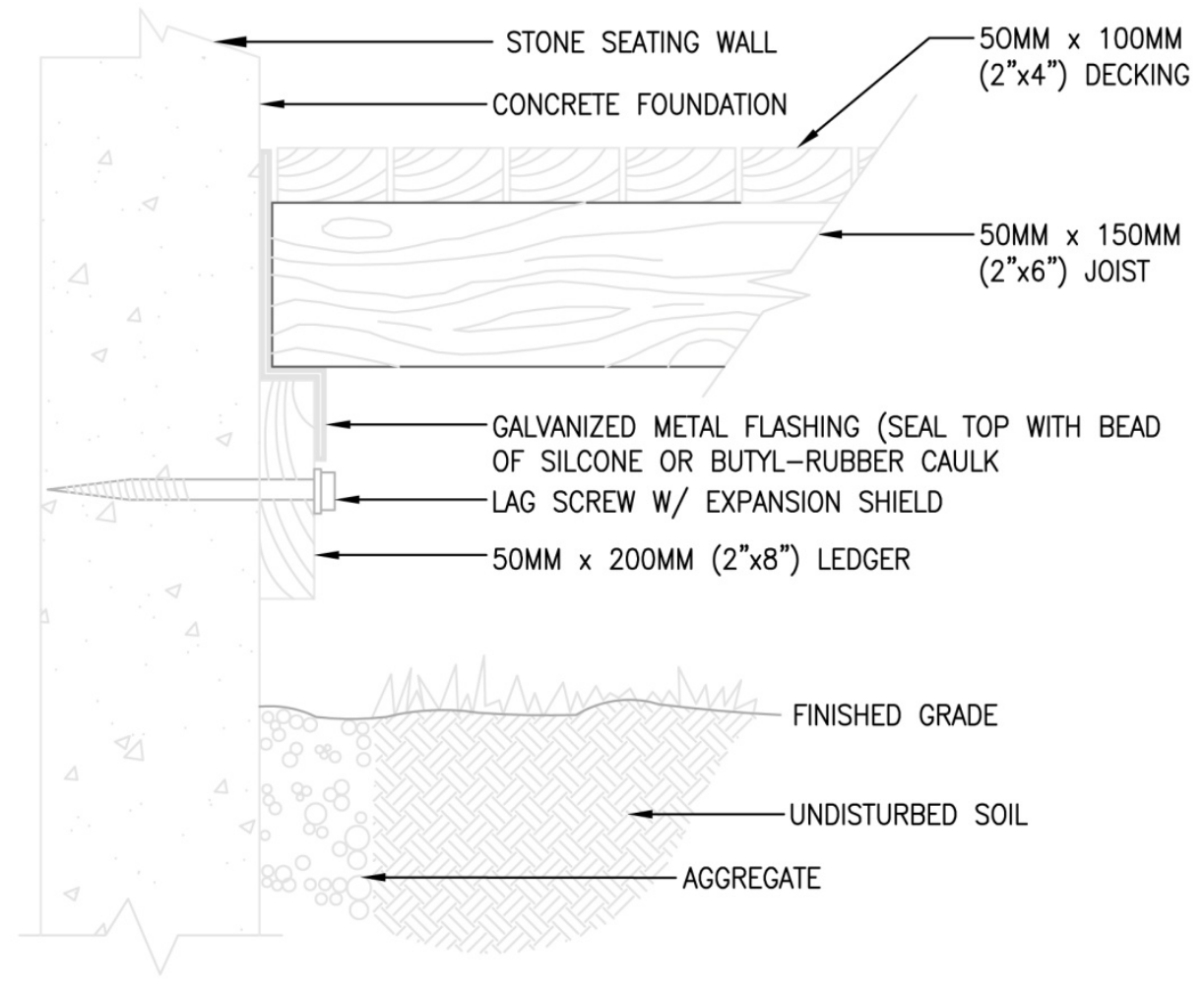

LEDGER TO MASONRY WALL

SCALE $1 "=1 '-0 "$ 
Figure 84. Stone Seat Wall Construction Detail
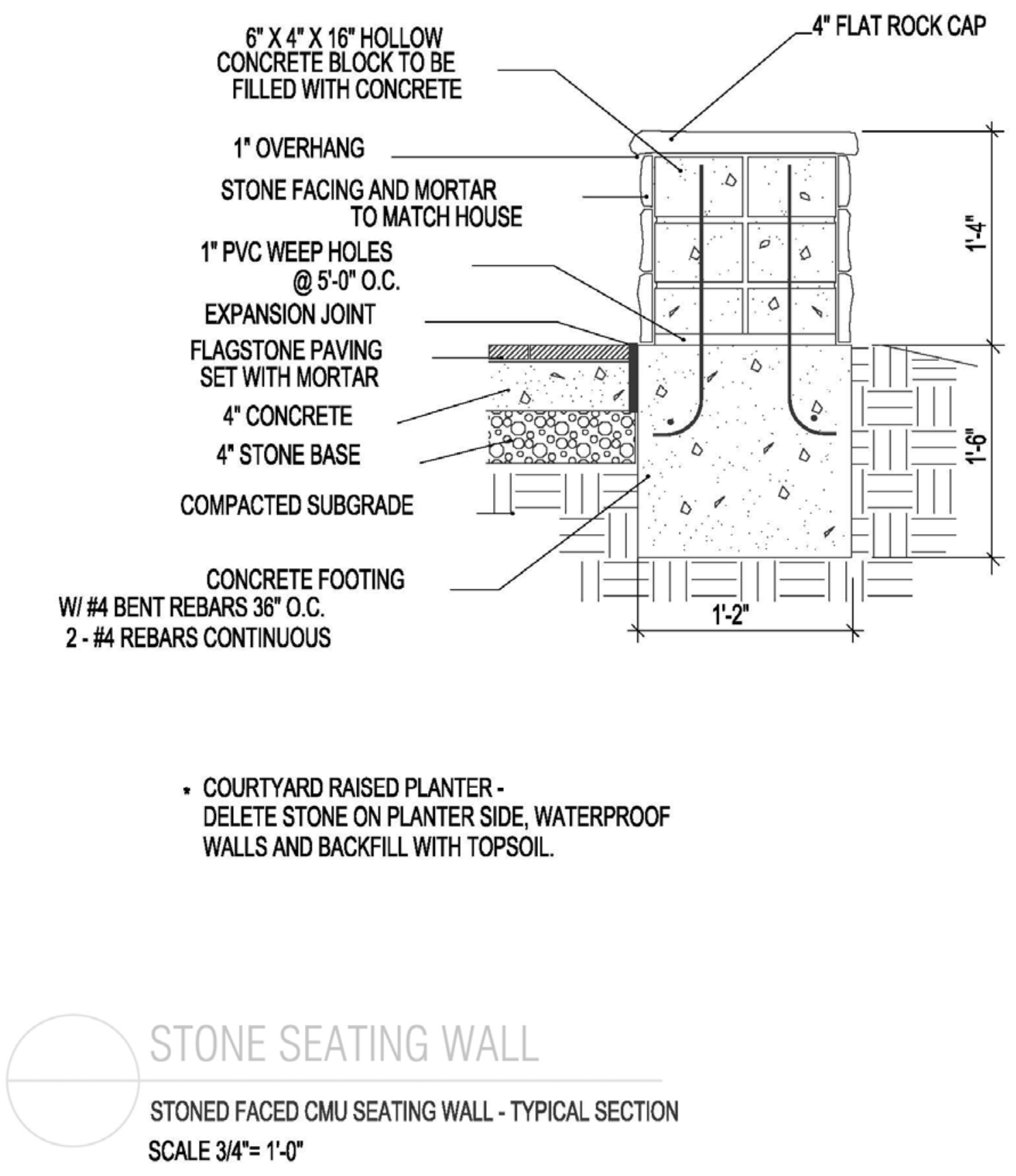


\section{CONCLUSION}

Stonewall Jackson Lake State Park offers not only the opportunity to wander through the iconic Appalachian Mountains of West Virginia, but also the chance to experience the waters of the West Fork River. The park, of just over twenty years, is still forming its identity as development continues to shape the spaces. This project becomes a part of the journey for the state park to demonstrate its ideals and values of the landscape. Interaction with the natural environment is celebrated on a small and intimate scale in this design (Fig. 85). Guests of the lodge, local natives, and visitors of the state park are given the opportunity to not only observe the landscape, but to learn the processes and capabilities of our landscape ecology. Figure 85. Bird’s Eye Site Image

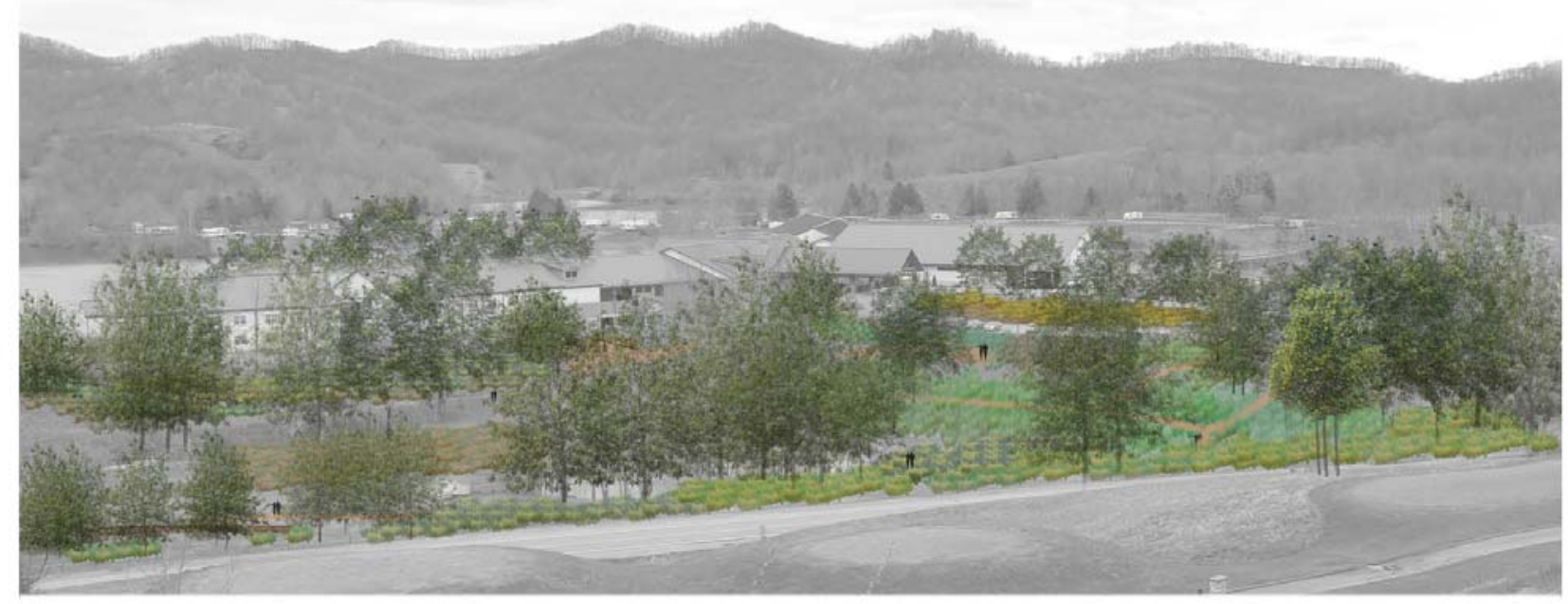




\section{BIBLIOGRAPHY}

Ballestero, T. (2012). University of New Hampshire stormwater center: 2012 biennial report. Informally published manuscript, Stormwater center, Retrieved from http://www.unh.edu/unhsc/sites/unh.edu.unhsc/files/docs/UNHSC.2012Report.10.10.12.p $\underline{\mathrm{df}}$

Campbell, C., \& Ogden, M. (1999). Constructed wetlands in the sustainable landscape. New York, NY: John Wiley \& Sons, Inc.

Carlisle, R.C. U.S. Army Corps of Engineers, Pittsburgh District (1983). Stonewall Jackson Lake West Form River Lewis County, West Virginia. Pittsburgh, PA.

Cook, R.B. (1924). History of Roanoke community. Retrieved from http://www.wvculture.org/history/agrext/roanoke.html.

Dedication. (1988, May 18). The Weston Democrat, pp. 1-52.

Dreiseitl, H. (1999). The role of water in our cities. In A. C. Rowney, P. Stahre \& L. A. Roesner (Eds.), Sustaining Urban Water Resources in the 21st Century Reston, VA: American Society of Civil Engineers.

Dreiseitl, H., \& Grau, D. (2005). New waterscapes: Planning, building and designing with water. Basel, Switzerland: Birkhauser Publishers for Architecture.

Echols, S., \& Pennypacker, E. (2008). From Stormwater Management to Artful Rainwater Design. Landscape Journal, 27(2), 268-290.

Galatowitsch, S., \& van der Valk, A. (1998). Restoring prairie wetlands: An ecological approach. Ames, IA: Iowa State University Press.

History and facts. (2012). Retrieved from http://www.stonewallresort.com/about_the_resort/history_facts/.

Kaplan, R., Kaplan, S., \& Ryan, R. (1998). With people in mind: Design and management of everyday nature. Washington, DC: Island Press.

Maryland Department of the Environment, (2009). Maryland stormwater design manual. Retrieved from MDE website: http://www.mde.state.md.us/programs/Water/StormwaterManagementProgram/Maryland StormwaterDesignManual/Pages/programs/waterprograms/sedimentandstormwater/storm water_design/index.aspx

Nassauer, J. (1995). Messy ecosystems, orderly frames. In S. Swaffield (Ed), Theory in Landscape Architecture. Philadelphia, PA: University of Pennsylvania Press. 
Packard, S., \& Mutel, C. (1997). The tallgrass restoration handbook: For prairies, savannas and woodlands. Washington, D.C.: Island Press.

Portland Bureau of Environmental Services, (2008). Stormwater manual. Retrieved from City of Portland, Oregon website: http://www.portlandonline.com/bes/index.cfm?c=47954

Sasaki, H. (1950). Design process. In S. Swaffield (Ed.), Theory in Landscape Architecture Philadelphia, PA: University of Pennsylvania Press.

Shaw, D., \& Schmidt, R. (2003). Plants for stormwater design: Species selection for the Upper Midwest. St. Paul, MN: Minnesota Pollution Control Agency.

Sipes, J. (2010). Sustainable solutions for water resources: Policies, planning, design and implementation. New York, NY: John Wiley \& Sons, Inc.

Smith, E.C. (1920). A history of Lewis County, West Virginia. Weston, WV: Edward C. Smith.

Stahre, P. (2008). Blue-green fingerprints in the city of Malmö, Sweden. Malmö, Sweden: VA SYD.

Stonewall state park foundation . (n.d.). Retrieved from:

http://www.stonewallstateparkfoundation.org/index.html.

Sustainable sites. (2013). Retrieved from http://www.cardnojfnew.com/.

Tunney, K. W. (2000, December 31). Innovative stormwater design: The role of the landscape architect. Stormwater magazine, Retrieved from http://www.erosioncontrol.biz/SW/Articles/Innovative_Stormwater_Design_The_Role_o f the_Lands_3259.aspx?

U.S. Environmental Protection Agency. (2012, October 25). Low impact development (LID). Retrieved from http://water.epa.gov/polwaste/green/index.cfm

U.S. Environmental Protection Agency, Office of Water (2000). Low impact development (LID): A literature review (EPA-841-B-00-005). Washington, DC: U.S. EPA

Virginia DCR Stormwater , (2011). Bioretention . Retrieved from website: http://chesapeakestormwater.net/2012/03/design-specification-no-9-bioretention/ 
Virginia DCR Stormwater , (2011). Constructed wetlands. Retrieved from website: http://chesapeakestormwater.net/2012/03/design-specification-no-13-constructedwetlands/

West Virginia state parks and forests. (2009). Retrieved from http://www.wvstateparks.com/Parks_History.htm 